\title{
DEATHS OF NUMEROUS AT RANA PLAZA: DOES LIABILITY REST ELEVEN THOUSAND KILOMETERS AWAY?
}

\author{
AUTHOR: SAKIF ALAM \\ A THESIS SUBMITTED TO \\ THE FACULTY OF GRADUATE AND POSTDOCTORAL AFFAIRS \\ IN PARTIAL FULFILLMENT OF THE \\ REQUIREMENTS FOR THE DEGREE OF \\ MASTER OF ARTS \\ IN \\ LEGAL STUDIES \\ CARLETON UNIVERSITY \\ OTTAWA, ON \\ (C) 2016 \\ SAKIF ALAM
}




\begin{abstract}
Since 1977, Bangladesh's garment industry has consistently grown, but is marred by factory fires and collapses. Of the greatest magnitude is the collapse of Rana Plaza - a locally owned building that collapsed on 24 April 2013, killing 1,134 persons and injuring more than 2,500. Since Rana Plaza fabricated garments for Loblaw Companies Limited, a corporation incorporated in Ontario, Canada, I ask whether Loblaw can be held accountable. Using enterprise theory and the Supreme Court of Canada's decision in Bazley v Curry, I argue that Loblaw introduced an enterprise into the community carrying certain inherent risks. Since those risks ripened into harm, Loblaw ought to be held liable. This research speaks to the wider conversation between entity law and enterprise theory and can be situated within the broader ongoing debate between the law's ability to accord protection to corporations and its inability to protect those from corporate misconduct.
\end{abstract}




\section{PREFACE}

This Thesis is an original intellectual product of the author, Sakif Alam. Throughout the project, the use of the words he or his does not only denote the male gender, but is used to refer to the genders of both male and female persons. 


\section{ACKNOWLEDGEMENTS}

I would not have been able to complete this Thesis without the unwavering support of my family — Brigadier General Zahur-ul Alam (Father), Anju Alam (Mother), and Ariq Alam (Brother). Everyday, I gave up writing this Thesis, and everyday you helped me realize that I should continue. I did, and it is because of the three of you. I can never overemphasize your importance in my life. Thank you for all that you have done and continue to do without question. You truly are my everything.

For this Thesis, I was co-supervised. Dr. Dale Spencer, I thank you for your guidance (literally), positive words, and our conversations. I would also like to thank Dr. Betina Kuzmarov. You were tremendously patient and guided this project in the direction it needed. To the both of you, I felt as if you believed I could complete this project even when I did not. If I had not received your support, this project would have remained incomplete and we are well cognizant of this fact.

Dr. Alberto Salazar, who has been of immeasurable assistance as my Second Reader, thank you. Your knowledge on corporate law was only surpassed by your kindness. I wish to also convey my gratitude to Dr. Howard Nemiroff, who served as the External Member in my committee. I am of the opinion that it was your presence and contribution that made my Thesis Defense all the more lively. 


\section{TABLE OF CONTENTS}

$\begin{array}{ll}\text { ABSTRACT } & \text { ii }\end{array}$

$\begin{array}{lll}\text { PREFACE } & \text { iii }\end{array}$

ACKNOWLEDGEMENTS iv

TABLE OF CONTENTS N V

\begin{tabular}{l|c|} 
ABBREVIATIONS & $\mathrm{x}$
\end{tabular}

$\begin{array}{ll}\text { I - INTRODUCTION } & 1\end{array}$

A - THEORETICAL FRAMEWORK 4

i. $\quad$ The Theory of Enterprise Liability 8

ii. Summary of Arguments 9

B - NOTES ON TERMINOLOGY 10

i. $\quad$ Manufacturer \& Supplier $\quad 10$

ii. Rana Plaza \& New Wave $\quad 11$

$\mathrm{C}$ - IMPORTANCE OF RESEARCH \& GAP IN KNOWLEDGE 11

D - METHODOLOGY \& CHAPTER OUTLINES 14

$\begin{array}{ll}\text { E - DELIMITATIONS } & 17\end{array}$

i. Why Only Loblaw and Not Hold Other Corporations Liable? 18

ii. The United States has Cordoned its Courts 18

iii. What if Litigation Against Loblaw Fails? 19

iv. Recent Statutory Developments 19

v. Omission in Discussing the Government of Bangladesh 20

II - GEOGRAPHICAL BARRIERS ARE ONLY SEEN IN CARTOGRAPHY 21

A — FOUNDATIONAL TENET FOR INTERNATIONAL TRADE 21

i. Collaborative Reductions in Barriers to Trade 22 
ii. International Monetary Fund, World Bank,

$\&$ the World Trade Organization

B - FALL OF BARRIERS IS TO THE RISE OF MULTINATIONAL 25

ENTERPRISES

i. The Economic Reasons for the Growth of Multinational 27

Enterprises

ii. Integrated Supply Chains 28

iii. The Legal Reasons for the Growth of Multinational Enterprises 29

iv. Globalization's Effects on Multinational Enterprises 30

$\begin{array}{ll}\text { v. Branding } & 31\end{array}$

vi. Neoliberalism: Political Apparatus of Globalization 32

C - HISTORY OF BANGLADESH'S RISE IN GARMENT PRODUCTION 35

i. $\quad$ Contribution of the Government of Bangladesh 37

ii. An Insurmountable International Predicament 38

iii. A Mentionable Transformation 40

iv. Women Empowerment 41

v. Bangladesh's Garment Sector will Further Grow 41

vi. Bangladesh has the Ingredients Corporations Desire 43

D — WILL GLOBALIZATION PERSIST? 43

E - RESEARCH IMPLICATIONS 45

III - WHY INTERNATIONAL LAW DOES NOT SUFFICE 49

A — DOMESTIC LAW, INTERNATIONAL LAW \& THE REGULATION $\quad 50$

OF MULTINATIONAL ENTERPRISES

B - HARD LAW \& SOFT LAW 52

i. Core International Human Rights Instruments 53

i.1 - International Labour Organization 54

i.2 - OECD Guidelines for Multinational Enterprises $\quad 56$

i.3 - ILO Tripartite Declaration 57

i.4 - UN Global Compact 57

i.5 — UN Guiding Principles on Business and 57

Human Rights

ii. Corporate Social Responsibility $\quad 59$

iii. Voluntary Codes 61 
C - THE DISTINCT LEGAL PERSONS: ENTITY LAW \&

LIMITED LIABILITY

i. $\quad$ Lack of Separate Independent Identity 67

ii. Agency Relationship 68

iii. Provision by Statute 68

D - THE ENTERPRISE SOLUTION 72

i. What Once was Should Probably Not Dictate the Future 73

ii. What Hudbay Said 75

E - RESEARCH IMPLICATIONS 76

IV - THE MERGER OF LINKED CONNECTION 77

$\begin{array}{ll}\text { A - THE BAZLEY DECISION } & 77\end{array}$

i. Guidelines from Bazley $\quad 78$

ii. Vicarious Liability $\quad 79$

ii.1 - Just \& Practical Remedy $\quad 80$

ii.2 - Deterrence of Future Harm 81

iii. Principles of Enterprise in Vicarious Liability 81

B - INDEPENDENT CONTRACTORS 82

$\begin{array}{ll}\mathrm{C} \text { - NEGLIGENCE AT RANA PLAZA } & 84\end{array}$

i. Injury to the Plaintiff and the Duty of Care Owed 85 by the Defendant

ii. Was there a Breach in the Standard of Care? 87

ii. 1 - Factors to be Considered 87

ii.2 - Was there a Recognizable Risk of Injury? 89

ii.2.1 - Can the Potential Loss be Outweighed 90

by the Utility of the Defendant's Conduct?

ii.2.2 - Would the Cost of Removing the Risk 91

have been Unconscionably High?

iii. Is the Loss Suffered Caused by the Conduct of the Defendant? 92

iv. Contributory Negligence on the Part of Claimants 94

Barring Recovery 
iv. 1 - The Poorest are Working at Garment Factories

D - IS LOBLAW \& RANA PLAZA INVOLVED IN ONE

98

ECONOMIC ENTERPRISE?

i. Level of Knowledge \& the Protective Shield of Subcontracting 99

ii. How Bureau Veritas Pierces the Shield of Liability 100 as Set by the Subcontract

$\begin{array}{ll}\text { iii. Contract of Service } & 101\end{array}$

iv. Degree of Control \& the Commonality of Enterprise 102

iv.1 - An Employment Relationship without a 103 Formal Employment Relationship?

iv.2 - Loblaw Had the Option of Selecting 104 Another Supplier

iv.3 - Importing the Hudbay Guidelines 105

iv.4 - Work at New Wave was Integral to Loblaw 106

iv.5 - Loblaw's Profits Derived from the 107 Labor of New Wave

$\begin{array}{ll}\text { v. Creation and Exacerbation of Risk } & 108\end{array}$

v.1 - If BRAC were Closed, Why was New Wave Not? 109

v.2 - Worldwide Responsible Accredited Production $\quad 110$

v.3 - Was the Risk Inherent in the Enterprise? 111

vi. Negligence Part of Scope of Employment? 113

E - POLICY RATIONALES OF HOLDING LOBLAW 113

VICARIOUSLY LIABLE

i. Just \& Practical Remedy $\quad 114$

ii. Deterrence 116

$\begin{array}{ll}\text { F - CONCLUDING COMMENTARY } & 119\end{array}$

$\begin{array}{ll}\mathrm{V}-\mathrm{CONCLUSION} & 122\end{array}$

$\begin{array}{ll}\text { A - SUMMARY } & 122\end{array}$

$\begin{array}{ll}\text { i. A Brief Clarification } & 125\end{array}$

B - RECOMMENDATION 125

i. International Board for Corporate Governance 125

$\begin{array}{ll}\text { ii. } & \text { Lack of a Canadian Statute } \\ & 127\end{array}$ 
REFERENCES

LEGISLATION

CASE LAW

SECONDARY MATERIAL: BOOKS 


\begin{tabular}{|c|c|}
\hline \multicolumn{2}{|c|}{ ABBREVIATIONS } \\
\hline Accord & $\begin{array}{l}\text { Accord on Fire and Building Safety } \\
\text { in Bangladesh }\end{array}$ \\
\hline Alliance & $\begin{array}{l}\text { Alliance for Bangladesh Worker } \\
\text { Safety }\end{array}$ \\
\hline$A T C$ & Agreement on Textiles and Clothing \\
\hline CCTC & $\begin{array}{l}\text { Code of Conduct for Transnational } \\
\text { Corporations }\end{array}$ \\
\hline CSR & Corporate social responsibility \\
\hline$E B A$ & Everything but Arms \\
\hline $\mathrm{EPZ}$ & Export Processing Zone \\
\hline FDI & Foreign direct investment \\
\hline$G A T T$ & $\begin{array}{l}\text { General Agreement on Tariffs and } \\
\text { Trade }\end{array}$ \\
\hline GOB & Government of Bangladesh \\
\hline IBCG & $\begin{array}{l}\text { International Board for Corporate } \\
\text { Governance }\end{array}$ \\
\hline$I C C P R$ & $\begin{array}{l}\text { International Covenant on Civil and } \\
\text { Political Rights }\end{array}$ \\
\hline$I C E S C R$ & $\begin{array}{l}\text { International Covenant on } \\
\text { Economic, Social and Cultural } \\
\text { Rights }\end{array}$ \\
\hline ILO & International Labour Organization \\
\hline ILO Tripartite Declaration & $\begin{array}{l}\text { International Labour Organization } \\
\text { Tripartite Declaration on Principles } \\
\text { Concerning Multinational } \\
\text { Enterprises and Social Policy }\end{array}$ \\
\hline
\end{tabular}


IMF

ITO

LCL/Loblaw

MFA

MNE

OECD Guidelines

PGI

RMG

RPCC

SCC

UN

UN Guiding Principles

World Bank

WRAP

WTO

WTO Agreement
International Monetary Fund

International Trade Organization

Loblaw Companies Limited

Multi-Fiber Arrangement

Multinational enterprise

Organization for Economic Cooperation and Development Guidelines for Multinational

Enterprises

Pearl Global Industries

Readymade garments

Rana Plaza Coordination Committee

Supreme Court of Canada

United Nations

United Nations Guiding Principles on Business and Human Rights

The World Bank consists of two institutions: The International Bank for Reconstruction and Development and the International Development Association. I refer to them collectively as the "World Bank."

Worldwide Responsible Accredited Production

World Trade Organization

Marrakesh Agreement Establishing the World Trade Organization 


\section{I - INTRODUCTION}

"The harsh fact of life is that nobody does anything until a lot of lives are lost."

— Dr. Dan Kirkwood ${ }^{1}$

On 24 April 2013, Rana Plaza, a locally owned building in Bangladesh, collapsed, killing

1,134 persons and injuring more than $2,500 .^{2}$ The magnitude of the collapse, which has been

termed "mass industrial homicide," has made Rana Plaza the deadliest structural failure in the

history of the world's garment industry. ${ }^{3}$ The facility housed garment factories that were

fabricating garments for, inter alia, United Colors of Benetton, Mango, Loblaw Companies

Limited (hereinafter "LCL"), Primark, El Corte Inglés, and Walmart for the purposes of

exportation. ${ }^{4}$ In response to the collapse, though the Walt Disney Company did not source from

Rana Plaza, it chose to stop placing orders in Bangladesh. ${ }^{5}$ Other companies, however, have tried

a different approach.

A number of European manufacturers have signed the Accord on Fire and Building Safety

in Bangladesh (hereinafter "Accord"). ${ }^{6}$ The Accord is a legally binding five-year agreement

${ }^{1}$ Laureen Snider, “Cooperative Models and Corporate Crime: Panacea or Cop-Out?" (1990) 36 Crime \&

Delinquency 373 at 373; Dr. Kirkwood's statement was said in reference to the Piper Alpha explosion that killed 166 individuals, at 387.

2 Tansy Hoskins, "Reliving the Rana Plaza Factory Collapse: A History of Cities in 50 Buildings, Day 22" The Guardian (23 April 2015), online: Guardian News and Media Limited <http://www.theguardian.com/cities/2015/apr/ 23/rana-plaza-factory-collapse-history-cities-50-buildings>; Jason Motlagh \& Atish Saha, "The Ghosts of Rana Plaza: In Bangladesh, One Year After the Worst Accident in the History of the Garment Industry, Recovery Remains a Fragile Process, Justice Seems Elusive, and Reform has a Long Way to Go" (2014) 90 Va Q Rev 44 at 77 [Motlagh \& Saha]; See Appendix B, infra at page 157.

${ }^{3}$ Motlagh, ibid at 77; "Bangladesh Building Collapse Death Toll Passes 500" BBC News (3 May 2013), online: British Broadcasting Corporation $<$ http://www.bbc.com/news/world-asia-22394094> [BBC].

${ }^{4}$ Motlagh, ibid at 70 .

${ }^{5}$ Marc Bain \& Jenni Avins, “The Thing That Makes Bangladesh's Garment Industry Such a Huge Success Also Makes it Deadly" Quartz (24 April 2015), online: Quartz <http://qz.com/389741/the-thing-that-makes-bangladeshsgarment-industry-such-a-huge-success-also-makes-it-deadly/>; See Appendix A, infra at page 156.

6 "Signatories" Accord on Fire and Building Safety in Bangladesh (2015), online: Bangladesh Accord $<\mathrm{http}: / /$ bangladeshaccord.org/signatories/>. 
between manufacturers and suppliers to ensure a safe working environment where no employee fears deaths or injuries resulting from fires or building collapses, which could be prevented by adopting precautionary measures. ${ }^{7}$ However, because of the legally binding nature of the Accord, and provisions that could possibly lead to litigation, numerous American manufacturers have refused to sign the agreement. ${ }^{8}$ Therefore, the Alliance for Bangladesh Worker Safety (hereinafter "Alliance") 9 , which has been criticized as a "pale imitation" of the Accord, was signed by American manufacturers. ${ }^{10}$

In spite of their differences, both the Accord and Alliance require independent inspection of signatory suppliers. They further require that manufacturers and suppliers deposit funds to remedy hazards that are found upon examination. ${ }^{11}$ If a supplier factory is non-compliant, contractual relationships may be terminated, ${ }^{12}$ and this option has been used. ${ }^{13}$ More importantly, immediately after the collapse, the Rana Plaza Coordination Committee (hereinafter "RPCC")

\footnotetext{
7 “About the Accord" Accord on Fire and Building Safety in Bangladesh (2015), online: Bangladesh Accord <http:// bangladeshaccord.org/about/>.

${ }^{8}$ Alexandra Caleca, "The Effects of Globalization on Bangladesh's Ready-Made Garment Industry: The High Cost of Cheap Clothing" (2014) 40 Brook J Int'l L 279 at 309 [Caleca].

9 "Membership" Alliance for Bangladesh Worker Safety (2015), online: Bangladesh Worker Safety $<\mathrm{http}$ // www.bangladeshworkersafety.org/who-we-are/membership>.

${ }^{10}$ Stephen Greenhouse \& Stephanie Clifford, "U.S. Retailers Offer Plan for Safety at Factories" The New York Times (10 July 2013), online: The New York Times <http://www.nytimes.com/2013/07/11/business/global/us-retailersoffer-safety-plan-for-bangladeshi-factories.html $>$.

11 "Accord on Fire and Building Safety in Bangladesh" Accord on Fire and Building Safety in Bangladesh (13 May 2013), online: Bangladesh Accord <http://bangladeshaccord.org/wp-content/uploads/2013/10/the_accord.pdf $>$ at Articles $1 \& 24$ [Accord]; "Members Agreement" Alliance for Bangladesh Worker Safety (2015), online: Bangladesh Worker Safety <http://www.bangladeshworkersafety.org/files/Alliance-Member-Agreement-FINAL.pdf $>$ at Articles 1-2 [Alliance: Agreement].

${ }^{12}$ Accord, ibid at Art 21; Alliance: Agreement, ibid at Art 6.

13 "Terminated Suppliers" Accord on Fire and Building Safety in Bangladesh (2015), online: Bangladesh Accord $<$ http://bangladeshaccord.org/terminated-suppliers-2/>; "Suspended Factories" Alliance for Bangladesh Worker Safety (2015), online: Bangladesh Worker Safety <http://www.bangladeshworkersafety.org/factory/suspendedfactories>.
} 
was initiated as a combined effort between manufacturers, nongovernmental organizations, the Government of Bangladesh (hereinafter "GOB"), trade unions, and other industries in Bangladesh, for the sole purpose of compensating victims of the collapse. ${ }^{14}$ The manufacturers involved in the inception of the RPCC include El Corte Inglés, Primark, and LCL, ${ }^{15}$ who have announced, on 8 June 2015, that they have reached their target of $\$ 30$ million and can now fully compensate all victims. ${ }^{16}$

While donors ${ }^{17}$ to the RPCC are to be praised, what cannot be forgotten is that their activities were voluntary and the question of legal liability never arose, since the payment of compensation was not tied to any process of accountability. Therefore, since accountability has never been determined, the question that arises is who is legally responsible? Specifically, in this Thesis, I seek to determine whether LCL, a corporation headquartered and incorporated under the laws of Ontario, can be held legally accountable for the deaths and injuries resulting from the collapse of Rana Plaza, a locally owned facility in Bangladesh. ${ }^{18}$ To answer this question, I examine the law of negligence and import the theories of enterprise liability and vicarious liability. Using these theories, I will demonstrate how LCL introduced a risk into the community, which turned harmful and thus, it would not be unjust to hold LCL liable.

\footnotetext{
14 "Governance" Rana Plaza Coordination Committee (20 November 2013), online: Rana Plaza Arrangement $<$ http://www.ranaplaza-arrangement.org/mou/governance>.

15 Ibid.

16 "UPDATE: RPCC Announce that Sufficient Funds Now Available to Complete Payments Under the Rana Plaza Arrangement" Rana Plaza Coordination Committee (8 June 2015), online: Rana Plaza Arrangement $<$ http:// www.ranaplaza-arrangement.org/>; Stable URL <http://www.ranaplaza-arrangement.org/fund/donors/donors > .

${ }^{17}$ For a list of donors, see "Donors" Rana Plaza Coordination Committee (18 September 2015), online: Rana Plaza Arrangement $<$ http://www.ranaplaza-arrangement.org/fund/donors $>$.

18 "Securities Law \& Instruments: In the Matter of Loblaw Companies Limited and Provigo Inc" Ontario Securities Commission (17 December 2003), online: OSC <https://www.osc.gov.on.ca/en/

SecuritiesLaw_ord_20040102_2511_loblawcompanies.htm>.
} 


\section{A - THEORETICAL FRAMEWORK}

It is well established in the common law world that a corporation is a legal entity distinct from its shareholders and that a parent corporation is a legal entity distinct from its wholly owned subsidiary. ${ }^{19}$ It is this principle of separate legal personality that means the law does not hold persons, natural or fictitious, accountable for nonfeasance or misfeasance of another person. ${ }^{20}$ A statement of this principle was put forward by Oliver Wendell Holmes Jr. in an oftenquoted passage:

I assume that common-sense is opposed to making one man pay for another man's wrong, unless he actually has brought the wrong to pass according to the ordinary canons of legal responsibility, - unless, that is to say, he has induced the immediate wrong-doer to do acts of which the wrong [...] was the natural consequence under the circumstances known to the defendant. ${ }^{21}$

This concept is considered sacred in corporate law and to breach this would be sacrilege.

The principle of separate legal personality has led courts to not impose liability on a parent company for the misconduct of its subsidiary. ${ }^{22}$ A parent company is a corporation that has a controlling interest in another corporation, which is known as a subsidiary corporation. ${ }^{23}$

Courts are generally reluctant to "pierce the corporate veil," which is a judicially imposed exception to the principle of separate legal personality, permitting plaintiffs access to the assets

\footnotetext{
${ }^{19}$ Salomon v Salomon \& Co Ltd, [1897] AC 22, 66 LJ Ch 35, at 43 [Salomon]. Also see Ivan Feltham, Lifting the Corporate Veil (Toronto: R. De Boo, 1968) at 305 [Feltham].

${ }^{20}$ Phillip Blumberg, "Accountability of Multinational Corporations: The Barriers Presented by Concepts of the Corporate Juridicial Entity”(2000-2001) 24 Hastings Int'1 \& Comp L Rev 297 at 300 [Blumberg].

${ }^{21}$ Oliver Wendell Holmes Jr., “Agency” (1891-1892) 5 Harv L Rev 1 at 14.

22 Blumberg, supra note 20 at 303.

${ }^{23}$ Garner et al, eds, Black's Law Dictionary, 9 ${ }^{\text {th }}$ ed (St. Paul, Minn: West Publishing Co, 2009) at 393.
} 
of a shareholder. ${ }^{24}$ Nonetheless, courts have recognized three exceptions when separate legal personality can be disregarded and the corporate veil can be pierced: when the corporation lacks a separate identity, where the corporation acts as an agent of the principal (parent company), and where statute provides, and I will examine the three excepted criteria in greater detail in Chapter 3. ${ }^{25}$ However, courts have said that even a parent company's $100 \%$ ownership of its subsidiary is insufficient to hold the parent company liable for the subsidiary's misconduct. ${ }^{26}$ This further indicates just how strict courts are in piercing claims.

Additionally, in a globalized world, a parent corporation operates multinational enterprises (hereinafter "MNE") containing corporate structures of "incredible complexity."27 This web of corporate structures consists of numerous subsidiaries, established in more than one country that are collectively involved in a single business enterprise under the control of the parent corporation. ${ }^{28}$ For example, British Petroleum is comprised of more than 1,200 subsidiaries, which the law views as 1,200 independent entities, and, as I have mentioned above, one entity will generally not be found liable for the misconduct of another. ${ }^{29}$ As a result, it is not uncommon to see MNEs locate to developing countries and evade liability for conduct that is

\footnotetext{
${ }^{24}$ Robert Thompson, "Piercing the Corporate Veil: An Empirical Study" (1990-1991) 76 Cornell L Rev 1036 at 1036. A "shareholder" can be a natural person, such as a sentient being, or another corporation, at 1036; Blumberg, supra note 20 at 305-306.

${ }^{25}$ Blumberg, supra note 20 at 304-308; 642947 Ontario Ltd v Fleischer, [2001] OJ No 4771 [Fleischer]; Parkland Plumbing \& Heating Ltd v Minaki Lodge Resort, [2009] ONCA 256 [Parkland].

${ }^{26}$ Blumberg, ibid at 305; José Antunes, “The Liability of Polycorporate Enterprises” (1998-1999) 13 Conn J Int'l L 197 at 203.

${ }^{27}$ Blumberg, ibid at 303.

28 “OECD Guidelines for Multinational Enterprises: 2011 Edition” Organization for Economic Cooperation and Development (2011), online: OECD <http://www.oecd.org/corporate/mne/48004323.pdf> at 17.

${ }^{29}$ Blumberg, supra note 20 at 303; I must clarify that 'enterprise' refers to the unified economic group, while 'entity' refers to the singular, legal form of a corporation.
} 
prohibited in developed countries, or their home state. ${ }^{30}$ It is this action that has imported a great deal of attention on the issue of corporate liability.

Two widely known examples of when parent companies were not held liable for the misconduct of their subsidiaries occurring overseas are Union Carbide Corporation (hereinafter "UCC") ${ }^{31}$ and Unocal Corporation (hereinafter "Unocal"). ${ }^{32}$ The subsidiary of UCC's misconduct resulted in three thousand deaths in India, ${ }^{33}$ while Unocal's subsidiary engaged in acts of rape and torture in Myanmar. ${ }^{34}$ In both cases, plaintiffs alleged liability on the parent corporation for the misconduct of its subsidiary, but the parent company was shielded from liability on grounds of separate legal personality. ${ }^{35}$ The United States, Canada, and the rest of the common law world is visibly hesitant in imposing liability on a parent corporation for the tortious conduct of its subsidiaries. ${ }^{36}$

Due to globalization, which I will explain in more detail in the subsequent Chapter, MNEs gained overnight affluence, becoming a "power unto themselves" whose revenues are

${ }^{30}$ Michael Addo, ed, Human Rights Standards and The Responsibility of Transnational Corporations (The Netherlands: Kluwer Law International, 1999) at 132 [Addo]; The term 'developing countries' is used to describe those nations that are situated in the Southern portion of the globe, such as India and Guatemala to differentiate from those countries that have achieved material prosperity; See generally Jane Parpart and Henry Veltmeyer, "The Development Project in Theory and Practice: A Review of its Shifting Dynamics" (2004) 25 Can J Dev Stud 39. Conversely, Bangladesh is one of 48 Least Developed Countries, at "List of Least Developed Countries (as of 16 February 2016)" United Nations Department of Economic And Social Affairs Development Policy and Analysis Division Committee for Development Policy (16 February 2016), online: United Nations <http://www.un.org/en/ development/desa/policy/cdp/ldc/ldc_list.pdf $>$.

${ }^{31}$ Richard Clayton Trotter, Susan Day \& Amy Love, "Bhopal, India and Union Carbide: The Second Tragedy" (1989) 8 J Bus Ethics 439 [Trotter].

32 Meredith Dearborn, “Enterprise Liability: Reviewing and Revitalizing Liability for Corporate Groups” (2009) 97 Cal L Rev 195 [Dearborn].

${ }^{33}$ Injuries of permanent disablement range in the ten thousands, at Marc Galanter, "Bhopals, Past and Present: The Changing Legal Response to Mass Disaster” (1990) 10 Windsor YB Access Just 151 at 152.

${ }^{34}$ Dearborn, supra note 32 at 195.

35 Trotter, supra note 31 at 439-440; Dearborn, ibid at 197.

${ }^{36}$ Garcia v Tahoe Resources Inc., [2015] BCSC 2045; Fleischer, supra note 25; Parkland, supra note 25. 
greater than numerous nations. ${ }^{37}$ Despite the amassing power, there is no institution governing the conduct of MNEs. Furthermore, though MNEs are operating in multiple jurisdictions, international law does not hold them accountable, which I will explain in Chapter $3 .{ }^{38}$ Therefore, MNEs are increasingly organizing in ways where the parent company avoids liability by delegating activities that can lead to litigation to its subsidiaries. ${ }^{39}$ This evasion of liability through the use of intricate webs of corporate structures has led John Ruggie to conclude that "the escalating exposure of people and communities to corporate-related abuses" makes reforming MNE liability an "urgent policy priority." 40 This begs the question of how a parent corporation can be held liable for the misconduct of its subsidiary occurring overseas. Moreover, the crux of the issue of Rana Plaza is that the facility was locally owned, thereby the corporation relinquished control over the activities of the building. ${ }^{41}$ As in, Rana Plaza was not a subsidiary of LCL, because if it were, a type of liability probably could have been traced to the latter. Local ownership of Rana Plaza only renders the ascription of liability on LCL even more improbable. Additionally, there arises an ancillary difficulty as the building was subcontracted by LCL. ${ }^{42}$ Subcontracting is when manufacturers contract the elements of cutting and sewing to a

\footnotetext{
${ }^{37}$ Peter Muchlinski, Multinational Enterprises and the Law, 2d ed (New York: Oxford University Press Inc, 2007) at 3 [Muchlinski]; Susan Marks \& Andrew Clapham, International Human Rights Lexicon (Toronto: Oxford University Press, 2005) at 182 \& 190 [Marks \& Clapham].

38 Steven Ratner \& Anne-Marie Slaughter, “Appraising the Methods of International Law: A Prospectus for Readers” (1999) 93 Am J Int'1 L 291 at 292.

${ }^{39}$ Henry Hansmann \& Reinier Kraakman, “Toward Unlimited Shareholder Liability for Corporate Torts” (1991) 100 Yale LJ 1879 at 1881.

40 John Ruggie, Promotion and Protection of all Human Rights, Civil, Political, Economic, Social and Cultural Rights, Including the Right to Development, UNHRCOR, 8th Sess, UN Doc A/HRC/8/5, (2008) 1 at 9.

${ }^{41}$ Alison Gormley, “The Underground Exposed: The United States Corporations' Use of Sweatshops Abroad, and the Abuse of Women" (2001-2002) 25 Suffolk Transnat'l L Rev 109 at 130 [Gormley].

42 Hollie Shaw, "Class Action Suit Seeks \$2 Billion from Loblaw, Joe Fresh Over 2013 Bangladesh Garment Factory Collapse” Financial Post (30 April 2015), online: Financial Post $<$ http://business.financialpost.com/news/retailmarketing/class-action-suit-seeks-2-billion-from-loblaw-joe-fresh-over-2013-bangladesh-garment-factory-collapse $>$.
} 
party, and that party then contracts the work to a third party contractor, thereby shielding the manufacturer from being held as the laborer's employer; hence, liability. ${ }^{43}$ Therefore, the ultimate question is not whether LCL can be held liable for the misconduct of its subsidiary; rather, it is whether LCL can be held liable for deaths and injuries arising in a locally owned facility in a different country based on the grounds that together, Rana Plaza and LCL were involved in one economic enterprise.

\section{i. The Theory of Enterprise Liability}

It is at this point that I import the theory of enterprise liability to demonstrate how LCL can be held liable. While Oliver Wendell Holmes Jr. first put forward the theory of enterprise liability in 1897, it was in 1947 that Adolf Berle suggested disregarding legal personalities in favor of a more pragmatic view of the corporate enterprise. ${ }^{44}$ As in, Berle viewed MNEs as a unified economic whole operating for a common purpose. This way, the concept of separate legal personality is "pure legal formalism" that shields the parent company from being held liable for its subsidiary's misconduct. ${ }^{45}$ To prevent this absurdity, Berle proposed enterprise liability so that a parent corporation can be held accountable for the tortious conduct of its subsidiary. ${ }^{46}$ That is, when the parent corporation is profiting from the subsidiary's operations, it must pay reparations to the victims injured from the subsidiary's misconduct.

\footnotetext{
${ }^{43}$ Laura Ho, Catherine Powell \& Leti Volpp, “(Dis)assembling Rights of Women Workers Along the Global Assembly Line: Human Rights and the Garment Industry” (1996) 31 Harv CR-CLL Rev 383 at 386 [Ho et al]; Also see Lora Jo Foo, "The Vulnerable and Exploitable Immigrant Workforce and the Need for Strengthening Worker Protective Legislation" (1994) 103 Yale LJ 2179 at 2185; Sarah Cleveland, "Global Labor Rights and the Alien Tort Claims Act” (1997-1998) 76 Tex L Rev 1533 at 1577-1578 [Cleveland].

44 Oliver Wendell Holmes Jr., "The Path of the Law" (1897) 10 Harv L Rev 457 at 466-467. This was also the year the House of Lords rendered their decision in Salomon v Salomon \& Co Ltd, at Salomon, supra note 19; Adolf Berle Jr., "The Theory of Enterprise Entity" (1947) 47 Colum L Rev 343 at 343 [Berle].

${ }^{45}$ David Leebron, “Limited Liability, Tort Victims, and Creditors” (1991) 91 Colum L Rev 1565 at 1575.

${ }^{46}$ Berle, supra note 44 at 344; Maurice Dix, "The Economic Entity” (1953) 22 Fordham L Rev 254 at 255.
} 
While Berle proposed the use of enterprise liability to hold a parent corporation liable for the misconduct of its subsidiary, he never mentioned whether the theory could be applied to a corporation when the events giving rise to litigation occurs in a facility that is not owned by that corporation. This is when the Supreme Court of Canada's (hereinafter "SCC") decision of Bazley v Curry (hereinafter "Bazley"), in 1999, is crucial as enterprise liability was consolidated with vicarious liability in an employment context. ${ }^{47}$ Vicarious liability is imposing liability on a person for a tortious act, or omission, that he did not commit. ${ }^{48}$ The only reason this form of liability is imposed is because of a relationship between the wrongdoer and the defendant. In Bazley, the SCC found that since a fundamental principle of vicarious liability is a "just and practical remedy" for the injury and because the employment enterprise and the resulting harm were "closely associated," the Children's Foundation (employment enterprise) can be held liable. ${ }^{49}$ As in, since the employment enterprise introduced a risk ripening into harm, it is just that he is held liable and bears the associated cost.

\section{ii. Summary of Arguments}

I import Bazley for two reasons; first, it is the use of enterprise liability and vicarious liability in Canada decided by the highest court in the country. Second, since Rana Plaza is not a subsidiary of LCL, and was subcontracted by LCL, Bazley demonstrates how the introducer of a risk can nonetheless be held liable in an employment context, as they were involved in the same economic enterprise. Overall, using the framework outlined above, my arguments are grounded

\footnotetext{
${ }^{47}$ Bazley v Curry, [1999] 2 SCR 534.

${ }^{48}$ Patrick Atiyah, Vicarious Liability in the Law of Torts (London: Butterworth \& Co Ltd, 1967) at 3 [Atiyah]; In simpler terms, if party A were hurt as a result of party B's misconduct, or omission, party C is held liable because of a relationship between party $\mathrm{C}$ and party $\mathrm{B}$ (usually an employment relationship).

${ }^{49}$ Bazley, supra note 47 at paras $29,31 \& 37-38$.
} 
on research showing that a parent company is generally not held liable for the misconduct of its subsidiary. Next, due to globalization, MNEs have proliferated and the number of MNEs are rising. While they are operating in multiple jurisdictions, international law does not hold MNEs accountable because it does not view them as subjects. In this gap of accountability, I turn to tort law to see how courts would determine liability. Relying on Bazley, I import the theories of enterprise and vicarious liability to demonstrate how LCL can be held liable.

However, in order to hold LCL vicariously liable, I show negligence on the part of Bazlus Adnan, the owner of New Wave, which was the factory inside Rana Plaza fabricating garments for LCL. ${ }^{50}$ That is, I reveal how Adnan was the employer of the victims and LCL was the employer of Adnan on grounds of enterprise liability. Though Rana Plaza was a subcontractor, I adduce evidence that LCL knew of Rana Plaza's labor, as it hired Bureau Veritas to conduct inspections of the facility. According to Patrick Atiyah, if an employing enterprise knows of the subcontract, he can justly be found liable. ${ }^{51}$ Therefore, since LCL was profiting from the activities of New Wave, and since LCL knew of the subcontract, it can be held vicariously liable on the grounds that Rana Plaza and LCL were involved in one economic enterprise.

\section{B - NOTES ON TERMINOLOGY}

\section{i. Manufacturer \& Supplier}

A manufacturer is the brand-name label, such as, Loblaw Companies Limited, Walmart, United Colors of Benetton, and Mango, who design and own the garments. ${ }^{52} \mathrm{~A}$ supplier is one

\footnotetext{
50 Tarannum Kamlani, "Made in Bangladesh" CBC The Fifth Estate (11 October 2013), online: CBC/Radio-Canada $<$ http://www.cbc.ca/fifth/episodes/2013-2014/made-in-bangladesh>.

${ }^{51}$ Atiyah, supra note 48 at 346.

${ }^{52}$ Ho et al, supra note 43 at 385-386.
} 
who furnishes products to the manufacturer because the latter has contracted the act of production to the supplier. Therefore, to avoid confusion, I use the phrase 'fabricate garments' when describing the work being done at Rana Plaza, and not 'manufacture garments.'

\section{ii. Rana Plaza \& New Wave}

Rana Plaza was the facility that was owned by Sohel Rana, and it housed six garment factories. Among them, New Wave was the factory that was fabricating garments for LCL. While I refer to the 'collapse of Rana Plaza' as a whole, my concern is restricted to the victims of New Wave, even though I consistently refer to 'the collapse of Rana Plaza' at its entirety.

\section{C - IMPORTANCE OF RESEARCH \& GAP IN KNOWLEDGE}

Considering the novelty of this issue, compounded with the magnitude of the collapse of Rana Plaza, whose tremors are still felt three years later, it becomes important. The corollary of the collapse of Rana Plaza and seeking to hold LCL accountable is a discussion of neoliberalism, globalization, and global governance. Neoliberalism and globalization will provide context delineating why MNEs outsource elements of production overseas, facilitating international trade. However, I will currently focus my attention on global governance to demonstrate the importance of my research.

Due to globalization, there are more than 80,000 MNEs, 800,000 subsidiaries, and millions of suppliers around the globe, for which stability ought to be preserved with respect to transboundary problems so that this growth is not impeded. ${ }^{53}$ To preserve transboundary stability,

\footnotetext{
${ }^{53}$ John Ruggie, Report of the Special Representative of the Secretary General on the Issue of Human Rights and Transnational Corporations and other Business Enterprises, UNHRCOR, 17th Sess, UN Doc A/HRC/17/31, (2011) 1 at 5 .
} 
and since globalization has created a situation of interdependence, global governance emerged. ${ }^{54}$ Global governance is a set of laws, policies, and institutions that govern relations internationally between markets, citizens, and States to bring stability and predictability to global problems. ${ }^{55}$ As in, a set of informal and formal ideas, procedures, and institutions constitute global governance that help States, intergovernmental organizations, nongovernmental organizations, MNEs, and individuals address international issues that no individual State can solve. ${ }^{56}$

John Ruggie cites the United Nations (hereinafter "UN") and the World Trade Organization (hereinafter "WTO"), along with treaties and customary international law, to be instruments of global governance.$^{57}$ Others also include the International Monetary Fund (hereinafter "IMF") and the International Bank for Reconstruction and Development (more commonly known as the "World Bank") in the same category. ${ }^{58}$ However, international law, UN, the WTO, IMF, and the World Bank are concerned with relationships between States and holding States accountable — not MNEs. This has led numerous scholars to doubt whether international law can address the challenges modern MNEs pose. ${ }^{59}$ Therefore, if institutions that govern relationships between States do not try to establish MNE liability, what is the avenue through which victims harmed by MNE misconduct seek redress?

\footnotetext{
54 Thomas Weiss, Governing the World? Addressing "Problems without Passports" (Colorado: Paradigm Publishers, 2014) at 11 [Weiss]. Again, this is of paramount importance owing to globalization.

55 Thomas Weiss \& Ramesh Thakur, Global Governance and the UN: An Unfinished Journey (Indiana: Indiana University Press, 2010) at 6 [Weiss \& Thakur].

56 Weiss, supra note 54 at 4.

57 Weiss \& Thakur, supra note 55 at Xv (Foreword by John Ruggie).

58 Joseph Stiglitz, Globalization and its Discontents (New York: W.W. Norton \& Co, 2002) at 10 \& 21.

${ }^{59}$ Fleur Johns, "The Invisibility of the Transnational Corporation: An Analysis of International Law and Legal Theory" (1993-1994) 19 Melbourne UL Rev 893; Ilias Bantekas, "Corporate Social Responsibility in International Law” (2004) 22 BU Int'l LJ 309; David Kinley \& Junko Tadaki, "From Talk to Walk: The Emergence of Human Rights Responsibilities for Corporations at International Law” (2003-2004) 44 Va J Int'l L 931.
} 
Since there is no institution governing MNE misconduct or provide reparation to those injured from the activities of MNEs, it is important to find an avenue through which MNEs can be held liable. As I will demonstrate in Chapter 2, globalization will not diminish and such problems will not vanish. While enterprise liability is one approach through which a parent corporation could be held liable for the misconduct of its subsidiaries, it does not speak to whether a corporation will be held accountable for misconduct taking place in a facility that is not owned by the corporation. This also begets a gap in knowledge.

A knowledge gap is marked by little or no consensus "about the nature [and] magnitude of a problem" because of insufficient empirical research, and this gap creates disagreement about the best solution to the problem. ${ }^{60}$ It is to this gap in knowledge that I wish to contribute, using enterprise liability and vicarious liability to delineate how LCL and Rana Plaza were collectively involved in the same economic enterprise and since LCL introduced a risk into the community, it would not be unjust to hold LCL liable.

My research can also contribute to a normative gap, defined as that which is generally accepted as the most common and usual pattern of behavior. ${ }^{61}$ Currently, the norm is that a parent corporation will not be found liable for the misconduct of its subsidiary, but this could change. As Martha Finnemore and Kathryn Sikkink have said, a new concept first emerges - Holmes and Berle and enterprise liability. Then, when enough actors agree on it, it is accepted. ${ }^{62} \mathrm{I}$ do not think that the consolidation of enterprise liability and vicarious liability will find general acceptance to hold a corporation liable for acts occurring overseas in a facility unowned by the

\footnotetext{
${ }^{60}$ Weiss \& Thakur, supra note 55 at 8.

${ }^{61}$ Ibid at 10.

${ }^{62}$ Ibid.
} 
corporation. However, I am convinced that if the relationship between a supplier and manufacturer is similar to that of Rana Plaza and LCL, this paper could serve as an example of how future arguments could be constructed on the premise of enterprise liability.

My contribution to these lacunae in knowledge could deconstruct the legal intricacies of Rana Plaza and future similar cases. Analogous to the reverberating impact of Edwards $v$ Canada (Attorney General), Rana Plaza carries the potential to serve as a landmark case that could bring about the liability of corporations for deaths resulting from its enterprise even when it occurs overseas. As an international student from Bangladesh (with, I add without arrogance, a privileged background), I feel morally obligated to explore this topic. In clarification, I say that this obligation is not saddled on me. Additionally, it is not one that will prejudice my objective understanding of the law. Rather, it is a deeply held, dispassionate belief that I could help clarify the legal labyrinth under which this case is buried. As I have been granted the intellectual freedom to pursue this topic, I feel that a disservice would be done to legislatures, academics, lawyers, and the victims of Rana Plaza if I were to not.

\section{D - METHODOLOGY \& CHAPTER OUTLINES}

This project uses the theoretical framework outlined above in two ways. First, I demonstrate how difficult it is to hold a parent company liable for the misconduct of its subsidiary because of the concept of limited liability. However, since globalization has permitted corporations to operate overseas, a more practical solution to this problem is required. Second, as a solution to the problem, I import the theories of enterprise and vicarious liability while drawing on the case of Bazley. Using the SCC's guidelines in Bazley, I apply its framework to the case of Rana Plaza and demonstrate how it fits within the economic enterprise of LCL. 
The primary reason as to why I rely on Bazley is because it would help delineate how LCL can be held liable for the collapse of Rana Plaza. Since Rana Plaza was not a subsidiary of LCL, I am barred from using any of the excepted criteria of when courts hold parent companies liable for the misconduct of its subsidiary. Additionally, the case study of Rana Plaza is not about whether it engaged in misconduct for which to hold LCL liable. Rather, since I am concerned with the collapse of Rana Plaza that resulted in deaths and injuries, I must show that Rana Plaza and LCL were involved in one economic enterprise. Thus, I will be able to demonstrate this task by importing Bazley and using its framework.

Chapter 1 has been dedicated to provide background information on my research question and intimate its overall structure. I have briefly explained the concept of limited liability and how it prevails over enterprise liability. I then went on to suggest that globalization will not diminish. Therefore, it is important to fill the lacuna resulting from scarce knowledge in finding an avenue through which victims of MNE misconduct could hold the parent corporation liable.

In Chapter 2, I will begin by expanding on the historical basis of international trade. Then, I will elaborate upon neoliberalism and globalization, which will provide context to why MNEs outsource production and show why MNEs will continue to do so. That is, because of globalization, the cost of transportation has been nearly eliminated, and as such, MNEs have built interconnected networks of supply chains, which is where Rana Plaza is situated. To this end, I will draw on literature from Milton Friedman, Friedrich Hayek, Joseph Stiglitz, Peter Muchlinski, Michael Addo, Susan Marks and Andrew Clapham, Frank Lechner and John Boli, and Dani Rodrik. This will lead me to speak of globalization's effect on Bangladesh, transforming the nation into the second largest exporter of RMG, citing authoritative sources of 
the ILO, IMF, WTO, the World Bank, and Alexandra Caleca. I will conclude the Chapter by discussing the accruing power of MNEs and whether the said phenomenon will continue.

In Chapter 3, I will begin by discussing international law's failure to hold MNEs accountable for tortious conduct because of its 'State-centric' approach, drawing on the works of Steven Ratner, Anne-Marie Slaughter, Nico Krisch, and Michael Byers. I then discuss soft law instruments in regulating MNEs, but show that they are weak instruments because no organization is vested with the authority to ensure MNEs comply with soft law. MNEs also adopt voluntary codes to repair their tarnished images and seem socially responsible, because a corporation's negative image causes it to lose money. However, this is still problematic as no one monitors whether the MNE complies with its own codes. It is then that I discuss that victims harmed by MNE misconduct have recourse to courts, but the issue of separate legal personality poses a challenge, where I import the works of Frank Easterbrook and Daniel Fischel, Phillip Blumberg, Richard Posner, and Henry Hansmann and Reinier Kraakman. It is then that I arrive at enterprise liability, offering an economical view of holding corporations liable.

In Chapter 4, I will begin by discussing Bazley. This will lead me to offer my analysis of whether LCL could be held liable for the deaths and injuries resulting from the collapse of Rana Plaza. I will, relying on the works of John Fleming, Bruce Feldthusen and Allen Linden, and Page Keeton, demonstrate how Adnan was negligent in allowing the victims to enter Rana Plaza and begin work despite being aware of a crack on the structure. Afterwards, I will establish that based on the degrees of communication between LCL and Rana Plaza, the former assumed an 'employer' role, and thus, because the two were involved in one economic enterprise, LCL could be held vicariously liable for Adnan's negligence. 
Chapter 5 will link the work together. Here, I will provide a compendious summary of my findings and remind readers that my arguments can only be used in those circumstances where the supplier and the corporation can be shown to be involved in one economic enterprise. Lastly, I will propose the establishment of the International Board for Corporate Conduct. I feel compelled to clarify that my intention is not to displace the doctrine of limited liability and detract from Salomon v Salomon \& Co Ltd, as some have argued for abolishing piercing the corporate veil. ${ }^{63}$ Rather, my wish is to contribute to the literature of enterprise liability and demonstrate that it is better tailored, for the purposes of accountability, to the nature of the business of modern MNEs. This is not to suggest that every corporation ought to be held liable for such activities, but only for those activities that can be shown as being part of the economic enterprise of the corporation.

\section{E - DELIMITATIONS}

Though Bangladesh is the second largest exporter of RMG, factory fires and building collapses have killed more than 1,800 workers since 2005 - Rana Plaza excepted.64 However,

\footnotetext{
${ }^{63}$ Stephen Bainbridge, “Abolishing Veil Piercing” (2000-2001) 26 J Corp L 479.

${ }^{64}$ Caleca, supra note 8 at 290; See generally "Savar Tragedy: Factory Owner Surrenders, Sent to Jail" The Daily Star (9 May 2005), online: The Daily Star <http://archive.thedailystar.net/2005/05/09/d5050901033.htm>; Tasneem Khalil, "18 Killed in Building Collapse" CNN (25 February 2006), online: CNN <http://www.cnn.com/2006/ WORLD/asiapcf/02/25/bangladesh.building.collapse/>; "12 Dead in Bangladesh Garment Factory Fire" Clean Clothes (1 August 2000), online: Clean Clothes <https://archive.cleanclothes.org/newslist/129.html >; Farid Hossain, "Dozens Die in Fire at Bangladesh Factory" The Guardian (27 November 2000), online: Guardian News and Media Limited <http://www.theguardian.com/world/2000/nov/27/bangladesh>; "Garment Workers Die in Bangladeshi Fire Alarm" Clean Clothes (1 August 2001), online: Clean Clothes <http://www.cleanclothes.org/news/2001/08/01/ garment-workers-die-in-bangladeshi-fire-alarm>; "Three Tragedies Hit Bangladesh Factories in One Week, Leaving Scores Dead, Wounded" Clean Clothes (27 February 2006), online: Clean Clothes $<\mathrm{http}$ ://www.cleanclothes.org/ news/2006/02/27/three-tragedies-hit-bangladesh-factories-in-one-week-leaving-scores-dead-wounded >; "Six Roasted Alive in Fire at Jamuna Spinning Mill in Gazipur, 2nd Ld" BDNews 24 (2 August 2006), online: BDNews24 <http://bdnews24.com/bangladesh/2006/02/08/six-roasted-alive-in-fire-at-jamuna-spinning-mill-ingazipur-2nd-ld>; "Toll Rise to 54 in Bangladesh Textile Fire" The New York Times (24 February 2006), online: The New York Times $<$ http://www.nytimes.com/2006/02/24/world/asia/24iht-web.0224bangla.html?_r=1\&>; "Timeline: Deadly Factory Accidents in Bangladesh" CBC News (9 October 2013), online: CBC News <http://www.cbc.ca/ news2/interactives/timeline-bangladesh/>.
} 
my research is restricted to the case of Rana Plaza, as it was the deadliest structural failure in the history of the world's garment industry, claiming 1,134 lives. ${ }^{65}$ The implication is not because Rana Plaza has become cause célèbre that I choose to examine the case. Since this case is recent and has claimed the most lives in a single tragedy, it is my focal point. I clarify that this is not indicia of disregard to the others injured or deceased from separate tragedies; rather, it is that I cannot incorporate other building collapses, as the incorporation would be beyond the breadth of this Thesis. I acknowledge that the inclusion of other disasters would be more illuminative of the nature of the RMG industry in Bangladesh, but the legal intricacies would render it impossible to delve into the minutiae of each case.

\section{i. Why Only Loblaw and Not Hold Other Corporations Liable?}

Another caveat to my project is that I focus solely on Loblaw Companies Limited. As in, I have not sought to determine whether El Corte Inglés, Mango, or Primark could be accountable. Firstly, I have not asked whether European companies could be held liable because the European legal system is not conducive to class action lawsuits. ${ }^{66}$ Secondly, Europe disallows contingency fees, where a fee is paid to counsel only if the party wins, which is allowed in the United States and Canada. Therefore, in Europe, even if the plaintiff loses, he would be required to pay counsel, which generally becomes unconscionably expensive.

\section{ii. $\quad$ The United States has Cordoned its Courts}

In reference to the United States, a recent decision by the Supreme Court of the United States, Kiobel v Royal Dutch Petroleum Co (hereinafter "Kiobel"), presages that it has cordoned

\footnotetext{
${ }^{65} \mathrm{BBC}$, supra note 3.

${ }^{66}$ John Coffee Jr, “Litigation Governance: Taking Accountability Seriously” (2010) 110 Colum L Rev 288 at 292.
} 
its courts from accepting claims made under the Alien Tort Claims Act (hereinafter "ATCA"). ${ }^{67}$

Generally, overseas workers harmed by American corporations would bring litigation to courts of the United States filing a claim under the $A T C A$, which happened to the benefit of 30,000 plaintiffs when, inter alia, Gap and Walmart settled a \$20 million lawsuit in 2003. While I am not unaware that the victims of Rana Plaza have filed a lawsuit against Walmart and the GOB at a federal court in Washington D.C., the case has also been dismissed. ${ }^{68}$

\section{iii. What if Litigation Against Loblaw Fails?}

Fourth, Rochon Genova, a Toronto law firm, has commenced a \$2 billion lawsuit against LCL on behalf of the victims of Rana Plaza. ${ }^{69}$ If their claim fails, it is a disservice to my paper, as it would demonstrate the contrary of what I essentially argue. Nonetheless, even if the Ontario Superior Court of Justice decides against the plaintiffs, I am of the opinion that my paper could still serve a useful purpose, again, by heralding how future arguments could be constructed for similar situations in academia.

\section{iv. Recent Statutory Developments}

In California, the California Transparency in Supply Chains Act (hereinafter "CTSCA") has been in effect from 1 January $2012 .{ }^{70}$ Pursuant to Section 3(a)(1), the CTSCA seeks to eradicate the use of slavery and human trafficking in the supply chains of corporations that are

\footnotetext{
${ }^{67}$ Kiobel v Royal Dutch Petroleum Co, 133 S Ct 98 (2013).

${ }^{68}$ Steven Greenhouse, "U.S. Retailers See Big Risk in Safety Plan for Factories in Bangladesh" The New York Times (22 May 2013), online: The New York Times <http://www.nytimes.com/2013/05/23/business/legal-experts-debateus-retailers-risks-of-signing-bangladesh-accord.html?_r=0>; Leon Kaye, "U.S. Court Dismisses Rana Plaza Lawsuit" Triple Pundit (9 May 2016), online: Triple Pundit <http://www.triplepundit.com/2016/05/u-s-courtdismisses-rana-plaza-lawsuit/\#>.

69 "Rana Plaza" Rochon Genova (2016), online: Rochon Genova LLP $<$ http://www.rochongenova.com/CurrentCases/Rana-Plaza.shtml $>$. The Statement of Claim can be found at $<\mathrm{http}: / / \mathrm{www}$.rochongenova.com/Fresh-asAmended-Statement-of-Claim-filed-November-5-2015.pdf $>$.

${ }^{70} \mathrm{Cal}$ Civ Code, $\S 1714.43$; To view the $C T S C A$, see <http://www.state.gov/documents/organization/164934.pdf>
} 
headquartered in California. In the United Kingdom, the Modern Slavery Act 2015 (hereinafter "MSA") seeks to accomplish the same ends. ${ }^{71}$ In Canada, there is no analogous statute. However, I do not discuss the CTSCA and the MSA until Chapter 5 because I am not primarily concerned with whether slavery and human trafficking was used at Rana Plaza. ${ }^{72}$

\section{v. Omission in Discussing the Government of Bangladesh}

Lastly, I have not asked whether the Government of Bangladesh can be held liable for its lack of oversight of the shoddy construction of Rana Plaza. While The Building Construction Act, 1952 permits the GOB, pursuant to Articles 3B, 5, 7, and 10A, to stop construction that is being done so in a haphazardly manner, the GOB has displayed a repeated inability of doing so. ${ }^{73}$ This would invite complex questions regarding the police, bureaucrats, and the judiciary of Bangladesh to unearth why the GOB has failed to oversee construction, which would transform this Thesis into an inordinately long one. ${ }^{74}$ Thus, since Rana Plaza is situated at an interesting crossroad in business (globalization) and law, I am of the opinion that a disquisition about whether LCL could be held liable for its collapse would be more informative instead of asking the common question of why the GOB has failed to prevent the tragedy.

\footnotetext{
${ }^{71}$ Modern Slavery Act 2015 (UK), c 30.

72 The reason I have elected to forgo a thorough discussion of the aforementioned statutes is because they are concerned with the eradication of slavery and human trafficking in the supply chains of corporations. While there exists no similar legislation in Canada, in Chapter 5, I will recommend that Canada should promulgate an analogous statute. Additionally, its scope should also impose a duty on the Canadian corporation to ensure a safe and healthy workplace for employees fabricating products for that corporation. Furthermore, while I have briefly mentioned the operations of UCC and Unocal when speaking of entity law above, I do not discuss these cases further. Though, their discussion would have demonstrated courts' constant refusal to hold parent companies liable for the misconduct of their subsidiary's operations, an exploration of the cases would be beyond the breadth of my Thesis.

${ }^{73}$ The Building Construction Act, 1952 (Bangladesh), Act No 2 of 1953, at Arts 3B, 5, 7, 10A; Retrieved from $<$ http://bdlaws.minlaw.gov.bd/pdf_part.php?id=254>; See note 64, supra.

${ }^{74}$ Shariful Islam, Politics - Corruption Nexus in Bangladesh: An Empirical Study of the Impacts on Judicial Governance (Kowloon, Hong Kong: Asian Legal Resource Centre, 2010); Essentially, if I were to launch a disquisition on the GOB's consistent failure, I would need to discuss the corruption of the country's police and judiciary. I have elected to forgo this discussion.
} 


\section{II - GEOGRAPHICAL BARRIERS ARE ONLY SEEN IN CARTOGRAPHY}

In this Thesis, I seek to determine whether LCL could be held liable for the deaths and injuries resulting from the collapse of Rana Plaza. This Chapter will explore neoliberalism and globalization, explaining the rise of MNEs and its transboundary operations, while demonstrating why LCL was having garments fabricated in Bangladesh. I will then discuss the rise of Bangladesh in global garment production, and show how its garment industry is rapidly growing. This Chapter provides critical background information, describing how international economic integration has created interdependence, with MNEs amassing unparalleled power. Compounded with the fact that globalization will not diminish, for the purposes of global governance, it is important to find an avenue through which victims harmed by MNE misconduct can seek redress.

\section{A - FOUNDATIONAL TENET FOR INTERNATIONAL TRADE}

It is to the intellect of David Hume, Adam Smith, and David Ricardo for which there exists any current form of international trade. ${ }^{1}$ Countries entering into trade agreements are particularly guided by Ricardo's theory of comparative advantage, which suggests that each country should focus on producing goods with the lowest associated opportunity costs. ${ }^{2}$ In simpler terms, while some countries may not have an absolute advantage in any given area of production, they can produce certain goods more efficiently than others. ${ }^{3}$ Free trade is a central component of the theory of comparative advantage, suggesting that a country can increase its

\footnotetext{
${ }^{1}$ Michael Trebilcock, Robert Howse \& Antonia Eliason, The Regulation of International Trade, 4th ed (New York: Routledge, 2013) at 3-4 [Trebilcock et al].

2 Ibid. David Ricardo, The Principles of Political Economy and Taxation (London: J.M. Dent \& Sons Ltd, 1911) at 79-80.

${ }^{3}$ John Black, Nigar Hashimzade \& Gareth Myles, A Dictionary of Economics, 4th ed (Oxford: Oxford University Press, 2012) sub verbis "comparative advantage", "absolute advantage" \& "opportunity cost" [Black et al].
} 
wealth when it produces goods that it can manufacture most efficiently, and trades those goods with other countries to obtain what is not available domestically. ${ }^{4}$ Therefore, free trade is beneficial to both domestic producers and consumers. Producers benefit because they can specialize for maximum output, while consumers are offered a wider selection of goods that they can buy at a lesser price. ${ }^{5}$ For the reasons cited, it is commonly held that free trade promotes efficient division of labor and the allocation of resources, increasing economic prosperity within participating economies.

\section{i. Collaborative Reductions in Barriers to Trade}

In 1916, John Hobson suggested the "utilization of the economic resources of the world for the benefit of the world," demanding opening doors for trade, capital, and labor. ${ }^{6}$ In the $20^{\text {th }}$ century, the United States, directed by notions of classical liberal economics, became a proponent of free trade. ${ }^{7}$ Nearing the conclusion of the Second World War, the United States invited its wartime allies to enter into negotiations to rebuild the world economy through the reciprocal reduction of tariffs in goods, culminating in the Bretton Woods Conference in July 1944. ${ }^{8}$ The Second World War devastated the economies of Europe and Japan, with estimation that $40 \%$ of Great Britain's overseas assets were lost to expropriation, nationalization, or sale between 1939 to 1956. Additionally, since the United States emerged as the most powerful economy post 1945, its liberal economic policies were accepted, without much hesitation, by

\footnotetext{
${ }^{4}$ Trebilcock et al, supra note 1.

5 Ibid.

${ }^{6}$ John Hobson, Towards International Government (New York: MacMillan Company, 1916) at 142.

${ }^{7}$ Trebilcock et al, supra note 1 at 23 .

${ }^{8}$ Peter Van den Bossche, The Law and Policy of the World Trade Organization: Text, Cases and Materials (New York: Cambridge University Press, 2005) at 78-79 [Bossche].
} 
Europe. ${ }^{9}$ Nonetheless, even the United States was recovering from the Great Depression of the 1930s. ${ }^{10}$ In this volatile environment, when the world was emerging from political and economic chaos, John Maynard Keynes, a British economist key to the Bretton Woods Conference, proposed introducing government policies to promote aggregate demand, which would avoid economic downturns and foster global economic stability and peace.

\section{ii. International Monetary Fund, World Bank, \& the World Trade Organization}

This overarching need to preserve global economic stability, at the Bretton Woods Conference, gave birth to the IMF and the World Bank, with a similar understanding that an international institution regulating trade should also be effectuated to complement the aforementioned institutions. ${ }^{11}$ While the International Trade Organization was never born, it begot the General Agreement on Tariffs and Trade (hereinafter "GATT"), which ultimately evolved into the WTO.12 The IMF was responsible for "ensuring global economic stability," as the cooperating nations saw "collective action at the global level" necessary to economic security. ${ }^{13}$ The mandate of the World Bank was to provide capital to Japan and the war-torn nations of Europe to reconstruct their economies..$^{14}$

\footnotetext{
${ }^{9}$ Peter Muchlinski, Multinational Enterprises and the Law, 2d ed (New York: Oxford University Press Inc, 2007) at 15-16 [Muchlinski]. Besides Great Britain, other European nations, becoming assimilated into the German war effort, ceased trading as independent, sovereign states.

${ }^{10}$ Joseph Stiglitz, Globalization and its Discontents (New York: W.W. Norton \& Co, 2002) at 11 [Stiglitz].

${ }^{11}$ Bossche, supra note 8 at 79.

12 Ibid at 85; The World Trade Organization was born pursuant to an eight-year negotiation between 123 countries, resulting in the Marrakesh Agreement Establishing the World Trade Organization (hereinafter "WTO Agreement"), coming into effect on 1 January 1995, at 84-85. I must clarify that the GATT did not come into force until 30 October 1947 when a Preparatory Committee originally met to negotiate a Charter for an International Trade Organization (hereinafter "ITO"), at 79. However, the ITO never came into effect as it did not garner support from the United States, at 79-80.

${ }^{13}$ Stiglitz, supra note 10 at 11-12.

${ }^{14}$ Ibid at 10.
} 
The precursor of the WTO, the GATT, saw exponential success in reducing tariffs for the freer movement of goods across borders. ${ }^{15}$ "With a view to achieving greater coherence in global economic policy-making," pursuant to Article III:5, the WTO works with the IMF and the World Bank to maintain free and predictable flow of goods between nations. ${ }^{16}$ The IMF, World Bank, and the WTO are the three principal institutions credited with the proliferation and governance of free trade and globalization, driven by technology and the liberalization of trade and foreign direct investment. ${ }^{17}$

In summation, nearing the first half of the $20^{\text {th }}$ century, the political and economic order of the world was in disarray, due to the Great Depression and the Second World War. The United States, guided by liberal economic beliefs and convinced that free trade was the solution, recommended reducing barriers to trade. I remain doubtful whether I can emphasize anymore than I already have of the impact the IMF, World Bank, and the GATT have had on the liberalization of trade. The concerted effort in reducing trade barriers to sustain global economic stability generated the most extensive form of global economic cooperation. This was at first, led by States under Keynesianism, and later by MNEs when States adopted neoliberalism, a distinction I elaborate upon below. Overall, the harmony resulting from cooperating economies made global trade normative, with technology and the lowered price in transportation giving rise to the most powerful force heretofore - globalization. ${ }^{18}$

\footnotetext{
15 Ibid at $15-16$.

${ }^{16}$ Marrakesh Agreement Establishing the World Trade Organization, 15 April 1994, 1867 UNTS 154, at Art III:5 (entered into force 1 January 1995).

17 Stiglitz, supra note 10 at 10 \& 21; Martin Wolf, "Globalization in a Time of Transition" Financial Times (16 July 2013), online: FT <http://www.ft.com/intl/cms/s/0/9545cd9e-ed3c-11e2-ad6e-00144feabdc0.html\#axzz44LIF5rli> [Wolf].

${ }^{18}$ Bossche, supra note 8 at 4. Also see Wolf, ibid; I have provided the definition of 'globalization' infra at 30-31.
} 
MNEs, primarily headquartered within the United States, gained overnight success because of globalization. Facilitated by the Marshall Aid, which is a paradigm of Keynesianism, American MNEs emerged in their objective to reconstruct Europe's economy. ${ }^{19}$ Since MNEs arose because of globalization, I will discuss them simultaneously, which will illuminate the primary reason MNEs relocate manufacturing overseas. As in, this is principally done to capitalize on the inexpensive labor force in another country to retain a competitive advantage. Therefore, the product can be produced and transported to another country inexpensively, and sold at a significantly higher price, allowing the MNE to profit greatly. ${ }^{20}$ Globalization, and the subsequent adoption of neoliberal policies by the major economic regions of the world, which I will explain below, has permitted MNEs to accumulate unparalleled power. ${ }^{21}$

\section{B - FALL OF BARRIERS IS TO THE RISE OF MULTINATIONAL ENTERPRISES}

For the sake of convenience, I quote again that an MNE consists of companies established in more than one country, usually under the control of a parent company, that are linked by coordinating their operations in various ways. ${ }^{22}$ While it has been said that MNEs were first established in the $16^{\text {th }}$ and $17^{\text {th }}$ centuries by European colonial trading companies, the majority of economists and business historians agree that the modern MNE emerged after

\footnotetext{
${ }^{19}$ Muchlinski, supra note 9 at 16.

${ }^{20}$ Lena Ayoub, “Nike Just Does It — And Why the United States Shouldn't: The United States' International Obligation to Hold MNCs Accountable for their Labor Rights Violations Abroad" (1998-1999) 11 DePaul Bus LJ 395 at 395 [Ayoub]; Also see Keith Cowling \& Roger Sugden, Transnational Monopoly Capitalism (New York: St. Martin's Press, 1987) at 16-22; Also see Alison Gormley, "The Underground Exposed: The United States Corporations' Use of Sweatshops Abroad, and the Abuse of Women” (2001-2002) 25 Suffolk Transnat'1 L Rev 109 at 130 [Gormley]; For the definition of "competitive advantage," see infra at note 31.

${ }^{21}$ Carlos Vázquez, "Direct vs. Indirect Obligations of Corporations Under International Law” (2004-2005) 43 Colum J Transnat'1 L 927 at 948 [Vázquez].

22 "OECD Guidelines for Multinational Enterprises: 2011 Edition" OECD (2011), online: Organization for Economic Cooperation and Development $<$ http://www.oecd.org/corporate/mne/48004323.pdf $>$ at 17; Refer to notes $27 \& 28$, supra at Chapter 1.
} 
$1850 .{ }^{23}$ At the same time, limited liability was granted to MNEs, which facilitated their growth and I will discuss this below. The rise of MNEs has been divided into three periods, with an unsaid fourth period, divided by the First and Second World Wars. ${ }^{24}$ The first period, between 1850 to 1914, saw the rise of British MNEs; while the second period, between 1918 to 1939, led to barriers to trade because of economic instability. ${ }^{25}$ The collapse of the international capital market induced the Great Depression, leading numerous countries to nationalize economies, and the Second World War only frustrated growth. ${ }^{26}$

The third period, from 1945 to 1990, saw an unprecedented growth of MNEs, primarily from the United States up until 1975, at which point European MNEs became competitive. ${ }^{27}$ Marshall Aid was welcomed by European countries, as investment from the United States improved Europe's standard of living and also increased the number of American MNEs. From 1990 onwards, we are currently witnessing the fourth period of MNE growth. This is characterized by global chains of production and linked subcontractors, which I explain in the succeeding paragraph. ${ }^{28}$ This gave rise to "global production networks" between firms and

\footnotetext{
${ }^{23}$ Muchlinski, supra note 9 at 8-9.

${ }^{24}$ Ibid at 9; For an overview of the historical literature on the multiplication of MNEs, see Alan Rugman \& Thomas Brewer, eds, Oxford Handbook of International Business (Oxford: Oxford University Press, 2001) at 1-24; Also see Geoffrey Jones, Multinationals and Global Capitalism: From the Nineteenth to the Twenty First Century (Oxford: Oxford University Press, 2004); For a detailed account of the rise of American MNEs, see Mira Wilkins, The Emergence of Multinational Enterprise: American Business Abroad from the Colonial Era to 1914 (Cambridge, MA: Harvard University Press, 1970).

${ }^{25}$ Muchlinski, supra note 9 at 10-12.

${ }^{26}$ Ibid at 13; Videlicet, Italy and Germany adopted fascist economic policies, whereby nationalizing control over manufacturing, and acquiring foreign territory for political and economic expansion, at 13.

27 Ibid at 15-17.

${ }^{28}$ Ibid at 21-23; When the GATT transformed into the WTO, consisting of 30 comprehensive agreements extending to 30,000 pages, it essentially provided a forum for countries engaging in trade negotiations to further enhance the freer movement of goods across borders, at "The WTO Agreements" World Trade Organization (2016), online: World Trade Organization < https:/www.wto.org/english/thewto_e/whatis_e/inbrief_e/inbr03_e.htm>.
} 
subcontractors, where "subsidiarization" gained popularity and MNEs began outsourcing

production to third parties. ${ }^{29}$

\section{i. The Economic Reasons for the Growth of Multinational Enterprises}

The idea that MNEs should outsource — buying goods and services from a supplier that offers the desired product inexpensively $y^{30}$ — production for profit maximization was put forward by Stephen Hymer. He hypothesized that firms would gain a competitive advantage if they internationally integrated their operations. ${ }^{31}$ Outsourcing progressed into subcontracting, allowing MNEs to obtain higher profits. ${ }^{32}$ These processes have been supported by the Heckscher-Ohlin Model, which builds upon Ricardo's theory of comparative advantage. It theorizes that countries will profit if they specialize in producing goods for which the country has ample input resources. ${ }^{33}$ It was then Peter Buckley and Mark Casson who refined Ronald Coase's theory of internalization, saying MNEs grow when there is an increased flow of goods between national borders among the affiliates of the MNE. ${ }^{34}$

Assisted by the near elimination of trade barriers, MNEs experienced monumental growth, relocating manufacturing overseas to developing regions, such as Latin America, Asia,

\footnotetext{
${ }^{29}$ Muchlinski, supra note 9 at 23-24; Also see Aaditya Mattoo \& Sacha Wunsch-Vincent, "Pre-empting Protectionism and Outsourcing: The GATS and Outsourcing” (2004) 7 J Int'l Econ L 765.

${ }^{30}$ Black et al, supra note 3 sub verbo "outsourcing"; Gormley, supra note 20 at 130.

${ }^{31}$ Muchlinski, supra note 9 at 26; A "competitive advantage" is an advantage a firm possesses over its competitors, from, inter alia, efficient production techniques and consumer loyalty, which delivers a higher profit to the firm than that obtained by its competitors, at Black et al, supra note 3 sub verbo "competitive advantage."

${ }^{32}$ Laura Ho, Catherine Powell \& Leti Volpp, “(Dis)assembling Rights of Women Workers Along the Global Assembly Line: Human Rights and the Garment Industry” (1996) 31 Harv CR-CLL Rev 383 at 386 ;

'Subcontracting' is when manufacturers contract the elements of production to a party, and the original party contracts the received contract to another contractor.

${ }^{33}$ Muchlinski, supra note 9 at 26.

${ }^{34} \mathrm{Ibid}$; "Internalization," simply stated, is when firms encounter high transaction costs in the procurement of supplies and the distribution of final products, it may be able to reduce the said high transaction cost by carrying out those transactions within the firm — as in, the firm "internalizes" the transactions, ibid at 28.
} 
Southeast Asia, and South Asia to capitalize on the inexpensive and abundant labor force. Thus, MNEs would import the finished goods to sell domestically for maximum profit. ${ }^{35}$ This point will be illuminated when I discuss the RMG industry in Bangladesh below, demonstrating how its affordable labor force appealed to Western manufacturers. Nonetheless, as MNEs orchestrated integrated international operations, the movement of goods across national boundaries truly became global. Advanced by the diminishing cost of technology and communication, globalization followed.

\section{ii. Integrated Supply Chains}

By the 1970s, MNEs focused their attention on reducing costs in logistics and integrating supply chains, which is a network between the company and the supplier to produce and distribute products. ${ }^{36}$ For example, in 1955, Unilever said that a one-day delay in transporting finished goods amounted to a daily loss of $£ 5$ million, which equalled $£ 100$ million as of 2010 . Therefore, as MNEs transcended national boundaries to capitalize on the inexpensive labor force, they also realized that the lower cost of transportation would benefit them because they could transport products to more countries, sell the products at a competitive price, and make a profit. ${ }^{37}$ Led by MNEs, this growing importance of supply chains has transformed it into accounting for $80 \%$ of world trade and $60 \%$ of global production. ${ }^{38}$ However, MNEs directly employ only $6 \%$ of those working in their supply chains, whereas the others constitute the

\footnotetext{
${ }^{35}$ Ayoub, supra note 20 at 395; Also see Keith Cowling \& Roger Sugden, Transnational Monopoly Capitalism (New York: St. Martin's Press, 1987) at 16-22; Also see Gormley, supra note 20 at 130.

${ }^{36}$ Donald Waters, Supply Chain Management: An Introduction to Logistics, 2d ed (New York: Palgrave Macmillan, 2009) at 34 [Waters].

37 Ibid at 41-42.

38 "Supply Chains Resources Hub" International Trade Union Confederation, online: ITUC <http://www.ituccsi.org/supply-chains-resources-hub?lang=en>.
} 
"hidden workforce" of global production. ${ }^{39}$ Though MNEs do not directly employ those who work in their supply chains, in Chapter 4, I will demonstrate how an MNE can nonetheless be held liable for injuries occurring in its supply chain based on the premise that the MNE (LCL) and its supplier (Rana Plaza) were involved in the same economic enterprise.

\section{iii. The Legal Reasons for the Growth of Multinational Enterprises}

While reducing barriers to trade allowed MNEs to grow, their development was facilitated by a political concept — limited liability. ${ }^{40}$ Salomon is credited with granting legal personality to corporations; yet, corporations inherited the trait of limited liability nearly one hundred years earlier in the United States, and it became the generally accepted rule in Canada in 1850 and for England in $1855 .{ }^{41}$ Limited liability speaks of the liability of a corporation that is limited because of its persona ficta status. ${ }^{42}$ As in, a shareholder in a corporation is not liable for the debts the corporation incurs for more than the amount the shareholder has invested even if the corporation becomes insolvent. ${ }^{43}$

Frank Easterbrook and Daniel Fischel suggest that limited liability is conducive to the growth of economic activity, and that the modern MNE could not exist without this bedrock

\footnotetext{
${ }^{39}$ Ibid.

40 Phillip Blumberg, “Accountability of Multinational Corporations: The Barriers Presented by Concepts of the Corporate Juridical Entity” (2000-2001) 24 Hastings Int'1 \& Comp L Rev 297 at 301 [Blumberg: Barriers].

${ }^{41}$ Phillip Blumberg, "Limited Liability and Corporate Groups” (1985-1986) 11 J Corp L 573 at 585 \& $592-594$ [Blumberg: Limited Liability]. For a comprehensive overview of the historical rise of limited liability in England, see 578-585; For the rise of limited liability in the United States, see 587-594.

${ }^{42}$ Frank Easterbrook \& Daniel Fischel, "Limited Liability and the Corporation” (1985) 52 U Chicago L Rev 89 at 89 [Easterbrook \& Fischel].

${ }^{43}$ Ibid at 89-90; See generally Harry Glasbeek, Wealth by Stealth: Corporate Crime, Corporate Law, and the Perversion of Democracy (Toronto: Between the Lines, 2002) at 8-15; Again, a shareholder can be a person or another corporation.
} 
principle. ${ }^{44}$ Limited liability is inextricably intertwined with the rise of corporations. As shareholders were interested in investing in corporations, they demanded protection to their personal wealth. ${ }^{45}$ That is, shareholders were scared that creditors would pursue litigation against them if the corporation could not pay its debts. For this reason, they did not want to invest in corporations. ${ }^{46}$ However, if shareholders did not invest in corporations, the company could not grow because they would lack the necessary capital. Therefore, limited liability appealed to shareholders because it protected their personal wealth from creditors even if the corporation became insolvent. Thus, this induced shareholders to invest in corporations. ${ }^{47}$

Led by the United States in 1890, corporations were permitted to hold shares in another corporation, marking the emergence of subsidiaries that were also protected by limited liability. ${ }^{48}$ While limited liability allowed corporations to become the dominant form of business, allowing corporations to hold shares in another corporation is what permitted the proliferation of MNEs (through subsidiaries), forever changing the visage of modern business.

\section{iv. Globalization's Effects on Multinational Enterprises}

Globalization is the closer integration of people and countries due to reduced costs of communication, transportation, and barriers to trade. This has led to new institutions being formed and crossing borders to work with existing ones. It is a force that affects jobs, food,

\footnotetext{
${ }^{44}$ Frank Easterbrook \& Daniel Fischel, The Economic Structure of Corporate Law (Cambridge, MA: Harvard University Press, 1991) at 41-44; Also see Henry Manne, "Our Two Corporation Systems: Law and Economics" (1967) 53 Va L Rev 259 at 259.

${ }^{45}$ Blumberg: Barriers, supra note 40 at 301.

${ }^{46}$ Ibid; Blumberg: Limited Liability, supra note 41 at 592-593.

${ }^{47}$ Blumberg: Barriers, supra note 40 at 301.

48 Phillip Blumberg, "The Increasing Recognition of Enterprise Principles in Determining Parent and Subsidiary Corporation Liabilities" (1995-1996) 28 Conn L Rev 295 at 298.
} 
health, education, and leisure time of people everywhere. ${ }^{49}$ As Antony Hopkins explains, while the term 'globalization' is new, political boundaries have always been crossed due to trade, financial flows, and migration. ${ }^{50}$ Nonetheless, contemporary globalization is so powerful that decisions in one part of the world affect persons who are far away. Its effects are quickly felt because of new modes of communication and transportation.

This phenomenon has diffused ideas, created interdependence, increased the number of MNEs, and has compressed the globe. ${ }^{51}$ Whether trade or finance, globalization has increased their activities. ${ }^{52}$ MNEs are a powerhouse in globalization, as they move capital, goods, and technology across national borders, establishing subsidiaries in, or outsourcing production to, numerous nations. ${ }^{53}$ Essentially, the rise of MNEs exists in a symbiotic relationship to globalization, as one would not continue without the other. Globalization is an irreversible process; or, is reversible only by harming the economy of a nation, as both developed and developing countries profit from globalization, chiefly led by exports.

\section{v. Branding}

While globalization's ability to reduce costs of transportation made outsourcing by MNEs common, it also facilitated the growth of integrated supply chains. ${ }^{54}$ As I discuss further below,

\footnotetext{
${ }^{49}$ Sitglitz, supra note 10 at 9; Bossche, supra note 8 at 3.

${ }^{50}$ Susan Marks \& Andrew Clapham, International Human Rights Lexicon (Toronto: Oxford University Press, 2005) at 180 [Marks \& Clapham]; Amartya Sen claims that, inter alia, the printing press, crossbow, gunpowder, and the rotary fan were invented in China, while the decimal system originated in India and disseminated to the rest of the world, at Amartya Sen, The Globalization Reader, 5th ed by Frank Lechner \& John Boli (Hoboken, NJ: WileyBlackwell, 2015) at 19-20 [Lechner \& Boli].

${ }^{51}$ Roland Robertson, Globalization: Social Theory and Global Culture (London, UK: Sage, 1992) at 8.

52 Marks \& Clapham, supra note 50 at 181-182.

${ }^{53}$ Stiglitz, supra note 10 at 10.

${ }^{54}$ Robert Phillips and Craig Caldwell, "Value Chain Responsibility: A Farewell To Arm's Length" (2005) 110 Bus \& Soc'y Rev 345 at 350-351.
} 
laborers in the RMG sector in Bangladesh are paid \$38 monthly; as in, they receive $12 \varnothing$ per shirt. ${ }^{55}$ Currently, it costs $\$ 1$ for a polo shirt to be shipped from Bangladesh to Canada, while the overall cost for its fabrication is $\$ 5.67$. However, the same polo shirt is sold for a minimum of $\$ 14$ in Canada, allowing a profit margin of $209 \% .{ }^{56}$ Customers are willing to pay the inflated price because of branding, which is a name, design, or a mark on a product that enhances its value beyond the product's actual purpose. ${ }^{57}$ That is, customers trust the company's products because it has maintained consistent quality. Therefore, by relying on a positive, consistent, and accessible brand image, companies produce goods at a lesser cost, but inflate their prices because consumers will purchase their products and the companies profit substantially thereby. ${ }^{58}$

\section{vi. Neoliberalism: Political Apparatus of Globalization}

Contemporary globalization is interwoven with the world's major economic regions adopting neoliberal policies. ${ }^{59}$ Neoliberalism, which the United States adopted in the late 1970s, is a theory of political and economic practices suggesting financial prosperity to lie in economic freedoms. Therefore, it is characterized by free trade, free markets, and private property rights. ${ }^{60}$ It further proposes that the State should not be involved in the market beyond creating an environment conducive to the growth of business. Rather, the State should form institutions such

\footnotetext{
${ }^{55}$ Rosemary Westwood, “What Does that \$14 Shirt Really Cost?” Maclean's (1 May 2013), online: Rogers Media $<$ http://www.macleans.ca/economy/business/what-does-that-14-shirt-really-cost/>.

56 "Benchmarking the Competitiveness of Nicaragua's Apparel Industry" O'Rourke Group Partners LLC (April 2011), online: O’Rourke Group Partners <http://tradebridgeconsultants.com/documents/Nicaragua-Benchmarkingthe-competitiveness-of-Nicaraguas-Apparel-Industry.pdf/> at 18; See Appendix C, infra at page 158.

57 Peter Farquhar, "Managing Brand Equity" (1989) 1 Marketing Research 24 at 25 [Farquhar]; Also see Cathy Cobb-Walgren, Cynthia Ruble \& Naveen Donthu, "Brand Equity, Brand Preference, and Purchase Intent" (1995) 24 J Advertising 25.

${ }^{58}$ Farquhar, ibid at 27-29.

${ }^{59}$ Marks \& Clapham, supra note 50 at 181.

${ }^{60}$ David Harvey, A Brief History of Neoliberalism (New York: Oxford University Press Inc, 2005) at 2-3 [Harvey].
} 
as the military, police, and legal mechanisms, to preserve private property rights. ${ }^{61}$ Beyond this involvement, neoliberalism disapproves of government intervention in markets. As in, neoliberalism is the antithesis of Keynesianism; whereas the latter favors the involvement of government in the market to stimulate aggregate demand, neoliberalism does not.

Neoliberalism supports trade liberalization and separating the market from the State. Once States succeeded in reducing barriers to trade and the world environment was favorable to global business, neoliberalism appealed to human intuition. Thus, it became a desirous framework of the IMF, World Bank, and the GATT, which further increased global trade. MNEs profited the most from these policies, as the glass ceiling inhibiting their growth disintegrated. ${ }^{62}$

Since the conclusion of the Second World War, tenets of free trade have directed countries to preserve global economic stability. While this promoted international trade, it was the adoption of neoliberal policies that truly helped global trade and MNEs grow, as private property rights prevailed over government intervention in the market. Friedrich Hayek, whose ideas garnered monumental popularity during the 1970s, urged for maximum economic freedom for individuals and businesses. ${ }^{63}$ Another popular statement, which became convention, was delivered by Milton Friedman declaring that the "one and only one social responsibility of business" is the use of "its resources [...] to increase its profits." ${ }^{64}$ The confluence of factors global interest in reducing trade barriers, adopting neoliberalism, and this notion that

\footnotetext{
${ }^{61} \mathrm{Ibid}$ at 2.

${ }^{62}$ Ibid at 3-5.

${ }^{63}$ Friedrich Hayek, The Road to Serfdom (London: George Routledge \& Sons, 1944) at 15, 17-18 \& 124; Also see Friedrich Hayek, The Constitution of Liberty (Chicago: University of Chicago Press, 1960), where Hayek argued that the battle of ideas is key and that liberalism will prevail over Marxism, socialism, and Keynesianism.

${ }^{64}$ Milton Friedman, Capitalism and Freedom (Chicago: University of Chicago Press, 2002) at 133; This notion that corporations ought to only maximize profits became known as the "Friedman Doctrine."
} 
corporations should maximize profits - gave rise to outsourcing, which evolved into

subcontracting. Outsourcing and subcontracting also serve the critical aspect of shielding the manufacturer from liability, which I will explain in the following Chapter. ${ }^{65}$ Thus, MNEs transcended national boundaries, generating revenues greater than numerous nations. ${ }^{66}$

Since I have provided context to the political and economic climate following 1945, and the subsequent rise of MNEs, I will now discuss the impact of globalization on Bangladesh and trace the country's rise in global garment production. This will demonstrate globalization's impact on Bangladesh. As industries involved in chemical production, extractive sectors, and garments moved overseas, the RMG sector was especially susceptible to globalization. Trends in fashion change quickly and fabric requires human labor because it is immune to mechanization. ${ }^{67}$ Bangladesh, with a population of 159.1 million, offered an abundant and inexpensive labor force, and since garment employees are paid monthly wages of $\$ 38$, the country caught the attention of numerous manufacturers. ${ }^{68}$ Manufacturers quickly outsourced production to Bangladesh and the country became the "hot spot" for apparel sourcing since the mid-1980s. ${ }^{69}$ As in, the ingredients necessary for MNEs to maximize profits were all found in Bangladesh.

\footnotetext{
${ }^{65}$ Lora Jo Foo, “The Vulnerable and Exploitable Immigrant Workforce and the Need for Strengthening Worker Protective Legislation” (1994) 103 Yale LJ 2179 at 2185

66 José Antunes, “The Liability of Polycorporate Enterprises” (1998-1999) 13 Conn J Int'1 L 197 at 203 [Antunes]; Also see Vázquez, supra note 21 at 948.

${ }^{67}$ Maria Gillen, “The Apparel Industry Partnership's Free Labor Association: A Solution to the Overseas Sweatshop Problem or the Emperor's New Clothes?” (1999-2000) 32 NYUJ Int'1 L \& Pol 1059 at 1059.

68 "Bangladesh" The World Bank (2016), online: The World Bank Group: IBRD. IDA < http://www.worldbank.org/ en/country/bangladesh>; Jim Yardley, "Bangladesh Takes Step to Increase Lowest Pay” The New York Times (4 November 2013), online: The New York Times <http://www.nytimes.com/2013/11/05/world/asia/bangladesh-takesstep-toward-raising-38-a-month-minimum-wage.html?_r=1>

${ }^{69}$ Achim Berg, Saskia Hedrich \& Thomas Tochtermann, "Bangladesh: The Next Hot Spot in Apparel Sourcing?" McKinsey \& Company (March 2012), online: McKinsey \& Company <http://www.mckinsey.com/industries/ consumer-packaged-goods/our-insights/bangladesh-the-next-hot-spot-in-apparel-sourcing $>$ [Berg et al].
} 


\section{C - HISTORY OF BANGLADESH'S RISE IN GARMENT PRODUCTION}

As I have described above, after the conclusion of the Second World War, barriers to trade were being disassembled; yet, the RMG sector was heavily regulated pursuant to the MultiFiber Arrangement (hereinafter “MFA"), which was in effect from 1974 to 1994, between GATT contracting parties..$^{70}$ The $M F A$ imposed import quotas for textiles on developing nations, such as South Korea. ${ }^{71}$ However, South Korea ingeniously circumvented provisions of the MFA by requesting the help of Bangladesh, which was unaffected by the import restrictions because Bangladesh was held to be one of the 48 Least Developed Countries. ${ }^{72}$ As in, the MFA restrictions only applied to developing countries, and since Bangladesh was not a developing country, no restriction was imposed. Thus, because South Korea employed the help of Bangladesh, the economic culture of the latter country has forever changed, even though $31.5 \%$ of the country's population currently lives in poverty. ${ }^{73}$

To provide context, I add that South Korea was the contractor to whom the manufacturer outsourced production, and in seeking Bangladesh's help, South Korea subcontracted that original contract. I will explain subcontracting's legal relevance in Chapter 4.

70 “Textiles Monitoring Body (TMB): The Agreement on Textiles and Clothing" World Trade Organization (2016), online: WTO < https://www.wto.org/english/tratop_e/texti_e/texintro_e.htm> [TMB]; Alexandra Caleca, "The Effects of Globalization on Bangladesh's Ready-Made Garment Industry: The High Cost of Cheap Clothing" (2014) 40 Brook J Int'l L 279 at 284 [Caleca].

${ }^{71}$ Caleca, ibid.

72 "List of Least Developed Countries (as of 16 February 2016)" United Nations Department of Economic And Social Affairs Development Policy and Analysis Division Committee for Development Policy (16 February 2016), online: United Nations <http://www.un.org/en/development/desa/policy/cdp/ldc/ldc_list.pdf $>$. As of 2016, Bangladesh is still one of the 48 least developed countries. For the sake of clarification, I make no distinction between "least developing countries" and "developing countries," and I use the latter term to encompass Bangladesh, unless otherwise specified.

${ }^{73}$ Caleca, supra note 70 at 285; Lea Gimenez et al, "Bangladesh Poverty Assessment: Assessing a Decade of Progress in Reducing Poverty, 2000-2010" The World Bank Bangladesh Development Series Paper No. 31 (June 2013), online: The World Bank <http://www-wds.worldbank.org/external/default/WDSContentServer/WDSP/IB/ 2013/06/19/000333037_20130619115421/Rendered/PDF/785590NWP0Bang00Box0377348B0PUBLIC0.pdf $>$ at 1 [Gimenez et al]. 
In comparison to the $31.5 \%$ that currently lives in poverty, after Bangladesh secured its independence from Pakistan in $1971,70 \%$ of its citizens were living below the poverty line. ${ }^{74}$ In 1972, Bangladesh saw a gross domestic product (hereinafter "GDP") growth of $-14.74 \%$, because it relied on rain-fed agriculture and supported the $61 \%$ of its agricultural labor force with defunct technology. In 1977, Daewoo Group, a South Korean MNE, partnered with and established a firm in Bangladesh, Desh Garments Limited, to produce five million pieces of garments annually to export them. ${ }^{75}$ Daewoo provided free training and modern equipment to Bangladeshi nationals while Bangladesh provided cheap labor as quid pro quo. ${ }^{76}$ Partnering with firms in Bangladesh permitted South Korea to bypass quota provisions of the MFA, while also profiting from Bangladesh's inexpensive and abundant labor force. Essentially, both countries benefitted from this cooperation, as South Korea could export more articles of clothing, and Bangladesh promoted employment locally. Consequently, 1977 marked the breakthrough year for Bangladesh's RMG industry. ${ }^{77}$

In 1978, less than twelve garment factories were operational, with capacity to produce eight to nine million units. ${ }^{78}$ By 1981, one hundred garment factories were functioning, and by

\footnotetext{
${ }^{74}$ Gimenez et al, ibid.

${ }^{75}$ Mohammad Yunus \& Tatsufumi Yamagata, "The Garment Industry in Bangladesh" Institute of Developing Economies (March 2012), online: Institute of Developing Economies: Japan External Trade Organization <http:// www.ide.go.jp/English/Publish/Download/Report/2011/pdf/410_ch6.pdf $>$ at 4 [Yunus]. For general URL, see $<$ http://www.ide.go.jp/English/Publish/Download/Report/2011/2011_410.html $>$.

${ }^{76}$ Naila Kabeer \& Simeen Mahmud, "Rags, Riches and Women Workers: Export-Oriented Garment Manufacturing in Bangladesh" Women in Informal Employment: Globalizing and Organizing (January 2004), online: WIEGO $<$ http://wiego.org/sites/wiego.org/files/publications/files/Kabeer-Mahmud-Export-Oriented-GarmentBangladesh.pdf $>$ at 136; For general URL, see $<$ http://wiego.org/publications/rags-riches-and-women-workersexport-oriented-garment-manufacturing-bangladesh $>$.

77 James Heitzman \& Robert Worden, "Bangladesh: A Country Study" Federal Research Division: Library of Congress (1989), online: United States Government $<$ http://memory.loc.gov/master/frd/frdcstdy/ba/ bangladeshcountr00heit/bangladeshcountr00heit.pdf $>$ at 106 .

${ }^{78}$ Dean Spinanger, "Will the Multi-Fibre Arrangement Keep Bangladesh Humble" (1987) 10 World Economy 75 at 78 [Spinanger].
} 
1985, 384 factories were producing 300 million units annually. ${ }^{79}$ RMG then became

Bangladesh's principal export and one of its key drivers of economic growth, as entrepreneurs in

Bangladesh foresaw the possibility of profits from this heretofore nascent industry, constructing

facilities in Dhaka and Chittagong forthwith. ${ }^{80}$

\section{i. Contribution of the Government of Bangladesh}

In developing countries, it is common to see the government being unable to create an environment conducive to emerging industry. ${ }^{81}$ Surprisingly, Bangladesh was an exception.

Though Bangladesh inherited policies of government intervention in the market from Pakistan, after a coup d'etat in 1975, the GOB adopted a liberal approach. This was accompanied by issuing licenses to numerous entrepreneurs in importing duty-free machinery needed in garment production. ${ }^{82}$ The GOB promoted investment, established export processing zones (hereinafter "EPZ"; I discuss this further in Chapter 4), provided tax incentives for manufacturing firms, and sought to reduce barriers to external markets by becoming a signatory to the GATT on 16 December $1972 .{ }^{83}$ Ultimately, this began the groundwork for creating a strong manufacturing edifice for the country's economy ${ }^{84}$ To contextualize, the GOB's endorsement of a liberal

79 "Trade Information: Membership and Employment" Bangladesh Garment Manufacturers and Exporters Association (22 February 2016), online: Bangladesh Garment Manufacturers and Exporters Association: Towards a Sustainable Garments Industry <http://www.bgmea.com.bd/home/pages/tradeinformation> [BGMEA: Membership].

${ }^{80}$ Caleca, supra note 70 at 285; Also see Gimenez et al, supra note 73 at $2 \& 71$.

${ }^{81}$ Yunus, supra note 75 at 4.

${ }^{82}$ Ibid.

${ }^{83}$ UNCTAD Secretariat, "The Least Developed Countries 1999 Report" United Nations Conference on Trade and Development (1999), online: United Nations Conference on Trade and Development $<$ http://unctad.org/en/Docs/ ldc1999_en.pdf> at 101; "Understanding the WTO: The Organization, Members and Observers" The World Trade Organization (2016), online: WTO < https://www.wto.org/english/thewto_e/whatis_e/tif_e/org6_e.htm> [WTO: Members]; Also see Nurul Momen, "Implementation of Privatization Policy: Lessons from Bangladesh" The Innovation Journal: The Public Sector Innovation Journal (2007), online: Innovation <http://www.innovation.cc/ scholarly-style/momen_privatization4e.pdf>.

${ }^{84}$ Yunus, supra note 75 at 2. 
approach occurred concurrently with the increasing global popularity of neoliberalism.

Bangladesh truly became an ocean of untapped resource, offering its abundant and cheap labor

force ripe for the mutual benefit of MNEs, who sought profit maximization, and the country, who wished to exhume itself from dire poverty. ${ }^{85}$

\section{ii. An Insurmountable International Predicament}

The growing RMG industry of Bangladesh was met with a barrier, as the United Kingdom, France, Canada, and the United States foisted import quotas on Bangladesh in accordance with the $M F A$ provisions. ${ }^{86}$ Fortunately for Bangladesh, the $M F A$ was repealed and replaced with the Agreement on Textiles and Clothing (hereinafter "ATC") in 1995, which was included under Annex 1 of the WTO Agreement. ${ }^{87}$ It was predicted that the $A T C$ would be harmful to the RMG industry of Bangladesh because, in a "quota-free world market after 2004," Bangladesh may not be able to compete against other developing countries when the $A T C$ is rendered moot. ${ }^{88}$ The United Nations, along with other experts, predicted that over a million workers from garment factories would be dismissed because Bangladesh is not qualified to contend with the cheap labor of China. ${ }^{89}$

\footnotetext{
${ }^{85}$ For an excellent overview of globalization's effect on Bangladesh's RMG industry, see Anam Ullah, “Garment Industry in Bangladesh: An Era of Globalization and Neo-Liberalization" Middle-East Journal of Business (April 2015), online: Middle-East Journal of Business <http://www.mejb.com/upgrade_flash/April2015/ Neoliberalism.htm>.

${ }^{86}$ Spinanger, supra note 78 at 79.

${ }^{87}$ TMB, supra note 70; Also see "Legal Texts: The WTO Agreements" World Trade Organization, online: World Trade Organization <https://www.wto.org/english/docs_e/legal_e/final_e.htm>. Refer to note 12 supra.

${ }^{88}$ Montfort Mlachila \& Yongzheng Yang, "The End of Textile Quotas: A Case Study of the Impact on Bangladesh" International Monetary Fund Working Paper (2004), online: International Monetary Fund <https://www.imf.org/ external/pubs/ft/wp/2004/wp04108.pdf> at 4.

${ }^{89}$ Christoph Ernst, Alfons Ferrer \& Daan Zult, "The End of the Multi-Fibre Arrangement and its Implications for Trade and Employment" International Labour Organization (2005), online: International Labour Organization $<$ http://ilo.org/wcmsp5/groups/public/---ed_emp/---emp_elm/documents/publication/wcms_114030.pdf > at 9.
} 
The $A T C$, however, had a salutary effect on Bangladesh's RMG sector. While Bangladesh would now compete with other developing nations, the country would enjoy "quota-free" access to foreign markets, which was the peripeteia in its fortune. ${ }^{90}$ Subsequently, when Bangladesh became a member of the WTO, the European Union granted Bangladesh duty-free and quotafree access to its markets for nearly all goods pursuant to its Everything but Arms (hereinafter "EBA") initiative ${ }^{91}$ The $E B A$ is similar to the Generalized System of Preferences of the United States, Japan, and Canada, which similarly permits Bangladesh duty-free access to markets of the respective countries, further facilitating the growth of its RMG sector. ${ }^{92}$

Therefore, despite projections to the contrary, the RMG sector of Bangladesh saw continued growth. Unaffected by international competition, Bangladesh opened 343 new garment factories for the year 1994 to $1995 .{ }^{93}$ Furthermore, from 1995 to 2005, the RMG industry hired one million additional employees to work at the 1,925 newly opened garment factories. Therefore, the $A T C$ did not adversely affect Bangladesh's garment industry. By 2005, the RMG sector in Bangladesh had transformed into a "multi-billion-dollar" industry, accounting for $75 \%$ of the nation's earnings that year. ${ }^{94}$

\footnotetext{
${ }^{90}$ Caleca, supra note 70 at 286.

91 WTO: Members, supra note 83; "Bangladesh" European Commission (28 April 2016), online: European Commission <http://ec.europa.eu/trade/policy/countries-and-regions/countries/bangladesh/>; The EBA disallowed duty-free and quota-free access for armaments from Bangladesh.

92 Mustafizur Rahman, "Trade Benefits for Least Developed Countries: the Bangladesh Case" United Nations Department of Economic and Social Affairs (28 July 2014), online: United Nations <http://www.un.org/en/ development/desa/policy/cdp/cdp_background_papers/bp2014_18.pdf $>$ at 12; For a detailed discussion of the United States' Generalized System of Preferences' effect on Bangladesh, see Lisa Clay, "The Effectiveness of the Worker Rights Provisions of the Generalized System of Preferences: the Bangladesh Case Study" (2001) 11 Transnat'l L \& Contemp Probs 175.

${ }^{93}$ BGMEA: Membership, supra note 79.

${ }^{94}$ Caleca, supra note 70 at 287.
} 


\section{iii. A Mentionable Transformation}

As of 2015, the incremental annual growth of Bangladesh's RMG sector has transformed the nation into the second largest RMG exporter in the world, trailing only China. ${ }^{95}$ From January to November 2015, RMG exports earned Bangladesh $\$ 26.6$ billion of the country’s $\$ 172.9$ billion GDP. These numbers account for $81.68 \%$ of the country's total exports and $14 \%$ of national GDP. ${ }^{96}$ Over the course of 44 years, poverty has been alleviated by $40 \%$, GDP has grown annually by five to six percent, leading Kyle Peters to comment on the country's "remarkable progress in reducing poverty." 97

The credit for alleviating poverty is, to a great extent, owed to the country's RMG industry. Though $53.9 \%$ of the country's GDP is acquired from services, industry (consisting of RMG) accounts for $28.9 \%$ of national GDP earnings, representing the second largest source of income for the country. ${ }^{98}$ Earnings from agriculture, which currently retains $47.56 \%$ of the labor force accounts for the remainder of the $17.2 \%$ of Bangladesh's GDP. ${ }^{99}$ The GOB soon realized that the industrial sector was the economy's driver and that agriculture was its past.

\footnotetext{
95 "Improving Working Conditions in the Readymade Garment Industry: Progress and Achievements" International Labour Organization (January 2016), online: International Labour Organization $<\mathrm{http}$ ://www.ilo.org/dhaka/ Whatwedo/Projects/WCMS_240343/lang--en/index.htm> [ILO: Progress].

${ }^{96}$ BGMEA: Membership, supra note 79; "Data: Bangladesh" The World Bank (2016), online: The World Bank: IBRD. IDA < http://data.worldbank.org/country/bangladesh> [World Bank: Data].

${ }^{97}$ Gimenez et al, supra note 73 at 1-2; "Bangladesh and The World Bank Working Together to End Extreme Poverty" The World Bank (27 October 2015), online: The World Bank: IBRD. IDA < http://www.worldbank.org/en/ news/press-release/2015/10/27/bangladesh-and-world-bank-working-together-to-end-extreme-poverty>.

98 "Bangladesh GDP and Economic Data" Global Finance (12 March 2016), online: Global Finance <https:// www.gfmag.com/global-data/country-data/bangladesh-gdp-country-report>; Agriculture contribute to $\$ 28.6$ billion, at Bangladesh Bureau of Statistics, online: Bangladesh Bureau of Statistics $<$ http://www.bbs.gov.bd/ WebTestApplication/userfiles/Image/GDP/GDP_2014-15_Final.pdf $>$ at 1. For general URL, see $<$ http:// www.bbs.gov.bd/PageWebMenuContent.aspx?MenuKey=363>.

${ }^{99}$ Yunus, supra note 75 at 1; Gimenez et al, supra note 55 at 2; "Bangladesh: Decent Work Country Programme, 2012-2015" International Labour Organization (November 2012), online: International Labour Organization $<$ http://www.ilo.org/public/english/bureau/program/dwcp/download/bangladesh.pdf $>$ at 3 [ILO: Employment]; Also see Appendix D, infra at page 159 for easier understanding.
} 


\section{iv. Women Empowerment}

The RMG sector is also responsible for employing four million workers, with $60 \%$ estimated to be women, who have been greatly empowered by said employment and have found a "new identity" in the garment industry in a primarily male-dominated country. ${ }^{100}$ Traditionally, women did not work outside their homes in Bangladesh. ${ }^{101}$ Nonetheless, the growth of garment factories in the 1980 s required more workers in order to meet international demand. It was at this time that women entered the labor force, particularly the garment industry, as it was the only sector capable of providing large-scale employment to women. The employment of women also has the impact of increasing women's education, postponing early marriage, and subsequently, child birth. ${ }^{102}$

\section{v. Bangladesh's Garment Sector will Further Grow}

In addition to the garment sector's earnings, employing and empowering women, a study conducted by McKinsey \& Company in 2010, concludes that $86 \%$ of Chief Purchasing Officers (hereinafter "CPO”) from leading European and American apparel companies, plan on decreasing sourcing from China because of declining profit margins. ${ }^{103}$ For example, the lowest wage paid to an employee in China is $\$ 166$ monthly, and the lowest wage paid to a garment

\footnotetext{
100 ILO: Progress, supra note 95; Jason Motlagh \& Atish Saha, “The Ghosts of Rana Plaza: In Bangladesh, One Year After the Worst Accident in the History of the Garment Industry, Recovery Remains a Fragile Process, Justice Seems Elusive, and Reform has a Long Way to Go" (2014) 90 Va Q Rev 44 at 68.

${ }^{101}$ Filippo Sebastio, "Female Empowerment in the Bangladesh Garment Industry" International Growth Centre (18 November 2014), online: International Growth Centre <http://www.theigc.org/blog/female-empowerment-in-thebangladeshi-garment-industry/>; Also see Gimenez et al, supra note 73 at 71.

102 Gimenez et al, ibid at 3.

103 Berg et al, supra note 69; For the full report, see Achim Berg et al, "Bangladesh's Ready-Made Garments Landscape: The Challenge of Growth" McKinsey \& Company (November 2011), online: McKinsey \& Company $<$ https://www.mckinsey.de/sites/mck_files/files/2011_McKinsey_Bangladesh.pdf $>$.
} 
employee in Bangladesh is $\$ 68$ as of late $2013 .{ }^{104}$ Though $\$ 68$ represents a monthly increase of $\$ 30$ from the previously paid $\$ 38$, Sri Lanka excepted, it is still the lowest wage paid to a garment employee among the 25 apparel-exporting developing countries. This low wage allows MNEs to profit significantly. Therefore, CPOs cite Bangladesh to be the next "hot spot" for apparel sourcing, indicating the potential of the industry's further growth.

In summation, $70 \%$ of the country's population was living below the poverty line in 1971, which lessened to $56.6 \%$ in 1992 , and stands at $31.5 \%$ as of $2010 .{ }^{105}$ The RMG sector employs $17.52 \%$ of the labor force in industry, while also substantially contributing to national GDP and empowering women in the process. ${ }^{106}$ Despite the advantages of globalization, and the expansion of the RMG industry, it is an unfortunate veneer that conceals a gloomy picture of the true nature of the country's garment industry. In 2013, there were 5,876 garment factories in Bangladesh, decreasing to 4,296 in 2015.107 If manufacturers refuse to place orders in Bangladesh, as the Walt Disney Company did in the aftermath of Rana Plaza, it would be overwhelmingly detrimental to the economy of the nation. Since the RMG sector is responsible for exporting $\$ 26.6$ billion worth of merchandise, accounting for $81.68 \%$ of total exports, in a country inundated with poverty, the complete removal of the RMG sector would shatter the edifice upon which its economy is built. ${ }^{108}$

\footnotetext{
104 Malte Luebker, "Minimum Wages in the Global Garment Industry" International Labour Organization Regional Economic and Social Analysis Unit: Research Note (November 2014), online: International Labour Organization $<$ http://www.ilo.org/wcmsp5/groups/public/---asia/---ro-bangkok/documents/publication/wcms_317002.pdf>.

105 ILO: Employment, supra note 99 at 3; Gimenez et al, supra note 73 at 1.

${ }^{106}$ ILO: Employment, ibid; Gimenez et al, ibid at 71.

${ }^{107}$ BGMEA: Membership, supra note 79.

${ }^{108} \mathrm{Ibid}$; World Bank: Data, supra note 96.
} 


\section{vi. Bangladesh has the Ingredients Corporations Desire}

The Bangladesh Garment Manufacturers and Exporters Association, which represents the RMG industry, is determined to increase export earnings from RMG to $\$ 50$ billion in 2021, while the GOB concurrently seeks to escalate GDP growth to seven percent annually, relying heavily on RMG. ${ }^{109}$ Since Bangladesh offers a surplus of inexpensive labor, its appeal to manufacturers is unrivaled, as the latter is driven by profit maximization (Friedman doctrine), and the country offers the necessary ingredient to that end (inexpensive labor). This has permitted Bangladesh to truly specialize in global garment production.

\section{D - WILL GLOBALIZATION PERSIST?}

In the preceding sections, I have explained the intellectual basis for international trade and its results, which was the reduction of barriers to trade post the conclusion of the Second World War, marked by the establishment of the IMF, World Bank, and the GATT. The conversation on Bangladesh has illustrated why LCL, motivated by profit maximization, was having garments fabricated in the said country. In this section, I will briefly answer whether globalization will persist, for if it does, I will explain what the implications of my research are.

As globalization has virtually eliminated national boundaries, some scholars argue that this marks the end of the nation-state. ${ }^{110}$ Currently, governments do not retain the same authority over economies and society they once did. ${ }^{111}$ As Susan Strange declares, "Where [S]tates were once the masters of markets, now it is the markets which, on many crucial issues, are the masters

\footnotetext{
109 “Export Target of US \$50 Billion by 2021 set by Bangladesh RMG Sector" Apparel Resources (9 September 2015), online: Apparel Resources: Everything Sourcing < http://news.apparelresources.com/trade-news/exporttarget-of-us-50-billion-by-2021-set-by-bangladesh-rmg-sector/>; ILO: Employment, supra note 99 at 3.

${ }^{110}$ Marks \& Clapham, supra note 50 at 182.

${ }^{111}$ Lechner \& Boli, supra note 50 at 232.
} 
over the governments of states." 112 Nonetheless, others believe that globalization does not curtail State authority, and therefore, the view that a State's power has declined is mythical. ${ }^{113}$ As in, the State is not disappearing, but is perhaps "disaggregating"; and these smaller components are becoming the primary actors that are interacting with foreign bodies across borders. ${ }^{114}$ Therefore, States will remain the most powerful actors in global affairs, regardless of the sizes of MNEs, and this fact is immune to any potential changes. ${ }^{115}$

Additionally, there are those who believe that globalization accentuates inequalities. ${ }^{116}$ As in, developed countries quickly attain benefits, while developing countries are slow to see improvements. Others say, “[I]t leaves some people behind, but it helps millions” increase economic prosperity. ${ }^{117}$ Whereas supporters of globalization believe that it is leading to greater global cohesion, skeptics argue the contrary. ${ }^{118}$ Regardless, of the opinion held in academia, there is consensus among scholars that globalization is vital to the economic prosperity of a nation. ${ }^{119}$ The countries of East Asia have developed and have alleviated poverty by adopting globalization and capitalizing on exports, as has Bangladesh with its RMG industry. ${ }^{120}$

112 Ibid at 233 .

113 Marks \& Clapham, supra note 50 at 182; See generally Linda Weiss, The Myth of the Powerless State (Ithaca, NY: Cornell University Press, 1998).

114 Anne-Marie Slaughter, A New World Order (Princeton, NJ: Princeton University Press, 2004) at 18.

115 Samuel Huntington, “The Clash of Civilizations?” (1993) 72 Council on Foreign Relations 22 at 22.

${ }^{116}$ Marks \& Clapham, supra note 50 at 184; See generally David Held \& Anthony McGrew, Globalization/AntiGlobalization (Malden, MA: Blackwell Publishers, 2002).

${ }^{117}$ Lechner \& Boli, supra note 50 at 13.

118 Cees Hamelink, “The Elusive Concept of Globalisation” (1999) 1 Global Dialogue 1 at 2.

119 Stiglitz, supra note 10 at 4.

120 Joseph Stiglitz, “Globalism’s Discontents” The American Prospect (4 January 2002), online: The American Prospect $<$ http://prospect.org/article/globalisms-discontents $>$. 
Based on my above research, I side with those in favor of globalization, as it otherwise would have taken Bangladesh longer than 44 years to alleviate poverty by $40 \%$. That is, if not for its RMG industry, what would the country's economy currently look like? Though Bangladesh is experiencing slow growth, it is positive growth nonetheless. Therefore, it is my belief, premised on research, that globalization helps countries develop, even if economic prosperity is slow. As I illustrate in the next Chapter, regardless of how much wealth MNEs accumulate because of globalization, the power of the State will not diminish.

Since 2000, growth of international trade has averaged 2\%. ${ }^{121}$ In 1948, while world export of goods amounted to $\$ 58$ billion, the number escalated to $\$ 18$ trillion in 2014 , representing an exponential leap of $31,034 \%{ }^{122}$ In 1995 , world merchandise exports totaled $\$ 5.1$ trillion, leaping to $\$ 10.05$ trillion in 2005 , and $\$ 18$ trillion in $2014 .{ }^{123}$ Therefore, it would be incorrect to proclaim that globalization will diminish. Premised on empirical evidence, globalization will only continue with the passage of time, and its key actors - MNEs - will further accumulate capital and power. ${ }^{124}$

\section{E - RESEARCH IMPLICATIONS}

While this research underscores the benefits of globalization, particularly on Bangladesh and its RMG industry, it also draws attention to the accruing power of MNEs. Facilitated by neoliberalism, and globalization's ability to reduce costs in transportation, the visage of modern

\footnotetext{
121 "International Trade Statistics 2007” World Trade Organization (2007), online: World Trade Organization $<$ https://www.wto.org/english/res_e/statis_e/its2007_e/its2007_e.pdf $>$ at 1 .

122 Bossche, supra note 8 at 7. "International Trade Statistics 2015" World Trade Organization (2015), online: World Trade Organization < https://www.wto.org/english/res_e/statis_e/its2015_e/its15_highlights_e.pdf $>$ at 10 [WTO: ITS 2015]. General URL < https://www.wto.org/english/res_e/statis_e/its2015_e/its $1 \overline{5}$ toc_e.htm $>$.

123 WTO: ITS 2015, ibid at 14.

124 Shaker Zahra, "The Changing Rules of Global Competitiveness in the 21st Century" (1999) 13 Academy of Management 36 at 36.
} 
business has forever changed. Friedman's declaration that a corporation should only pursue profits has led some to proclaim that it is a "pathological institution," which is a "dangerous possessor of the great power it wields over people and societies." ${ }^{\text {"25 }}$ Due to reduced barriers to trade, outsourcing, and subsidiarization, it is unsurprising that numerous MNEs attain greater revenues than the GDP of many countries. ${ }^{126}$

Between 1946 and 1969, foreign direct investment (hereinafter "FDI") from the United States, predominantly led by MNEs, rose from $\$ 7.2$ billion to $\$ 70.7$ billion. ${ }^{127}$ In 2003 , Coca Cola's profits from the first six months of operations was more than the GDP of Gambia, Liberia, Eritrea, and Djibouti. ${ }^{128}$ In the early 1970s, the total revenue of the eight largest MNEs was identical to the global budget expenses of Belgium, Germany, France, Italy, Luxembourg, and Netherlands combined. ${ }^{129}$ Contemporary research suggests that the fifteen largest MNEs now procure revenue greater than all but thirteen States. ${ }^{130}$ Perhaps the most remarkable statistic is that of the hundred largest concentrations of wealth, $51 \%$ is owned by MNEs and the remaining $49 \%$ is owned by States. ${ }^{131}$

\footnotetext{
${ }^{125}$ Joel Bakan, The Corporation: The Pathological Pursuit of Profit and Power (Toronto: Penguin Canada, 2004) at 2.

${ }^{126}$ Muchlinski, supra note 9 at 3.

${ }^{127}$ Christopher Tugendhat, The Multinationals (London: Eyre and Spottiswoode, 1971) at 45; The magnum opus to consult is the work of Raymon Vernon, Sovereignty at Bay: The Multinational Spread of U.S. Enterprises (New York: Basic Books, 1971).

${ }^{128}$ Ilias Bantekas, “Corporate Social Responsibility in International Law” (2004) 22 BU Int'l LJ 309 at 309

[Bantekas].

129 José Antunes, “The Liability of Polycorporate Enterprises” (1998-1999) 13 Conn J Int'1 L 197 at 203 [Antunes].

${ }^{130}$ Carlos Vázquez, "Direct vs. Indirect Obligations of Corporations Under International Law” (2004-2005) 43 Colum J Transnat'l L 927 at 948; Muchlinski, supra note 9 at 3.

${ }^{131}$ Nicola Jäggers, Human Rights Standards and The Responsibility of Transnational Corporations, ed by Michael Addo (Cambridge, MA: Kluwer Law International, 1999) at 260 [Addo].
} 
What can be seen from the above discussion is that economic activity of modern societies is dominated by MNEs. Therefore, MNEs have been described as the most powerful agent for the "internationalization of human society."132 The activities of MNEs create employment opportunities for the country where the MNE operates, and benefits both the MNE and the country. However, it may be improbable to maintain a healthy and democratic society when so much political and economic power is concentrated in a modicum of corporations. ${ }^{133}$ As in, while it can be accepted that MNEs bring about vital economic development, they are equally capable of inflicting detrimental harms upon society. ${ }^{134}$

This concern is not without merit. There exists documented proof of the abuse of power by MNEs, most notably in the ousting of the elected President of Chile, Salvador Allende, in 1973, by the International Telephone and Telegraph Company. ${ }^{135}$ Even in 1954, the United Fruit Company, an American MNE, orchestrated a coup d'etat in Guatemala because it feared that the country's land reform policies could lead to expropriation of its property. ${ }^{136}$ The operations of

\footnotetext{
${ }^{132}$ Henry Hansmann, Reinier Kraakman \& Richard Squire, "Law and the Rise of the Firm" (2006) 119 Harv L Rev 1333 at 1336; Fleur Johns, "The Invisibility of the Transnational Corporation: An Analysis of International Law and Legal Theory" (1993-1994) 19 Melb U L Rev 893 at 893 [Johns].

${ }^{133}$ David Kinley \& Junko Tadaki, "From Talk to Walk: The Emergence of Human Rights Responsibilities for Corporations at International Law" (2003-2004) 44 Va J Int'l L 931 at 933 [Kinley \& Tadaki]; Also see Eric Kolodner, "Transnational Corporations: Impediments or Catalysts of Social Development" United Nations Research Institute for Social Development (November 1994), online: United Nations <http://www.unrisd.org/ 80256B3C005BCCF9/(httpAuxPages)/BFDE1D6D1B24C8FD80256B65004B6D57/\$file/OPWSSD5.pdf > at 4-7; David Korten, When Corporations Rule the World, 2d ed (San Francisco: Berrett-Koehler Publishers, 2001) at 181.

${ }^{134}$ Beth Stephens, “Corporate Liability: Enforcing Human Rights Through Domestic Litigation” (2000-2001) 24 Hastings Int'l \& Comp L Rev 401 at 401.

135 Theodore Moran, Multinational Corporations and the Politics of Dependence: Copper in Chile (Princeton, NJ: Princeton University Press, 1974) at 252-253; It was said the Allende threatened to nationalize ITT's $60 \%$ share in Chile's national phone company, at Theodore Moran, "The United Nations and Transnational Corporations: A Review and a Perspective" United Nations Conference on Trade and Development (2009), online: UNCTAD <http:// unctad.org/en/Docs/diaeiia200910a4_en.pdf> at 92.

${ }^{136}$ Ariadne Sacharoff, "Multinationals in Host Countries: Can They be Held Liable Under the Alien Tort Claims Act for Human Rights Violations?” (1997-1998) 23 Brook J Int'l L 927 at 927.
} 
MNEs have attracted global attention, with the spectrum of scrutinized activities, overthrow of Allende excepted, being horrid working conditions, environmental degradation, and complicity in human rights violations. ${ }^{137}$

Stemming from my exposition of globalization, since it is clear that this phenomenon will not diminish, for the purposes of global governance, how can MNEs be regulated amid neoliberal policies, when States generally disfavor market intervention? Since global economic integration is irreversible, or is reversible only at the cost of bringing about irreparable economic damage, is there a solution to prohibit the recurrence of another Rana Plaza? More importantly, in the absence of a global government, combined with the fact that international law does not hold MNEs accountable for misconduct, what avenue exists for victims harmed by MNEs to seek redress? John Ruggie has said that reforming MNE liability is an "urgent policy priority."138 This reform should bring corporations into a legal order on the principle of accountability, which is "the requirement to explain and accept responsibility for one's actions." ${ }^{139}$ Since globalization has created interdependence, some form of transboundary stability should emerge, similar to the global economic stability that was produced after the conclusion of the Second World War with the inception of the IMF, World Bank, and the GATT.

\footnotetext{
${ }^{137}$ Allison Snyder, "Holding Multinational Corporations Accountable: Is Non-Financial Disclosure the Answer?” (2007) 2007 Colum Bus L Rev 565 at 566; Also see Christina Baez et al, "Multinational Enterprises and Human Rights" (1999-2000) 8 U Miami Int'l \& Comp L Rev 183 at 244-246.

138 John Ruggie, Promotion and Protection of all Human Rights, Civil, Political, Economic, Social and Cultural Rights, Including the Right to Development, UNHRCOR, 8th Sess, UN Doc A/HRC/8/5, (2008) 1 at 9.

${ }^{139}$ Christopher Weeramantry, "Human Rights and the Global Marketplace” (1999) 25 Brook J Int'l L 27 at 49 ; "Canadian Democracy \& Corporate Accountability: An Overview of Issues" The Democracy and Corporate Accountability Commission (2001), online: Canadian Democracy \& Corporate Accountability $<$ http:// aix1.uottawa.ca/ cforcese/other/commissionpaper.pdf $>$ at 2; International Council on Human Rights Policy, Beyond Voluntarism: Human Rights and the Developing International Legal Obligations of Companies (Versoix, CH: International Council on Human Rights Policy, 2002) at $157<\mathrm{http}$ //www.ichrp.org/files/reports/ 7/107_report_en.pdf>.
} 


\section{III - WHY INTERNATIONAL LAW DOES NOT SUFFICE}

In this Chapter, first, I will explore critical arguments of holding MNEs accountable for misconduct, particularly international law and its often-employed instruments in regulation. I will demonstrate international law's inability to address challenges posed by the operations of modern MNEs. In the event of a disaster resulting from their activities, MNEs adopt voluntary codes forthwith to confront the specific issue. This also ensures to the public that the corporation is not irresponsible and that it cares about the environment where it operates. However, international law and voluntary codes are grossly inefficient in the case of Rana Plaza, as I will reveal below, international law only applies to States and voluntary codes lack sanctioning abilities. It is then that I arrive at the heart of the issue in seeking to determine whether liability can be imposed on LCL. For the purposes of global governance, I import the theory of enterprise liability, after exploring the anachronistic nature of entity law, and demonstrate that it is better suited to the nature of modern multinational enterprises.

Before moving forward, I would like to introduce three questions. By engaging with these queries, I will be able to provide a comprehensive description of the gap created by the lack of MNE regulation. First, if MNEs are operating in multiple jurisdictions, what role does international law play in ensuring that MNEs do not violate the lex terrae in which they operate? Next, if MNEs are adopting voluntary codes to ensure environmental sustainability, to what extent are they effective? Third, if the subsidiary operates as a distinct legal entity, which essentially shields the parent company from liability arising from the former's misconduct, can the latter nonetheless be held liable for the subsidiary's wrongdoing? 


\section{A - DOMESTIC LAW, INTERNATIONAL LAW \& THE REGULATION OF MULTINATIONAL ENTERPRISES}

In the domestic forum, corporations are artificial persons that have been granted legal personality in the locus classicus House of Lords decision, Salomon v Salomon \& Co Ltd. ${ }^{1}$ Legal personality, which is the "capacity for legal relations," is when legal rights are granted, permitting corporations to buy and sell property, engage in tortious conduct, enter into contracts, and sue and be sued, despite a corporation's persona ficta status. $^{2}$ Legal personality is precisely what transforms the corporation into a person carrying "rights and duties." 3 Therefore, a corporation's domestic misconduct allows a court to impose liability on it. That is, if a corporation is found to be in breach of domestically enacted statutes, or their conduct is found negligent, ${ }^{4}$ the aggrieved party, whether a sentient being or another artificial person, can formally seek redress. In the context of MNEs, this poses a problem because they are operating in multiple jurisdictions. Subsequently, the question that must be asked is whether MNEs have international legal personality, for if they do, international law will regulate their conduct. However, corporations do not have international legal personality. ${ }^{5}$

The two general divisions of international law are public international law (more commonly referred to, and what I will consistently mention as, "international law") and private

\footnotetext{
${ }^{1}$ Salomon v Salomon \& Co Ltd, [1897] AC 22, 66 LJ Ch 35 [Salomon]; It is unknown that the concept of legal personality was discussed in 1444, in the Rolls of Parliament, where it was said, "[T] hey [the Master and Brethren of the Hospital] by that same name mowe be persones able to purchase Londez and Tenementz of all manere persones," at Sanford Schane, "The Corporation is a Person: The Language of a Legal Fiction" (1986-1987) 61 Tul L Rev 563 at 563.

${ }^{2}$ Bryant Smith, "Legal Personality” (1928) 37 Yale LJ 283 at 283.

${ }^{3}$ Ibid.

${ }^{4}$ For a detailed account on negligence, see Allen Linden \& Bruce Feldthusen, Canadian Tort Law: Student Edition, 9th ed (Markham: LexisNexis Canada Inc, 2011) at 113-200, which I will cover in Chapter 4.

${ }^{5}$ Ilias Bantekas, “Corporate Social Responsibility in International Law” (2004) 22 BU Int'1 LJ 309 at 312 [Bantekas].
} 
international law. ${ }^{6}$ Public international law is the legal system that is concerned with international rule-making, and thus, would purportedly regulate MNEs. ${ }^{7}$ However, as Rosalyn Higgins declares, States are "at the heart of the international legal system," and therefore, international law does not view MNEs as its subjects. ${ }^{8}$ As in, international law is formulated by States working harmoniously and governs the relationship between States because it views them to be its central actors. ${ }^{9}$ This 'State-centric' approach of international law has led some to doubt whether it can address the challenges MNEs currently pose. ${ }^{10}$ Since MNEs are not traditional subjects of international law, numerous commentators have said that their activities cannot be sufficiently regulated by international law. ${ }^{11}$

Simply stated, if a person is unrecognized by corpus juris as subjects, then the law will not apply to him. Therefore, international law does not directly regulate the conduct of MNEs as the latter is considered its objects. Since MNEs are viewed as objects of international law, they

\footnotetext{
${ }^{6}$ Jennifer Zerk, Multinationals and Corporate Social Responsibility: Limitations and Opportunities in International Law (Cambridge, UK: Cambridge University Press, 2006) at 61 [Zerk]; Private international law is the branch of domestic law governing how national courts ought to approach a complaint carrying a foreign element, specifically whether it is appropriate and convenient - forum non conveniens - that the court accepts jurisdiction of a complaint. However, the question of whether to accept jurisdiction is discretionary and variegated between nations, and in Canada, is imported only after a determination is made that the court sought retains jurisdiction, at $C l u b$ Resorts Ltd v Van Breda, [2012] 1 SCR 572 at paras $98 \& 101$. Therefore, I will not engage in a further discussion of private international law as it is prima facie unconcerned with the regulation of MNE conduct. Its primary purpose is to adjudicate on disputes only after an issue arises, and it, therefore, only regulates the behavior of the aggressor thereafter, as it does not principally make rules, but interprets them.

${ }^{7}$ Zerk, ibid at 62.

${ }^{8}$ Rosalyn Higgins, Problems and Process: International Law and How We Use it (New York: Oxford University Press, 1994) at 39-40; Also see Anne-Marie Slaughter, "International Law and International Relations Theory: A Dual Agenda" (1993) 87 Am J Int'l L 205 at 227.

${ }^{9}$ Sir Arthur Watts, The Role of Law in International Politics: Essays in International Relations and International Law, ed by Michael Byers (New York: Oxford University Press, 2000) at 5 [Byers].

${ }^{10}$ Detlev Vagts, “The Multinational Enterprise: A New Challenge for Transnational Law” (1970) 83 Harvard L Rev 739 at $756-763$.

${ }^{11}$ Fleur Johns, "The Invisibility of the Transnational Corporation: An Analysis of International Law and Legal Theory" (1993-1994) 19 Melb U L Rev 893 [Johns]; Bantekas, supra note 5 at 310-311; David Kinley \& Junko Tadaki, "From Talk to Walk: The Emergence of Human Rights Responsibilities for Corporations at International Law” (2003-2004) 44 Va J Int'l L 931 at 937-939; Anne-Marie Slaughter in Byers, supra note 9 at 181-186.
} 
are said to lack international legal personality. Therefore, since MNEs lack international legal personality, international law does not regulate their behavior.

\section{B - HARD LAW \& SOFT LAW}

According to Philip Allott, the most visible signs of international law are treaties formulated by States. ${ }^{12}$ Article 38(1) of the Statute of the International Court of Justice (hereinafter " $I C J^{\prime}$ ') is commonly held as the most authoritative description of the sources of international law. ${ }^{13}$ In hierarchical order, the sources are convention, custom, general principles of international law, and judicial decisions and publications of qualified persons. Courts turn to whether the State's impugned conduct was inconsistent with one of the enumerations. If it is found that the State breached an Article 38(1) stipulation, a court can order the State to correct its behavior. Therefore, these authorities seek to directly regulate the conduct of States - not MNEs. Since treaties and custom regulate State behavior, they are considered hard law on the grounds that an affected party can seek remedy for a State's incorrect behavior. ${ }^{14}$ Nonetheless, I draw attention to the fact that treaties and custom do not apply to MNEs, as they are concerned with regulating the conduct of States.

As I have shown that international law, particularly hard law, does not regulate the conduct of MNEs, this brings into discussion whether soft law has any instruments for this

\footnotetext{
12 Byers, supra note 9 at 80-81.

${ }^{13}$ Bhupinder Chimni, “An Outline of a Marxist Course on Public International Law” (2004) 17 Leiden J Int'l L 1 at 11; Hilary Charlesworth, Christine Chinkin \& Shelley Wright, "Feminist Approaches to International Law" (1991) 85 Am J Int'l L 613 at 632-634; Zerk, supra note 6 at 63.

${ }^{14}$ Alan Boyle \& Christine Chinkin, The Making of International Law (New York: Oxford University Press, 2007) at 19-20 [Boyle \& Chinkin]; Jane Hong, "Enforcement of Corporate Codes of Conduct: Finding a Private Right of Action for International Laborers Against MNCs for Labor Rights Violation” (2000-2001) 19 Wis Int'l LJ 41 at 60 [Hong]
} 
purpose. Soft law refers to principles and policies negotiated between States. ${ }^{15}$ However, the crucial difference between soft law and hard law is that compliance with the former is voluntary, while it is a legal imperative to comply with hard law. Interestingly, while both soft law and hard law are binding, a weakness in soft law instruments is that it does not have the ability to sanction a State for misconduct. ${ }^{16}$ Therefore, since States will not be sanctioned, they have publicly said that they feel no obligation to comply with soft law instruments. According to Alan Boyle and Christine Chinkin, anything that is not stipulated in Article 38 of the ICJ is a form of soft law. ${ }^{17}$

The most influential instruments of soft law governing MNE conduct are the $O E C D$ Guidelines for Multinational Enterprises (hereinafter “OECD Guidelines”), ILO Tripartite Declaration on Principles Concerning Multinational Enterprises and Social Policy (hereinafter "ILO Tripartite Declaration"), UN Global Compact, and the UN Guiding Principles on Business and Human Rights (hereinafter "Guiding Principles"), which I will briefly discuss below. ${ }^{18}$ Prior to discussing the aforementioned, I will speak of the nine core international human rights instruments, which are held to indirectly regulate the conduct of MNEs.

\section{i. Core International Human Rights Instruments}

There are nine core international human rights instruments. ${ }^{19}$ Specifically, the International Covenant on Civil and Political Rights (hereinafter "ICCPR") and the

\footnotetext{
${ }^{15}$ Byers, supra note 9 at 83; Zerk, supra note 6 at 69-70; Generally, one can identify soft law as its names are restricted to the following: "codes of practice," "guidelines," "recommendations," and "declarations," at 70.

${ }^{16}$ Christine Chinkin, "The Challenge of Soft Law: Development and Change in International Law" (1989) 38 ICLQ 850 at 866 [Chinkin].

${ }^{17}$ Boyle \& Chinkin, supra note 14 at 211-216; Also see Chinkin, ibid.

${ }^{18}$ Bantekas, supra note 5 at 319.

19 "The Core International Human Rights Instruments and their Monitoring Bodies" United Nations Human Rights: Office of the High Commissioner (2016), online: UN OHCHR <http://www.ohchr.org/EN/ProfessionalInterest/ Pages/CoreInstruments.aspx $>$.
} 
International Covenant on Economic, Social and Cultural Rights (hereinafter "ICESCR")

contain provisions for fair wages, safe and healthy working conditions, reasonable limitations on

working hours, and freedom from discrimination. ${ }^{20}$ However, there are three caveats to these

instruments. First, the ICCPR and the ICESCR, in addition to the remaining seven instruments,

apply only to States and presumes States to be the primary violators of the rights contained

therein — not MNEs. ${ }^{21}$ Secondly, these instruments are binding only on UN Member States, and

therefore, do not apply to non-UN Members. ${ }^{22}$ And third, though the treaties are binding, they

are considered soft law because they lack sanctioning abilities. ${ }^{23}$

\section{i.1 - International Labour Organization}

In addition to the nine core international human rights instruments, the ILO, since its

inception in 1919, has enacted 189 Conventions that cover worker rights in order to bring global

labor standards and prevent deplorable working conditions. ${ }^{24}$ The predicament, again, is that the

ILO, while being the premier international organization addressing worker rights and serving as

\footnotetext{
${ }^{20}$ Sarah Cleveland, "Global Labor Rights and the Alien Tort Claims Act” (1997-1998) 76 Tex L Rev 1533 at 1540 [Cleveland]; For the ICCPR, see particularly Arts 7, 22(1), and 24(1); For the ICESCR, see particularly Arts 3, 7 , and 11(1); The other instruments are (1) International Convention on the Elimination of All Forms of Racial Discrimination; (2) Convention on the Elimination of All Forms of Discrimination against Women; (3) Convention against Torture and Other Cruel, Inhuman or Degrading Treatment or Punishment; (4) Convention on the Rights of the Child; (5) International Convention on the Protection of the Rights of All Migrant Workers and Members of Their Families; (6) International Convention for the Protection of All Persons from Enforced Disappearance; and (7) Convention on the Rights of Persons with Disabilities.

21 Johns, supra note 11 at 909.

22 For a list of UN Member States, see "Member States" United Nations (2016), online: UN <http://www.un.org/en/ member-states/>.

${ }^{23}$ Cleveland, supra note 20 at 1541; Also see Laura Ho, Catherine Powell \& Leti Volpp, “(Dis)assembling Rights of Women Workers Along the Global Assembly Line: Human Rights and the Garment Industry” (1996) 31 Harv CRCLL L Rev 383 at 396 [Ho et al]; Andrew Guzman \& Timothy Meyer, "International Common Law: The Soft Law of International Tribunals” (2009) 9 Chicago J Int'l L 515 at 518-519.

24 “Conventions" International Labour Organization (2012), online: ILO < http://www.ilo.org/dyn/normlex/en/f? p=1000:12000:751417052845782::::P12000_INSTRUMENT_SORT:4>; In fact, it was in 1890 that Kaiser Wilhelm convened the first international labor standards conference, at Cleveland, ibid at 1534.
} 
a specialized organ of the UN since 1947, does not have the ability to sanction a noncompliant Member. ${ }^{25}$ Therefore, when a State violates an ILO Convention, the ILO uses "moral persuasion, publicity, shame, diplomacy, and dialogue" in an attempt to bring about compliance. ${ }^{26}$ The ILO has used no form of sanctions heretofore, and its procedures are without sanctioning abilities, which is an indefensible weakness in the organization. ${ }^{27}$ Concerns of persistent violators of labor rights are endemic in the annual reports compiled by the Committee of Experts. ${ }^{28}$ Furthermore, similar to the ICCPR and the ICESCR, Conventions and Recommendations, which are nonbinding guidelines, of the ILO apply only to States, and they do not apply to MNEs. ${ }^{29}$

Based on the foregoing discussion, three qualifications become clear. First, and I remain doubtful whether I can emphasize on this further, international law does not regulate the conduct of MNEs. From its onset, it has been focused on governing relations between States, and therefore, has viewed States as its subjects. Second, there are certain conventions that, despite their binding authority, are considered soft law due to their inability to impose sanctions. Third, soft law instruments regulating labor rights and safety in the context of employment, apply only to States and not on MNEs. This has led a modicum of commentators to remark that a State could be held liable if found to be in violation of a convention because it failed to regulate the

\footnotetext{
25 Daniel Ehrenberg, “The Labor Link: Applying the International Trading System to Enforce Violations of Forced and Child Labor” (1995) 20 Yale J Int'l L 361 at 376-382 [Ehrenberg].

${ }^{26}$ Ibid at $388-389$.

27 Ibid at 389.

${ }^{28} \mathrm{Ibid}$; The Committee of Experts consists of twenty legal experts, who are appointed for three-year renewable terms by the Governing Body, are geographically balanced and serve the ILO in their personal capacity, at 384 . The Governing Body is the executive council of the ILO, responsible for, inter alia, the appointment of the Director General and overseeing activities of the International Labour Office, at 383.

${ }^{29}$ Ibid at 381-386; Ehrenberg has proposed that the ILO be consolidated with the WTO so that the former may retain sanctioning abilities through that which is already possessed by the latter; "Conventions and Recommendations" International Labour Organization (2016), online: ILO <http://www.ilo.org/global/standards/introduction-tointernational-labour-standards/conventions-and-recommendations/lang--en/index.htm>.
} 
conduct of MNEs headquartered within its territorial borders. ${ }^{30}$ As in, since some of the above discussed instruments apply to States, it is said that they impose a duty on States to regulate MNE behavior. I do not engage in this argument as my primary purpose is to determine whether LCL can be held liable for the deaths and injuries resulting from the collapse of Rana Plaza. Nonetheless, what is important to note is that whether soft law or hard law, international law is not concerned with regulating the behavior of MNEs.

\section{i.2 - OECD Guidelines for Multinational Enterprises}

The OECD Guidelines were originally promulgated in 1976 with a substantial revision in 2000, which places heavy emphasis on labor standards. ${ }^{31}$ However, the purpose of the $O E C D$ Guidelines was never to be binding; as in, non-compliance does not warrant sanctions. ${ }^{32}$ Rather, National Contact Points are established that encourage compliance with the OECD Guidelines. Additionally, the $O E C D$ Guidelines are applicable only to OECD countries, Canada being a signatory while Bangladesh is not. Furthermore, if another OECD country feels that their rights may have been impaired, there is a lack of clarity in the procedure of how the aggrieved party is to pursue action thereafter. ${ }^{33}$

\footnotetext{
${ }^{30}$ See Cleveland, supra note 20; Alison Gormley, “The Underground Exposed: The United States Corporations' Use of Sweatshops Abroad, and the Abuse of Women” (2001-2002) 25 Suffolk Transnat'l L Rev 109; Lena Ayoub, “Nike Just Does It - And Why the United States Shouldn't: The United States' International Obligation to Hold MNCs Accountable for their Labor Rights Violations Abroad" (1998-1999) 11 DePaul Bus LJ 395 [Ayoub]; Ho et al, supra note 23; Susana Peña, "Human Rights Violations by Canadian Companies Abroad: Choc v Hudbay Minerals Inc" (2014) 5 West J Legal Stud 3 [Peña].

31 Jill Murray, “A New Phase in the Regulation of Multinational Enterprises: The Role of the OECD” (2001) 30 Indus LJ 255 at 259.

32 Zerk, supra note 6 at 251.

${ }^{33}$ Ibid at 252-253; For a list of OECD Members, see "List of OECD Member Countries - Ratification of the Convention on the OECD” Organization for Economic Cooperation and Development (2016), online: OECD: Better Policies for Better Lives <http://www.oecd.org/about/membersandpartners/list-oecd-member-countries.htm>; Additionally, the National Contact Point of the United Kingdom does not disclose details of the complaints filed under the OECD Guidelines and its subsequent implementation procedure. Therefore, while there already exists confusion about how an aggrieved party is to proceed, the non-disclosure of complaints filed further obfuscates this understanding, at 254.
} 


\section{i.3 - ILO Tripartite Declaration}

The ILO Tripartite Declaration was adopted by the Governing Body of the ILO in 1977, with one amendment made in 1998 to incorporate the Declaration on Fundamental Principles and Rights at Work. ${ }^{34}$ The Declaration seeks to maintain international labor standards because the ILO saw that MNE operations brought horrible working conditions in developing countries. However, as I have previously stated, the ILO cannot sanction a Member even if the Member is in violation of an ILO Convention or Recommendation. ${ }^{35}$

\section{i.4 - UN Global Compact}

The UN Global Compact, launched in 1999 by then Secretary General Kofi Annan, facilitates dialogue between MNEs and the UN about issues arising from globalization. ${ }^{36}$ Ten principles related to, inter alia, human rights and labor, are stipulated that apply to UN Member States. However, the UN Global Compact is not binding and only serves as a framework within which MNEs should operate. Additionally, there is no external monitoring. ${ }^{37}$ As in, no organization has the authority to oversee whether MNEs are operating within its framework.

\section{i.5 - UN Guiding Principles on Business and Human Rights}

In the early 1970s, in response to ITT's involvement in the overthrow of Salvador Allende, the Group of 77, which is an organization of developing countries, led the UN to formulate the Code of Conduct for Transnational Corporations, but it was never formally

\footnotetext{
${ }^{34}$ Zerk, ibid at 254-255; For an excellent overview of the three principal bodies of the ILO, see Ehrenberg, supra note 25 at $382-388$.

${ }^{35}$ Lance Compa \& Tashia Hinchcliffe-Darricarrère, "Enforcing International Labor Rights through Corporate Codes of Conduct" (1995) 33 Colum J Transnat'l L 663 at 671 [Compa \& Darricarrère].

${ }^{36}$ Zerk, supra note 6 at 258; The UN Global Compact speaks of a principled business that should support the society around them, and engage in positive behavior where they operate.

${ }^{37}$ Ibid at 259.
} 
adopted. ${ }^{38}$ Its objective was to ensure MNEs respect human rights and treat workers fairly. While it was permanently shelved, the United Nations Human Rights Council endorsed the Guiding Principles in 2011, which was developed by John Ruggie. The Guiding Principles have been touted as the "authoritative global standard on business and human rights." 39 The three foundational pillars of the Guiding Principles are State's duty to protect against human rights abuses; business enterprises' duty to respect human rights; and access to remedy for those affected. ${ }^{40}$ However, the greatest disadvantage of the UN Guiding Principles is that it is a form of soft law; therefore, it has no sanctioning abilities. ${ }^{41}$

In summation, soft law instruments relating to MNEs are voluntary and no organization exists to ensure compliance. Additionally, it was never the objective of the OECD Guidelines and the UN Global Compact to be binding; rather, they facilitate dialogue between States and MNEs. Though the ILO Tripartite Declaration seeks to maintain global labor standards, and the Guiding Principles outline human rights standards, they cannot sanction States. Therefore, in the absence of a world government, who really governs the conduct of MNEs or ensures that victims harmed by MNEs can seek redress? In the event of a disaster causing injuries, MNEs willingly engage in CSR initiatives. That is, they want to seem socially responsible in order to avoid negative

\footnotetext{
${ }^{38}$ Compa \& Darricarrère, supra note 35 at 669-670; See pages 47-48, supra at Chapter 2.

${ }^{39}$ Report of the Working Group on the Issue of Human Rights and Transnational Corporations and other Business Enterprises, UNHRCOR, 20th Sess, UN Doc A/HRC/20/29, (2012) at paras 4 \& 10; For the Guiding Principles, see "Guiding Principles on Business and Human Rights" United Nations Human Rights Office of the High Commissioner (2011), online: OHCHR < http://www.ohchr.org/Documents/Publications/ GuidingPrinciplesBusinessHR_EN.pdf $>$.

${ }^{40}$ Report of the Special Representative of the Secretary-General on the Issue of Human Rights and Transnational Corporations and other Business Enterprises, John Ruggie, Guiding Principles in Business and Human Rights: Implementing the United Nations "Protect, Respect and Remedy" Framework, UNHRCOR, 17th Sess, UN Doc A/ $\mathrm{HRC} / 17 / 31,(2011)$ at para 6; See generally Articles 1, 2, 12, 13, \& 25.

${ }^{41}$ Peña, supra note 30 at 2-3; Also see Ariane Lafarrière, After Rana Plaza: Women's Labour Rights in the Bangladesh Garment Export Industry (LL.M. Thesis, McGill University Faculty of Law, 2015) at 42-44 [unpublished].
} 
publicity. As I will demonstrate below, a negative image reduces a corporation's ability to profit from its operations.

\section{ii. Corporate Social Responsibility}

Corporate social responsibility is the range of activities that is economic, social, environmentally sustainable, and voluntarily undertaken by companies. ${ }^{42}$ In 1929 , Walter Donham said,

Businesses started long centuries before the dawn of history, but business as we now know it is new - new in its broadening scope, new in its social significance.

Business has not learned how to handle these changes, nor does it recognize the magnitude of its responsibilities for the future of civilization. ${ }^{43}$

The debate over CSR and the inherent responsibilities of business began in $1953 .{ }^{44}$ Then, Keith Davis suggested that if a corporation avoids social responsibility, its economic power in society will gradually erode. ${ }^{45}$ That is, the image of a corporation held by the public is directly related to the company's ability to profit from its business. ${ }^{46}$ To simplify, a positive image helps the

\footnotetext{
42 "Corporate Social Responsibility" Global Affairs Canada (2016), online: Government of Canada: Global Affairs Canada <http://www.international.gc.ca/trade-agreements-accords-commerciaux/topics-domaines/other-autre/csrrse.aspx?lang=eng\#CSR $>$; For an excellent history on the rise of CSR, its academic interest, and the plethora of definitions of 'CSR' propounded, see Archie Carroll, "Corporate Social Responsibility: Evolution of a Definitional Construct” (1999) 38 Bus \& Society 268 [Carroll].

${ }^{43}$ Zerk, supra note 6 at 15; Walter Donham was the Dean of Harvard Business School at the time of quotation.

${ }^{44}$ What is interesting to note is that CSR garnered academic interest through the works of Chester Bernard and John Clark in the 1930s before becoming truly topical in the 1950s, see Chester Bernard, The Functions of the Executive (Cambridge, Harvard University Press, 1938) and John Clark, Social Control of Business, 2d ed (New York: McGraw Hill, 1939); At this time, 'CSR' was known as 'social responsibility,' and Howard Bowen defined it as "[T] he obligations of businessmen to pursue those policies, to make those decisions, or to follow those lines of action which are desirable in terms of the objectives and values of our society," at 6; Also see Carroll, supra note 42 at 269-270.

${ }^{45}$ Keith Davis, “Can Business Afford to Ignore Social Responsibilities?” (1960) 2 Cal Management Rev 70 at 73; See Howard Owen, Social Responsibilities of the Businessman (New York: Harper, 1953).

${ }^{46}$ Michael Hopkins, The Planetary Bargain: Corporate Social Responsibility Matters (Sterling, VA: Earthscan Publications, 2003) at 14-17
} 
company profit, whereas a negative image does not. For example, on 3 December 1984 in Bhopal, India, methyl isocyanate gas from Union Carbide India Limited leaked into the atmosphere, instantly killing 3,000 people. ${ }^{47}$ This resulted in UCC losing \$581 million in 1985 because of its tarnished reputation, and to address this issue, it voluntarily adopted a code of conduct to reconstruct its image, which I will discuss below. ${ }^{48}$

While UCC succeeded in repairing its reputation and sustaining its business, Enron Corporation, an American energy company with a market capitalization of $\$ 60$ billion in 2000 , was not successful and filed for bankruptcy. ${ }^{49}$ Furthermore, James Hamilton has found that consumers remain abreast environmental issues, and companies that emitted significantly high toxins lost $\$ 4.1$ million annually, because consumers did not approve of this behavior. ${ }^{50}$ Therefore, since companies are concerned about their reputation, they remain cautious and voluntarily conduct themselves in a socially responsible manner. ${ }^{51}$ If a company has harmed society and has remained insouciant of its misconduct, there is a high probability that it will lose money in the subsequent fiscal year, which is against the interests of the profit-driven corporation. Even after the conclusion of the First World War, corporations from the United States, inter alia, General Electric, Eastman Kodak, Standard Oil, and the Goodyear Tire \&

\footnotetext{
${ }^{47}$ Kernaghan Webb, Law, Regulation, and Governance, ed by Michael MacNeil, Neil Sargent \& Peter Swan (Toronto: Oxford University Press, 2002) at 245 [Webb]; Richard Clayton Trotter, Susan Day \& Amy Love, "Bhopal, India and Union Carbide: The Second Tragedy" (1989) 8 J Bus Ethics 439-440 [Trotter et al].

48 Trotter et al, ibid at 446; I will discuss UCC's code of conduct below.

49 Paul Healy \& Krishna Palepu, "The Fall of Enron” (2003) 17 J Econ Perspectives 3 at 3; Fortune magazine declared that Enron was the "most innovative" large company in the United States, at 3.

50 Pratima Bansal \& Iain Clelland, "Talking Trash: Legitimacy, Impression Management, and Unsystematic Risk in the Context of the Natural Environment” (2044) 47 Academy of Management J 93 at 93-94.

${ }^{51}$ Peter Muchlinski, “Human Rights and Multinationals: Is there a Problem?” (2001) 77 Royal Institute Int'l Affairs 31 at 45 .
} 
Rubber Company, crafted a socially responsible image..$^{52}$ Therefore, MNEs realize that they can govern their conduct because no other institution exists for that purpose..$^{53} \mathrm{~A}$ popular technique used by MNEs is adopting voluntary codes following a disaster.

\section{iii. Voluntary Codes}

Voluntary codes influence, control, and shape behavior in a particular industry, encouraging companies to conduct themselves so that both the company and the community benefits. ${ }^{54}$ It signals to society that the organization's products and methods of production meet certain standards. With the growth of international business, and since international law does not regulate the conduct of MNEs, voluntary codes have multiplied in an attempt to fill the gap created by this lack of regulation. ${ }^{55}$ Companies such as, Levi Strauss \& Co., Phillips VanHeusen, Walmart, J.C. Penney, Reebok, Gap, Liz Claiborne, Ikea, Pottery Barn, Nike, LCL, Walmart, Canadian Tire, Timberland, British Airways, and NatWest have adopted such codes..$^{56}$

\section{iii.1 - A Modicum of Principles}

The Sullivan Principles, led by American companies, encouraged bias-free employment practices in South Africa. ${ }^{57}$ The objective of the MacBride Principles, which was directed

\footnotetext{
52 Joel Bakan, The Corporation: The Pathological Pursuit of Profit and Power (Toronto: Penguin Canada, 2004) at 18.

${ }^{53}$ Bhagwan Chowdhury \& Jonathan Howe, "Corporate Risk Management for Multinational Corporations: Financial and Operational Hedging Policies" (1999) 2 European Financial Review 229 at 230-231.

54 "Voluntary Codes Guide - What is a Voluntary Code?" Office of Consumer Affairs (9 March 2010), online: Government of Canada: Innovation, Science and Economic Development Canada <http://www.ic.gc.ca/eic/site/ocabc.nsf/eng/ca00963.html>.

${ }^{55}$ Compa \& Darricarrère, supra note 35 at 665.

${ }^{56}$ Ho et al, supra note 23 at 401; Ayoub, supra note 30 at 404-405; Cleveland, supra note 20 at 1552-1554; Simon Webley, Human Rights Standards and the Responsibility of Transnational Corporations, ed by Michael Addo (Cambridge, MA: Kluwer Law International, 1999) at 108 [Addo]; The list of companies is not exhaustive.

${ }^{57}$ Compa \& Darricarrère, supra note 35 at 666.
} 
towards American MNEs and was issued by the Irish Statesman, Sean MacBride, was to eliminate discriminatory employment practices in Northern Ireland. The Slepak Principles, led by the Soviet Union, and the Miller Principles, led by the United States, wanted to stop forced labor. The Maquiladora Code, led by the American Federation of Labor and Congress for Industrial Relations, promoted a safe and healthy workplace. The Rugmark Campaign, driven by the American based Child Labor Coalition, sought to abolish the use of child labor in the fabrication of carpets. ${ }^{58}$

Perhaps a more notable voluntary code is Responsible Care, which was initiated by the Canadian Chemical Producers' Association after a series of chemical disasters — Love Canal, Seveso, and most prominently, Bhopal. ${ }^{59}$ Responsible Care wanted to improve environmental safety standards and facilitate relations between the government and the chemical industry. By improving environmental safety, it would be able to garner public trust in the chemical industry. Therefore, by showing that signatory companies are being socially responsible of environmental safety, their trust in the chemical industry would resurge. ${ }^{60}$

\section{iii.2 - The Voluntary Response to Rana Plaza}

In the case of Rana Plaza, the Accord and Alliance are both voluntary initiatives undertaken by manufacturers to help improve working conditions in Bangladesh by inspecting supplier factories. ${ }^{61}$ While this may be commendable, the codes do not have an independent

\footnotetext{
58 Ibid at 671-673.

${ }^{59}$ Webb, supra note 47 at 245; See note 47 above for more details; Love Canal is a neighborhood in New York; Seveso is in the Lombardy region of Italy.

60 Webb, ibid.

61 "About the Accord" Accord on Fire and Building Safety in Bangladesh (2015), online: Accord <http:// bangladeshaccord.org/about/>; "Standards and Inspections" Alliance for Bangladesh Worker Safety (2015), online: Alliance $<$ http://www.bangladeshworkersafety.org/en/what-we-do/standards-inspections $>$.
} 
authority enforcing them. ${ }^{62}$ Additionally, it is not uncommon, as evinced by the Accord and the Alliance, for voluntary codes to generally not have an external organ to monitor compliance. Therefore, similar to soft law instruments that regulate MNE conduct, the word 'voluntary' illuminates the nature of such codes. As in, companies voluntarily adopt these codes to prevent negative publicity so that its reputation is not adversely affected. Therefore, it seems that voluntary codes are adopted for that purpose only and not to really improve conditions. Additionally, adopting voluntary codes is independent of liability and the unenforceable nature of these instruments militates against their efficacy. ${ }^{63}$

As international law and voluntary initiatives fail to regulate the conduct of MNEs, and since MNEs have proliferated because of globalization, in order to maintain transboundary stability, how can victims seek redress when harmed by MNEs? Moreover, CSR initiatives are undertaken to prevent the company from suffering financial loss, as opposed to serving as means of accountability. For example, apart from the above cited voluntary codes, MNEs operating in Africa have appeased angry locals by establishing public amenities so that the MNE can continue operations. ${ }^{64}$ As in, businesses contain social costs and these costs must occasionally be met for that business to continue. The fulfillment of these costs, however, is entirely independent of legal obligations. Moreover, corporate social responsibility relates to questions of ethics, which falls under the "realm of discretion." 65

\footnotetext{
${ }^{62}$ See generally "Accord on Fire and Building Safety in Bangladesh" Accord on Fire and Building Safety in Bangladesh (13 May 2013), online: Accord <http://bangladeshaccord.org/wp-content/uploads/2013/10/ the accord.pdf> at Articles 12-15; "Members Agreement" Alliance for Bangladesh Worker Safety (2013), online: Alliance $<$ http://www.bangladeshworkersafety.org/files/Alliance-Member-Agreement-FINAL.pdf> at Article 6.2(i).

${ }^{63}$ Johns, supra note 11 at 898.

${ }^{64}$ Campbell Jones, Martin Parker \& René ten Bos, Business Ethics: A Critical Approach (New York: Routledge, 2005) at 123.

${ }^{65}$ Addo, supra note 56 at 107.
} 
Since MNEs operate in multiple jurisdictions, they do not apply standards beyond what is required by the laws of the host state. ${ }^{66}$ MNEs are reluctant to accept more responsibility unless legally compelled, or if a disaster can harm the MNE's image. Additionally, even if the laws of the State where the parent company is incorporated is more rigid than the host state, the strict laws of the home state cannot be transplanted to the host. This would violate the territorial principle of international law, which stipulates that each sovereign State has exclusive jurisdiction over the activities occurring within its borders. ${ }^{67}$ To contextualize, since LCL is incorporated under the laws of Ontario, Canada, its operations overseas will not be governed by Canadian laws even if it accords more protection to foreign employees. Rather, its conduct in Bangladesh will be governed by the laws of Bangladesh, and it is in this manner the sovereignty of one State remains inviolate.

Since laws cannot be transplanted between nations, and because international law does not view MNEs as its subjects, it has been suggested that MNEs are in a better position to manage risks and regulate themselves. Since MNEs bring vital economic development to host states, it is less likely that the host state would institute legal proceedings against an MNE. Therefore, since society seeks help from the law to maintain order, ${ }^{68}$ in chaotic events, such as Rana Plaza, how does the law hold the offender accountable? It is now that I arrive at the heart of my Thesis and turn to the law of torts. Since I have explained why international law and voluntary codes are ineffective, I will discuss how courts hold corporations accountable, and

\footnotetext{
${ }^{66} \mathrm{Ibid}$ at $11-13$.

${ }^{67}$ Byers, supra note 9 at 5-6; Also see Betina Kuzmarov, "Unilateral Acts in International Relations: Accepting the Limits of International Law" (2005) 8 YB New Zealand Juris 77; Also see United States of America v Lépine, [1994] 1 SCR 286.

${ }^{68} \mathrm{Ibid}$ at $71-73$.
} 
examine the legal relevance of limited liability, which will segue into a discussion of enterprise liability and offer an avenue of holding MNEs liable.

\section{C — THE DISTINCT LEGAL PERSONS: ENTITY LAW \& LIMITED LIABILITY}

Salomon said that a corporation is a legal entity distinct from its shareholders and that a parent corporation is a legal entity distinct from its wholly owned subsidiary. ${ }^{69}$ The separate legal personality of corporations is known as entity law, which has also been supported by the development of limited liability. ${ }^{70}$ Both limited liability and corporate personhood are privileges that are granted by the State. ${ }^{71}$ From Salomon, it is evident that a corporation can be held liable for misconduct. However, I am not concerned with whether a corporation can be held liable for tortious conduct; rather, my inquiry is whether one corporation can be held liable for misconduct occurring in a facility unowned by the corporation on whom liability is sought to be imposed. Limited liability is a "fundamental principle" and a "traditional cornerstone" in corporate law, which limits the liability of a shareholder to the amount the shareholder invested. ${ }^{72}$ While limited liability firmly established itself in common law jurisdictions by the first half of the nineteenth century, Salomon further solidified this concept. As shareholders became confident that their personal wealth would be unavailable to creditors, they became inclined to invest in

\footnotetext{
${ }^{69}$ Salomon, supra note 1 at 43; To serve as a brief reminder, a 'subsidiary' is a corporation in which another corporation (usually the parent company) has a controlling interest. This control derives by the parent company's ownership of more than one-half the voting stock, see Chapter 1, supra at note 23.

${ }^{70}$ Phillip Blumberg, “Accountability of Multinational Corporations: The Barriers Presented by the Concepts of Corporate Juridical Entity” (2000-2001) 24 Hastings Int'1 \& Comp L Rev 297 at 301 [Blumberg: Barriers]; See Chapter 2, supra at 29-30.

${ }^{71}$ Robert Hamilton, “The Corporate Entity” (1970) 49 Tex L Rev 979 at 981.

${ }^{72}$ Frank Easterbrook \& Daniel Fischel, "Limited Liability and the Corporation” (1985) 52 U Chicago L Rev 89 at 89 [Easterbrook \& Fischel]; Phillip Blumberg, "Limited Liability and Corporate Groups" (1985-1986) 11 J Corp L 574 [Blumberg: Limited Liability]; John Swain and Edwin Aguilar comment, "[Limited liability] is a bedrock proposition of corporate law that a shareholder's risk of loss is generally limited to the amount of the shareholder's investment," at John Swain \& Edwin Aguilar, "Piercing the Veil to Assert Personal Jurisdiction Over Corporate Affiliates: An Empirical Study of the Cannon Doctrine" (2004) 84 BUL Rev 445 at 446.
} 
corporations. ${ }^{73}$ Since the goal of shareholders is to extract "the largest possible return on their investments," and since limited liability accorded financial protection to their personal assets, shareholders could not resist investing in corporations. ${ }^{74}$ It is the principles of limited liability and separate legal personality that protects a corporation from the liabilities of an associated corporation; thus, a parent company is not liable for the misconduct of its subsidiary, and this is held sacred in entity law. ${ }^{75}$

While limited liability is a fundamental principle of corporate law, it is not absolute. Courts occasionally "pierce the corporate veil," which requires shareholders to compensate victims for the misconduct of an associated corporation. ${ }^{76}$ Justice Benjamin Cardozo famously quoted that veil piercing is "enveloped in the mists of metaphor." 77 There is consensus that "piercing" is the most confusing and the most litigated realm of corporate law, and as Frank Easterbrook and Daniel Fischel comment, "Like lightning, it is rare, severe, and unprincipled."78 Though it has been said that courts are more willing to pierce the corporate veil when the owner is a corporation, in reality this is not accurate. ${ }^{79}$ Though exceptional, veil piercing occurs and the separate legal personality of a corporation is disregarded in the following three circumstances:

\footnotetext{
${ }^{73}$ Richard Posner, "The Rights of Creditors of Affiliated Corporations” (1976) 43 U Chicago L Rev 499 at 502.

${ }^{74}$ Jonathan Landers, “A Unified Approach to Parent, Subsidiary, and Affiliate Questions in Bankruptcy" (1975) 42

U Chicago L Rev 589 at 591 [Landers].

${ }^{75}$ Easterbrook \& Fischel, supra note 72 at 93.

${ }^{76}$ Ibid at 89.

77 Berkey v Third Avenue Railway Company, 155 NE 914 at 917 (1927).

${ }^{78}$ Easterbrook \& Fischel, supra note 72 at 89; Robert Thompson, "Piercing the Corporate Veil: An Empirical Study" (1990-1991) 76 Cornell L Rev 1036 at 1036 [Thompson]; There has been extensive academic interest in "piercing," see William Callison, "Rationalizing Limited Liability and Veil Piercing" (2003) 58 Bus Law 1063; Franklin Gevurtz, "Piercing Piercing: An Attempt to Lift the Veil of Confusion Surrounding the Doctrine of Piercing the Corporate Veil" (1997) 76 Or L Rev 853; Nina Mendelson, "A Control-Based Approach to Shareholder Liability for Corporate Torts" (2002) 102 Colum L Rev 1203.

${ }^{79}$ Thompson, ibid at 1056.
} 
where the corporation lacks a separate identity, where the corporation acts as an agent of the principal (parent company), and where statute provides. ${ }^{80}$

\section{i. Lack of Separate Independent Identity}

The first scenario when the separate legal personality of a corporation can be disregarded is when it can be demonstrated that the corporation lacks an independent identity distinct from the parent. ${ }^{81}$ This can be shown by adducing evidence of a parent company's excessive control over the subsidiary. Thus, what must be shown is that the subsidiary is "completely dominated and controlled and being used as a shield for fraudulent or improper conduct." 82

However, courts have said that even $100 \%$ stock ownership of a subsidiary is insufficient to impose liability on the parent company. 83 Therefore, the extent of control that must be demonstrated is that the subsidiary does not function independently and that it lacks a "will, or existence of its own." ${ }^{44}$ As in, the subsidiary is not a separate legal person. To further simplify, the parent company will be held liable if the subsidiary "is under the complete control of the parent and is nothing more than a conduit used by the parent to avoid liability." 85 In a recent precedent setting decision, Justice Carole Brown of the Ontario Superior Court of Justice cited numerous factors the courts should consider to offset claims of separate legal identity, which I will discuss below and more thoroughly in Chapter $4 .{ }^{86}$

\footnotetext{
${ }^{80}$ Blumberg: Barriers, supra note 70 at 304-308.

${ }^{81}$ Ibid at 305.

${ }^{82} 642947$ Ontario Ltd v Fleischer, [2001] OJ No 4771 at para 68.

${ }^{83}$ Blumberg: Barriers, supra note 70 at 305.

${ }^{84}$ Transamerica Life Insurance Co of Canada v Canada Life Assurance Co, [1996] OJ No 1568 at para 22; Ibid at 306.

${ }^{85}$ Gregorio v Intrans-Corp, [2002] OJ No 5083 at para 28.

${ }^{86}$ Choc v Hudbay Minerals Inc, [2013] OJ No 3375, 2013 ONSC 1414 [hereinafter and referred to as “Hudbay"].
} 


\section{ii. Agency Relationship}

Secondly, separate legal personality will also be disregarded where the corporation has acted as the authorized agent of the parent company ${ }^{87}$ Not only is a demonstration of "control" required, but proof must also be shown that the parent company — the principal — has permitted the subsidiary to act on its behalf — as an agent. ${ }^{88}$ Since the principal has authorized the agent to act on its behalf, the law views the actions of the agent as being the actions of the principal. Therefore, the law holds the principal, which is the parent company, liable.

\section{iii. Provision by Statute}

A third approach in piercing the corporate veil is if it is mandated by statute ${ }^{89}$ Primarily, this is done to prevent corporations from avoiding liability because they often use intricate webs of corporate structures; a theme pervasive in the modern business enterprise. ${ }^{90}$ However, corporate veils are pierced only if the relationship is between a parent company and subsidiary. Therefore, this does not speak to whether a corporation can be accountable for misconduct arising in a locally owned facility; as in, the corporation does not own the facility and it is not a subsidiary of the corporation. Additionally, in the globalized modern world, corporate webs include layers of subsidiaries, subcontractors, and other complex legal structures where veil piercing and limited liability, according to Phillip Blumberg, is "anachronistic and dysfunctional." $" 91$

\footnotetext{
${ }^{87}$ Parkland Plumbing \& Heating Ltd v Minaki Lodge Resort, [2009] ONCA 256 at para 51 [Parkland].

${ }^{88}$ Blumberg: Barriers, supra note 70 at 307.

${ }^{89}$ Parkland, supra note 87.

${ }^{90}$ Blumberg: Barriers, supra note 70 at 309.

${ }^{91}$ Phillip Blumberg, "The Transformation of Modern Corporation Law: The Law of Corporate Groups" (2004-2005) 37 Conn L Rev 605 at 608 [Blumberg: Corporate Groups].
} 
The most unfortunate part is that limited liability induces corporations to engage in risky activities without bearing the cost. ${ }^{92}$ Therefore, corporations can delegate risky activities onto subsidiaries because they are shielded from liability. ${ }^{93}$ Thus, limited liability and the act of transferring risky activities onto subsidiaries, creates a "moral hazard." 94 Essentially, managers can take risks, and if harm results, they are shielded from liability, and it is this 'shield from liability' that permitted them to take the risk in the first place. Nonetheless, limited liability induces shareholders to invest in corporations. ${ }^{95}$ Thus, this insulation from liability encourages shareholders to spend little to no money on precautions against preventable accidents, while permitting them to engage in risky activities. ${ }^{96}$

Presently, corporations are "complex business enterprise[s]" that are "collectively conducted by interrelated and intertwined juridical entities" with one corporation as the mastermind. ${ }^{97}$ The principles of limited liability and "piercing the corporate veil" are unduly formalistic, and it has proven to be a failure because it is applied in an unpredictable manner. ${ }^{98}$ Moreover, this unpredictability has led to thousands of incompatible cases each year.

92 Easterbrook \& Fischel, supra note 72 at 103-104; David Leebron, "Limited Liability, Tort Victims, and Creditors" (1991) 91 Colum L Rev 1565 at 1575.

${ }^{93}$ Henry Hansmann \& Reinier Kraakman, "Toward Unlimited Shareholder Liability for Corporate Torts" (1991) 100 Yale LJ 1879 at 1881 [Hansmann \& Kraakman].

${ }^{94}$ Easterbrook \& Fischel, supra note 72 at 111.

${ }^{95}$ Hansmann \& Kraakman, supra note 93 at 1883.

${ }^{96} \mathrm{Ibid}$ at 1882.

${ }^{97}$ Blumberg: Corporate Groups, supra note 91 at 609.

${ }^{98} \mathrm{Ibid}$ at 611-612; Phillip Blumberg comments, It does not contribute to legal understanding because it is an intellectual construct, divorced from business realities. The metaphors are no more than conclusory terms, affording little understanding of the considerations and policies underlying the court's actions and little help in predicting results in future cases [...] As a result, we are faced with hundreds of decisions that are irreconcilable and not entirely comprehensible. Few areas of the law have been so sharply criticized by commentators.

At Phillip Blumberg, The Law of Corporate Groups: Procedural Problems in the Law of Parent and Subsidiary Corporations (Boston: Little, Brown and Company, 1983) at 8. 
Additionally, with learned counsel, today's MNEs can circumvent veil piercing by making sure that its conduct does not fall within one of the excepted criteria. ${ }^{99}$ Therefore, a corporation's veil cannot be pierced. By complying with a modicum of corporate formalities, a subsidiary can demonstrate that it is an independent entity distinct from the parent company and that its use is not fraudulent. ${ }^{100}$ Therefore, if a subsidiary and a parent company maneuver the legal relationship carefully, liability in a "piercing" claim is less probable. ${ }^{101}$

While this may indicate a "sham" corporation, where a shareholder establishes a corporation to shield his personal assets, this would be extremely difficult to prove of a corporation with expert counsel. ${ }^{102}$ Additionally, this may not qualify for fraudulent or improper conduct, as the Ontario Court of Appeal has declared, "[T]he corporate veil should be pierced not where a corporation has misappropriated funds but where the very use of the corporation is to hide that misappropriation; that is, the company structure is used to avoid or conceal liability for the impropriety." ${ }^{.03}$ As in, the complainant must demonstrate not only that the corporation was being used for fraudulent purposes, but that the very reason the corporation was established was to conceal fraudulent activity, which is a more rigorous requirement.

\footnotetext{
${ }^{99}$ Meredith Dearborn, "Enterprise Liability: Reviewing and Revitalizing Liability for Corporate Groups” (2009) 97 Cal L Rev 195 at 208 [Dearborn].

${ }^{100}$ Blumberg: Corporate Groups, supra note 91 at 612.

${ }^{101}$ Phillip Blumberg's voluminous work in this area is illuminating. See Phillip Blumberg, The Law of Corporate Groups: Problems of Parent and Subsidiary Corporations Under Statutory Law of General Application (Boston: Little, Brown \& Company, 1989); Phillip Blumberg \& Kurt Strasser, The Law of Corporate Groups: Problem of Parent and Subsidiary Corporations Under Statutory Law Specifically Applying Enterprise Principles (Boston: Little, Brown \& Company, 1992); Phillip Blumberg, The Multinational Challenge to Corporation Law: The Search for a New Corporate Personality (New York: Oxford University Press, 1993); Phillip Blumberg, "Limited Liability and Corporate Groups" (1985-1986) 11 J Corp L 573; Blumberg: Corporate Groups, supra note 91.

102 Dearborn, supra note 99 at 208.

103 Shoppers Drug Mart Inc v 6470360 Canada Inc (Energyshop Consulting Inc/Powerhouse Energy Management Inc), 2014 ONCA 85 at para 42.
} 
Entity law's formalistic nature shields subsidiaries and parent companies from liability, and disregards the economic relationship between the entities. There exists an overarching economic relationship among the separate, yet interconnected, entities. ${ }^{104}$ What should be understood is that limited liability was a political concept that shielded shareholders from the financial liability incurred by a corporation. However, since then, changes in technology and knowledge have altered the fabric of business enterprises that are operating overseas and are party to mass litigation. ${ }^{105}$ Additionally, empirical data suggests that courts are hesitant in piercing the corporate veil, and plaintiffs are only successful in $40 \%$ of cases. ${ }^{106}$ Therefore, in the globalized world when corporations are operating an intricate web of subsidiaries, the interconnected relationship between corporations justifies the need to consider the economic relationship of the companies.

This section has cogently demonstrated that entity law can presently not address the realities of today's MNEs, which contain corporate structures of incredible complexity. The formalistic nature of entity law ignores the economic structure of MNEs, which renders entity law anachronistic. Moreover, it is an exceptional rarity that a parent corporation is found liable for the misconduct of its subsidiary. Since corporations are the dominant form of business, the ascription of liability should not be elusive or shielded by semantic formulations. Rather, since corporations have transformed into MNEs and are operating across multiple jurisdictions, a framework less formalistic than entity law is required. More importantly, Rana Plaza was not a subsidiary of LCL, which makes imposing liability on the latter an impossibility. It is at this

\footnotetext{
${ }^{104}$ Adolf Berle Jr., "The Theory of Enterprise Entity” (1947) 47 Colum L Rev 343 at 343 [Berle].

105 Phillip Blumberg: Corporate Groups, supra note 91 at 607; Hansmann \& Kraakman, supra note 93 at 1880.

106 Thompson, supra note 78 at 1048.
} 
juncture that enterprise liability has been proposed to compensate for the shortcomings of entity law because it is considerate of the economic relationship between corporations.

\section{D - THE ENTERPRISE SOLUTION}

Historically, theories of enterprise liability have been monumentally influential in the development of statutory and common law rules. ${ }^{107}$ In reference to common law, enterprise liability's impact on cases of products liability in the United States cannot be understated, as it expanded the liability of manufacturers. ${ }^{108}$ In the case of vicarious liability, which is of paramount importance to my case study of Rana Plaza, enterprise theory has also been invoked. William Douglas has argued, "[T]he hazards of a business should be borne by the business directly," and I will expand on this further in the following Chapter where I import the case of Bazley v Curry. ${ }^{109}$

In the United Kingdom, enterprise theory is credited for the promulgation of the Workmen's Compensation Act 1897. After enactment, the business enterprise was held responsible for industrial injuries employees suffered, stipulating, "Where a person, on his own responsibility and for his own profit, sets in motion agencies which create risks for others, he ought to be civilly responsible for the consequences of what he does." ${ }^{110}$ At the same time,

Oliver Wendell Holmes Jr. mentioned enterprise liability, recognizing the limitations of entity law. ${ }^{111}$ Then, fifty years later, Adolf Berle proposed that courts should disregard legal fictions

\footnotetext{
107 Douglas Brodie, Enterprise Liability and the Common Law (New York: Cambridge University Press, 2010) at 2 [Brodie].

108 George Priest, "The Invention of Enterprise Liability: A Critical History of the Intellectual Foundations of Modern Tort Law” (1985) 14 J Legal Stud 461 at 462.

109 William Douglas, "Vicarious Liability and Administration of Risk” (1929) 38 Yale LJ 584 at 586.

110 Brodie, supra note 107 at 3.

111 Oliver Wendell Holmes Jr., “The Path of the Law” (1897) 10 Harv L Rev 457.
} 
and adopt a more pragmatic view of the corporate enterprise. ${ }^{112}$ Berle viewed MNEs as an economic whole as opposed to an "artificial mystic personality."113 Enterprise theory’s moral premise is that when an enterprise injures another in its path to obtain profit, it should be legally obligated to compensate the victim. ${ }^{114}$ That is, since the parent company is profiting from the activities of its subsidiaries, the parent company should be held liable for the subsidiary's misconduct. Therefore, in contrast to the formalistic nature of entity law, enterprise theory is more considerate of the economic realities of corporations and their subsidiaries.

\section{i. What Once was Should Probably Not Dictate the Future}

A legal entity is not the same as an economic entity. As Maurice Dix comments, "The idea behind an economic entity is joinder or merger of activity — unity of life — in the goal of the common [...] enterprise." 115 Simply put, instead of viewing MNEs as separate legal entities, the corporate group is considered a single economic unit that is unified for a common purpose. ${ }^{116}$ Theoretically, since a subsidiary acts to the benefit of the parent company, enterprise liability holds the parent company liable because it profits from the activities of the subsidiary. ${ }^{117}$ Kurt Strasser's observation is luminous:

${ }^{112}$ Adolf Berle Jr., "The Theory of Enterprise Entity” (1947) 47 Colum L Rev 343 at 343.

${ }^{113}$ Ibid at 345.

114 Jane Stapleton, Product Liability (London: Butterworths, 1994) at 186.

${ }^{115}$ Maurice Dix, “The Economic Entity” (1953) 22 Fordham L Rev 254 at 255; Also see Landers, supra note 74.

${ }^{116}$ Christopher Stone, "The Place of Enterprise Liability in the Control of Corporate Conduct" (1980) 90 Yale LJ 1 at 8-9; Guido Calabresi offered an alternative to enterprise liability, offering an economic analysis of tort law, at Guido Calabresi, "Some Thoughts on Risk Distribution and the Law of Torts" (1961) 70 Yale LJ 499.

${ }^{117}$ Kurt Strasser, "Piercing the Veil in Corporate Groups" (2004-2005) 37 Conn L Rev 637 at 638-639 [Strasser]. Strasser further notes at 639 ,

The various companies in the corporate group are really fragments that collectively conduct the integrated enterprise under the coordination of the parent. Within corporate groups, many of the contemporary economic efficiency justifications for limited liability do not apply, and neither should the rules for applying the liability or determining its outer boundary. 
By looking to the whole business, rather than its constituent separate corporate entities, [enterprise liability] avoids completely a direct discussion of the policies of limited liability as it focuses on the business enterprise rather than separate liability rules for the individual corporate entity and its corporate parent shareholders. ${ }^{118}$ That is, enterprise theory imposes liability based on economic patterns rather than yielding to entity law and the concept of separate legal personality. ${ }^{119}$ Based on empirically conducted research, Robert Thompson concludes,

The various arguments for limited liability do not have much impact in the parentsubsidiary situation $[\ldots]$ No adverse diversification effects appear that would lead to over deterrence or excessive monitoring. Yet externalization of some of the costs of the business clearly does occur. Even if piercing would be harsh to a passive parent corporation that did not participate in the wrongful action, it would seem to be outweighed by the harshness to those injured. ${ }^{120}$

Based on the foregoing discussion, it becomes evident that enterprise liability fills the void that entity law creates, by considering the overall economic makeup of MNEs. Research shows that courts occasionally shift their analysis on the enterprise as a whole, instead of limiting themselves to the rigid contours of entity law. ${ }^{121}$ Adopting enterprise principles heralds the legal system's response to the challenges "presented by the inadequacy of traditional legal doctrines"

\footnotetext{
118 Ibid at 647.

119 Lawrence Gower, Modern Company Law, 3d ed (London: Sweet \& Maxwell, 1969) at 216.

${ }^{120}$ Robert Thompson, "Unpacking Limited Liability: Direct and Vicarious Liability of Corporate Participants for Torts of the Enterprise"(1994) 47 Vand L Rev 1 at 40.

121 Toronto (City of) v Famous Players' Canadian Corp, [1935] OR 314; Saskatchewan Economic Development Corp v Patterson-Boyd Manufacturing Corp, PB Fabricators Ltd, and Western Metal \& Supply Co Ltd, [1981] 2 WWR 40; Atco Ltd v Calgary Power Ltd, [1982] 2 SCR 557; and Olson v Sprung Instant Greenhouses Ltd, [1985] 41 Alta LR (2d) 325.
} 
to fully address the "problems presented by the complexities of modern society." 122 While

enterprise liability is currently not the dominant form of legal inquiry in MNE misconduct, it has gained traction in several jurisdictions, including Germany, Brazil, Portugal, Italy, India, the United Kingdom, the United States, and most importantly for my Thesis, Canada. ${ }^{123}$

\section{ii. What Hudbay Said}

In keeping with enterprise liability, the Ontario Superior Court of Justice, in Hudbay, has allowed plaintiffs from the Mayan Q'eqchi community of Guatemala to pursue litigation against HudBay Minerals Incorporated, a corporation headquartered in Ontario, Canada, for the misconduct of its $98.2 \%$ owned subsidiary, Compania Guatemalteca De Niguel. ${ }^{124}$ Justice Carole Brown outlined a list of non-exhaustive factors indicating a subsidiary's lack of a separate identity. While she did not explicitly mention 'enterprise theory,' the language of the decision was reminiscent of enterprise principles. If employees from the parent company are in charge of the subsidiary's operations and if the parent company effectively controls the subsidiary, then it will serve as adequate evidence that the subsidiary lacks a separate identity. ${ }^{125}$ I pronounce again that Rana Plaza was not a subsidiary of LCL. Therefore, while the outlined factors may seem inapplicable to my case study, they are insightful when I demonstrate the level of control LCL exerted over Rana Plaza even though the latter was locally owned.

\footnotetext{
122 Blumberg: Corporate Groups, supra note 91 at 614.

123 Blumberg: Barriers, supra note 70 at 317-318; Dearborn, supra note 99 at 214-230; Strasser, supra note 117 at 646-648; For an excellent review of the inception, rise, near extinction, and exhumation of enterprise liability, see generally Virginia Nolan \& Edmund Ursin, Understanding Enterprise Liability: Rethinking Tort Reform for the Twenty-first Century (Philadelphia: Temple University Press, 1995) at 3-7 (inception), 13-23 (rise), 125-132 (near extinction), and 147-149 (exhumation); For a list of cases adopting enterprise principles in Canada, refer to note 121 supra.

${ }^{124}$ Hudbay, supra note 86 at paras $4 \& 10$.

${ }^{125}$ Hudbay, supra note 86 at paras 67-69.
} 


\section{D - RESEARCH IMPLICATIONS}

This Chapter has highlighted the lacunae that exists in the regulation of multinational enterprises. I have alluded to international law and its inability to govern the conduct of MNEs on the grounds that it views them as its objects. Therefore, treaties enacted by States do not apply to MNEs. While there exists soft law instruments for this purpose, their primary subjects are, again, States. Additionally, soft law does not have sanctioning abilities even though it is binding. Nonetheless, MNEs often adopt voluntary codes so that an injury causing accident does not negatively affect its image; yet, even voluntary codes do not have the ability to monitor compliance. Furthermore, the rigid formalistic nature of entity law has become anachronistic because of the rapid transformation of modern MNEs. To address the deficiencies of entity law, enterprise liability has been proposed, whose acceptance is slowly growing in a number of jurisdictions, but for the purposes of Rana Plaza, it also is burdened with limitations.

Overall, the above comprehensive discussion about entity law, piercing the corporate veil and its shortcomings, and enterprise theory's objective in bridging the gap between law and economics has left yet another gap in governance. That is, complaints can be lodged against a parent company for the actions of its subsidiary, which indicates partial or whole ownership by

the parent company. However, this fails to consider a scenario when there is no ownership, which is the crux of the issue in Rana Plaza. It is at the crossroads of law, economics, and the removed ownership from the parent company where a decision rendered by the Supreme Court of Canada is of paramount importance. This will inform my analysis in delineating how LCL could potentially be held liable for the deaths and injuries resulting from the collapse of Rana Plaza. 


\section{IV - THE MERGER OF LINKED CONNECTIONS}

"Corporations have neither bodies to be punished, nor souls to be condemned. They therefore do as they like."

- Baron Edward Thurlow ${ }^{1}$

This Chapter will begin with a discussion of Bazley, analyzing how the case could be used in the disquisition of whether LCL can be held accountable for the deaths and injuries resulting from the collapse of Rana Plaza. Since Rana Plaza is not owned by LCL, I aim to demonstrate negligence on the part of Adnan, and trace liability vicariously to LCL on the grounds that Rana Plaza and LCL were involved in the same economic enterprise. Therefore, I will begin with an exploration of Bazley, reveal Adnan's negligence, and delineate how Rana Plaza and LCL were involved in the same enterprise for which it would not be unjust to hold LCL liable.

\section{A - THE BAZLEY DECISION}

In 1999, the SCC delivered a landmark decision, consolidating enterprise liability and vicarious liability in the employment context. ${ }^{2}$ Vicarious liability, a form of strict liability, is imposing liability on person $\mathrm{A}$ for the actionable conduct of person $\mathrm{B}$, even though person $\mathrm{A}$ is free of fault and blameworthiness. ${ }^{3}$ Patrick Atiyah outlines three factors to be considered before imposing vicarious liability: first, the misconduct or omission is done by a party, but liability is sought to be imposed on another party; second, there is a relationship between the tortfeasor and

\footnotetext{
${ }^{1}$ Baron Edward Thurlow was the Lord Chancellor of Great Britain from 1778-1783.

${ }^{2}$ Douglas Brodie, Enterprise Liability and the Common Law (New York: Cambridge University Press, 2010) at 1 [Brodie].

${ }^{3}$ John Fleming, The Law of Torts, 9th ed (Sydney: LBC Information Services, 1998) at 409 [Fleming]; Also see Attila Ataner, "How Strict is Vicarious Liability? Reassessing the Enterprise Risk Theory" (2006) 64 UT Fac L Rev 63 at 66; Stephen Waddams also suggests, "Vicarious liability is a form of strict liability, in that employers have been held liable for tortious acts of employees without proof of any fault on the employer's part," at Stephen Waddams, Dimensions of Private Law (New York: Cambridge University Press, 2003) at 102.
} 
the defendant; and third, there is a connection between the tortious act, or omission, and the relationship that exists between the tortfeasor and the defendant. ${ }^{4}$ In Bazley, the SCC held that since the employer introduced an enterprise into the community carrying certain risks, it is fair that he is held vicariously liable because those risks caused injury to someone. ${ }^{5}$ This is done because it was the enterprise that created the risk from where injury resulted. That is, in the absence of that enterprise, the risk would not have persisted, and since the risk is connected to the enterprise, it is fair that the enterprise is held liable.

\section{i. Guidelines from Bazley}

In Bazley, the SCC relied on the Salmond test to determine whether the employer should be held vicariously liable. The Salmond test declares that an employer should be vicariously liable for employee misconduct falling within the "scope of employment." 6 This consists of acts that are authorized by the employer, or acts that are not authorized by the employer but are connected to authorized acts that they are considered modes of doing what has been authorized. The court did not explore whether the conduct in question was authorized by the employer, as both parties agreed that it was an unauthorized act; therefore, the analysis focused on the second branch of the Salmond test. ${ }^{7}$

Since part two of the test is ambiguous, the SCC examined and grouped previous cases into three categories for which employers were justly held vicariously liable: where an employee

${ }^{4}$ Patrick Atiyah, Vicarious Liability in the Law of Torts (London: Butterworth \& Co Ltd, 1967) at 3 [Atiyah].

${ }^{5}$ Bazley v Curry, [1999] 2 SCR 534 at para 31 [Bazley]; Brodie, supra note 2 at 2-7.

${ }^{6}$ Robert Heuston \& Richard Buckley, Salmond and Heuston on the Law of Torts, 19th ed (London: Sweet \& Maxwell, 1987) at 521-522 [Heuston \& Buckley]; The 'Salmond test' is a common law, and commonly used, test in determination of vicarious liability.

${ }^{7}$ Bazley, supra note 5 at para 10; That is, whether the acts are unauthorized by the employer, but are connected to authorized acts that they are considered modes - albeit improper modes - of doing what has been rightly authorized. 
acted to further the employer's aims; where the employer created a situation of friction; and cases concerning dishonest employees. While the three groups of cases may seem dissimilar, the commonality is that in each category it was the employer's enterprise that created the risk from where the employee's misconduct resulted and injured another party. ${ }^{8}$

\section{ii. Vicarious Liability}

From the beginning, vicarious liability has been intertwined with policy. ${ }^{9}$ In early English law, the master was liable for every wrongdoing of his servant, wife, and inanimate objects. This dramatically changed by the $16^{\text {th }}$ century, at which point, the master was only liable for acts he ordered. ${ }^{10}$ However, with the slow growth of international commerce and the changing nature of business in the 1700s, the master's liability changed again. People no longer believed that a master could maintain control over all elements of modern industry; thus, two policy considerations emerged to expand vicarious liability. First, there emerged a social interest in allowing a tort victim to seek reparation from a solvent defendant. Second, there emerged the idea that business enterprises should not be unduly burdened. ${ }^{11}$ Then, in the $20^{\text {th }}$ century, vicarious liability was expanded to include a broader class of cases with "its basis in a combination of policy considerations." 12

\footnotetext{
${ }^{8} \mathrm{Ibid}$ at paras $17 \& 22$.

${ }^{9}$ Fleming, supra note 3 at 409-411; Bazley, supra note 5 at para 26.

${ }^{10}$ Keeton et al, Prosser and Keeton on The Law of Torts, 5th ed (St. Paul, MN: West Publishing Co, 1984) at 500 [Keeton et al].

${ }^{11} \mathrm{Ibid}$; Fleming, supra note 3 at 410.

${ }^{12}$ Fleming, ibid; Vicarious liability was previously held to rest on two logical bases: (1) respondeat superior, where liability was imputed on the employer simply because he is the employee's superior; and (2) qui facit per alium facit per se, where the employer was held vicariously liable for the acts of his employee because the acts were regarded as being authorized by the earlier so that in law the acts of the employee are the acts of the employer, ibid; Also see Atiyah, supra note 4 at Chapter 2; William Douglas, "Vicarious Liability and Administration of Risk" (1929) 38 Yale LJ 584 [Douglas]; Harold Laski, "The Basis of Vicarious Liability" (1916) 26 Yale LJ 105; London Drugs Ltd v Kuehne \& Nagel International Ltd, [1992] 3 SCR 299 at 335-336.
} 


\section{ii.1 - Just \& Practical Remedy}

John Fleming identified two fundamental policies lying at the heart of vicarious liability. First, providing a just and practical remedy for the harm, and second, the deterrence of future harm. ${ }^{13}$ It is important to compensate those injured from the operations of the enterprise. As in, "[A] person who employs others to advance his own economic interest should in fairness be placed under a corresponding liability for losses incurred in the course of the enterprise." ${ }^{14}$ At the heart of tort law lies the idea that the introducer of a risk is liable for injuries he causes and should compensate the injured party. ${ }^{15}$ Page Keeton articulates,

The losses caused by the torts of employees, which as a practical matter are sure to occur in the conduct of the employer's enterprise, are placed upon that enterprise itself, as a required cost of doing business. They are placed upon the employer because, having engaged in an enterprise $[\ldots]$ and sought to profit by it, it is just that he, rather than the innocent injured plaintiff, should bear them. ${ }^{16}$

Inarguably, vicarious liability is fair in this sense because it holds liable the person who profits from the services of people he employed. Furthermore, Justice Benjamin Cardozo declared, "The risk reasonably to be perceived defines the duty to be obeyed, and risk imports relation; it is risk to another or to others within the range of apprehension.." ${ }^{17}$ Moreover, the most important social goal served by vicarious liability is compensating victims. This improves a victim's chance of

\footnotetext{
${ }^{13}$ Fleming, ibid at 410; Also see Bazley, supra note 5 at para 29.

${ }^{14}$ Fleming, ibid; Also see Alan Sykes, "The Boundaries of Vicarious Liability: An Economic Analysis of the Scope of Employment Rule and Related Legal Doctrines” (1988) 101 Harv L Rev 563.

15 Bazley, supra note 5 at para 30; Fleming, supra note 3 at 3-4.

${ }^{16}$ Keeton et al, supra note 10 at 500 [emphasis added].

${ }^{17}$ Helen Palsgraf v The Long Island Railroad Company, 248 NY 339 at 344 (1928) [Palsgraf].
} 
recovering damages from a solvent defendant, and in this sense, vicarious liability is just and practical. $^{18}$

\section{ii. 2 - Deterrence of Future Harm}

The second objective of vicarious liability is general deterrence. Imposing responsibility on the employer for the wrongful conduct of the employee, even when the former is not blameworthy, would deter future wrongdoing. ${ }^{19}$ This is grounded in the belief that it is the employer who is in a better position to reduce future accidents through supervision and organization. As in, holding the employer liable for tortious conduct that he did not commit would encourage the employer to take precautionary steps in reducing future harm.

\section{iii. Principles of Enterprise in Vicarious Liability}

The above said rationale of vicarious liability begs the question of, in what ways has enterprise principles influenced this form of liability in Canada? Justice Beverley McLachlin (as she then was) explains,

The employer puts in the community an enterprise which carries with it certain risks. When those risks materialize and cause injury to a member of the public despite the employer's reasonable efforts, it is fair that the person or organization that creates the enterprise and hence the risk should bear the loss. ${ }^{20}$

An enterprise carries certain inherent risks, and as such, it should minimize those risks. Since the enterprise is in a better position to prevent accidents through supervision, if harm results, the

\footnotetext{
${ }^{18}$ Bruce Feldthusen, Torts Tomorrow: A Tribute to John Fleming, ed by Nicholas Mullany \& Allen Linden (Sydney: LBC Information Services, 1998) at 224 [Mullany \& Linden]; Also see Fleming, supra note 3 at 410; Bazley, supra note 5 at para 30 .

${ }^{19}$ Bazley, ibid at para 32.

${ }^{20} \mathrm{Ibid}$ at para 31; As of 7 January 2000 (and until time of writing), Justice Beverley McLachlin serves as the Chief Justice of the Supreme Court of Canada.
} 
enterprise should be held liable because it introduced the risk. ${ }^{21}$ In other words, imposing liability on the employer for acts he did not commit is fair because it was the employer that introduced a risk from where harm resulted.

However, the enterprise will not to be liable for every wrongful act of its employee, but only for those acts that the enterprise "creates or exacerbates." 22 Therefore, there must be a connection between the employment enterprise and the resulting harm:

The enterprise and employment must not only provide the locale or the bare opportunity for the employee to commit his or her wrong, it must materially enhance the risk, in the sense of significantly contributing to it, before it is fair to hold the employer vicariously liable..$^{23}$

Furthermore, the SCC has said that even if the connection between the creation or enhancement of the risk and the resulting wrong is "unrelated to the employer's desires," the employer will still be held liable. ${ }^{24}$ However, it is important to identify the connection between creation of a risk and the wrong, otherwise it would transform the employer into an involuntary insurer.

\section{B - INDEPENDENT CONTRACTORS}

The above discussion gives rise to a discrepancy. I have focused on a relationship between employers and employees, begging the question of whether LCL is Adnan's employer, or was Adnan an independent contractor? Additionally, Rana Plaza was a subcontractor, as Pearl Global Industries (hereinafter "PGI") was LCL's original contractor, which only complicates an

\footnotetext{
${ }^{21} \mathrm{Ibid}$ at para 34.

22 Ibid at para 37.

${ }^{23}$ Ibid at para 40 [emphasis omitted].

${ }^{24} \mathrm{Ibid}$ at para 41 [emphasis omitted].
} 
already complex relationship. While the law holds employers liable for the misconduct of their employees, it does not hold, subject to limited exceptions, employers liable for the misconduct of independent contractors. ${ }^{25}$ Vicarious liability is only imposed when the employer has authorized an employee to complete a task, ${ }^{26}$ or when the enterprise has created or exacerbated a risk. Therefore, it has been suggested that the employer is not liable for the acts of an independent contractor because he lacks control over his activities.

The obvious question that then arises is who is an independent contractor? Canadian courts, while conceding that there is no "one conclusive test," ask the central question of whether the person doing the service is in business "on his own account." ${ }^{, 27}$ If he is in business on his own account, then it is a contract for services, which is an independent contractor. If the person is not in business on his own account, then it is a contract of services, which is an employer/employee relationship. The SCC then recommended examining the following non-exhaustive factors: the degree of control, whether the worker provides his own equipment, whether the worker hires his own helpers, and the worker's opportunity for profit in the performance of his tasks, but stressed the importance of exploring the "total relationship of the parties." ${ }^{28}$ In the case of Rana Plaza, I examine the additional factor of the level of knowledge in the mind of LCL regarding the work being done at New Wave.

\footnotetext{
${ }^{25}$ Allen Linden \& Bruce Feldthusen, Canadian Tort Law, 9th ed (Markham, ON: LexisNexis Canada Inc, 2011) at 564 [Linden \& Feldthusen]; 671122 Ontario Ltd v Sagaz Industries Canada Inc, [2001] 2 SCR 983 at para 33 [Sagaz]; Fleming, supra note 3 at 433; For exceptions, see Atiyah, supra note 4 at 327-378.

${ }^{26}$ Robert Flannigan, “Enterprise Control: The Servant-Independent Contractor Distinction” (1987) 37 UTLJ 25 at 30-31.

${ }^{27}$ Sagaz, supra note 25 at paras $44 \& 46-47$; To quote Justice Major, "[W]hether the person who has been engaged to perform the services is performing them as a person in business on his own account." Also see Fleming, supra note 3 at 416 .

${ }^{28}$ Sagaz, ibid at paras 46-48.
} 
Therefore, in order to hold LCL vicariously liable, I would need to prove, first, some form of loss resulting from misconduct that is not committed by LCL. Second, because of an employment relationship between LCL and Adnan, since LCL introduced a risk into the community ripening into harm, it should be held liable as both parties were involved in the same economic enterprise.

\section{C - NEGLIGENCE AT RANA PLAZA}

The law of negligence, one of the most important fields in tort liability, has manifold purposes, one of which is compensating an injured party for the misfeasance, or nonfeasance, of a person. ${ }^{29}$ While there is disagreement regarding the components of a claim in negligence, John Fleming has put forward five elements. He says that (1) an injury must have been suffered by the party seeking remedy; (2) the law must recognize that the defendant owes a duty of care to the plaintiff; (3) the defendant's conduct must be in breach of a standard of care; (4) the conduct of the defendant must have been a proximate cause for the loss; and (5) if the plaintiff's conduct contributed to the loss, he cannot seek remedy from the defendant. ${ }^{30}$ Allen Linden and Bruce Feldthusen have also recommended exploring whether the damage suffered by the plaintiff is caused by the conduct of the defendant. ${ }^{31}$ I will now consider these elements in seriatim and demonstrate how Adnan was negligent. Afterwards, I will show how LCL could be held vicariously liable for Adnan's misconduct because LCL and Rana Plaza were involved in the same economic enterprise.

\footnotetext{
${ }^{29}$ Linden \& Feldthusen, supra note 25 at 113; Fleming, supra note 3 at 113-114.

${ }^{30}$ Fleming, ibid at 115-116; I only briefly consider the issue of "proximate cause," which I explain infra at note 69. As I explain below, since the defendant in this case is the employer (Adnan) of the victims, I do not delve into the esoteric questions of proximate cause.

${ }^{31}$ Linden \& Feldthusen, supra note 25 at 115.
} 


\section{i. Injury to the Plaintiff and the Duty of Care Owed by the Defendant}

In the law of negligence, no cause of action arises until damage, which is a loss or injury, has occurred. ${ }^{32}$ Therefore, if the question is asked as to whether employees working at Rana Plaza suffered injury, the answer is 'yes,' as 1,134 persons died, with another 2,500 injuries. ${ }^{33}$ However, the question that then arises is whether the defendant owed the claimants a duty of care. If the defendant does not owe the claimant a duty of care, the law will not impose liability, regardless of how negligent the defendant is. If the law imposes liability on a person who does not owe a duty of care to another, the law of negligence would become overbroad. ${ }^{34}$ Therefore, a person is entitled to act "as negligent as he pleases towards the whole world if he owe[s] no duty to them." 35

This duty arises from a "relation" or "proximity" between the parties, and the classical pronouncement has been the "neighbor test" as declared by Lord James Atkin in Donoghue v Stevenson. ${ }^{36}$ The "neighbor test" has been adopted and later modified by the SCC in Kamloops $v$

\footnotetext{
32 Fleming, supra note 3 at 217; Also see Linden \& Feldthusen, ibid at 116; Vile v Von Wendt, [1979] OJ No 4421 at para 13, 103 DLR (3d) 356.

${ }^{33}$ Tansy Hoskins, "Reliving the Rana Plaza Factory Collapse: A History of Cities in 50 Buildings, Day 22" The Guardian (23 April 2015), online: Guardian News and Media Limited <http://www.theguardian.com/cities/2015/apr/ 23/rana-plaza-factory-collapse-history-cities-50-buildings $>$; In this Chapter, the use of the word "injury" is also held to mean "dead" or "death" unless otherwise stated.

${ }^{34}$ Fleming, supra note 3 at 149; Also see Linden \& Feldthusen, supra note 25 at 287; William Prosser, "Palsgraf Revisited" (1953) 52 Mich L Rev 1 [Prosser]; Robert Heuston, "Donoghue v. Stevenson in Retrospect" (1957) 20 Mod L Rev 1.

${ }^{35}$ La Lievre v Gould, [1893] 1 QB 491 at 2, 57 JP 484.

${ }^{36}$ Fleming, supra note 3 at 151; Lord Atkin declared at Donoghue v Stevenson, [1932] All ER Rep 1 at 11, [1932] AC 562,

The rule that you are to love your neighbor becomes in law you must not injure your neighbor; and the lawyer's question, Who is my neighbor? receives a restricted reply. You must take reasonable care to avoid acts or omissions which you can reasonably foresee would be likely to injure your neighbor. Who, then, in law, is my neighbor? The answer seems to be - persons who are so closely and directly affected by my act that I ought reasonably to have them in contemplation as being so affected when I am directing my mind to the acts or omissions which are called in question.
} 
Neilsen and Cooper $v$ Hobart.$^{37}$ However, I do not delve into the esoteric questions of this test because I am concerned with whether Adnan (the employer), and not a remote defendant or cause, owed a duty of care to his employees, and whether the plaintiffs were unforeseeable. As I demonstrate below, Adnan owed a duty of care to the plaintiffs, and they were not unforeseeable.

In the common law world, and since Bangladesh is a common law country, ${ }^{38}$ it is widely accepted that an employer owes a duty of care to his employees. An employer must not expose his employees to unreasonable risks of harm, and must provide a safe site for employment. ${ }^{39}$ Besides the common law duty, pursuant to Article 86 of the Bangladesh Labour Act, which is the federal statute governing labor relations in Bangladesh, the employer must ensure that, "[A] dangerous condition that $[\ldots]$ is likely to cause physical injury" is avoided..$^{40}$ This provision, along with the common law duty, is proof that an employer in Bangladesh owes a duty of care to his employees.

Since the injured party are employees at Adnan's factory, they are foreseeable plaintiffs. For example, the injured party is not a bystander or passerby who fortuitously witnessed the collapse and suffered nervous shock, which would make him unforeseeable. ${ }^{41}$ Rather, since these are employees at New Wave, it is sufficient to cite Article 86 of the $B L A$ and the common law duty to adduce evidence of Adnan's duty of care.

\footnotetext{
${ }^{37}$ Kamloops v Nielsen, [1984] 2 SCR 2; Cooper v Hobart, [2001] 3 SCR 537.

${ }^{38}$ Paul Mahoney, "The Common Law and Economic Growth: Hayek Might be Right” (2001) 30 J Legal Stud 503 at 524.

39 Wilsons \& Clyde Coal Company Limited v English, [1937] 3 All ER 628; Also see Fleming, supra note 3 at 559-562.

${ }^{40}$ Bangladesh Labour Act, 2006 (Bangladesh), XLII of 2006, at Art 86; Retrieved from <http://www.ilo.org/dyn/ natlex/natlex4.detail?p_lang=en\&p_isn=76402\&p_country=BGD\&p_classification $=01.02>$.

${ }^{41}$ See generally Palsgraf, supra note 17; Also see Prosser, supra note 34.
} 


\section{ii. Was There a Breach in the Standard of Care?}

Since I have established that employees at New Wave were injured, and that the defendant owed a duty of care to the employees, I will now determine whether the employer breached the standard of care. This standard is an objective test generally measured by what a "reasonable person of ordinary prudence" would do if placed in the same situation as the defendant. ${ }^{42}$ Therefore, if the defendant were an accountant or a lawyer, the test of the reasonable person would differ than if the defendant were a laity. ${ }^{43}$ Furthermore, if the defendant were a person with a physical disability, the test would be of what to expect from a reasonable person with the same disability as the defendant ${ }^{44}$ In the context of employment, the standard of care expected of employers is high and this standard has increased substantially within the past twenty years. ${ }^{45}$ Therefore, since the behavior of individuals is incalculable, the circumstances giving rise to a claim in negligence is infinite.

\section{ii.1 - Factors to be Considered}

For society to function seamlessly, not every conduct is a breach in the standard of care.

As in, it can only be held to be a breach of the standard of care when the conduct results in an

\footnotetext{
${ }^{42}$ Fleming, supra note 3 at 117.

${ }^{43}$ Fleming, ibid at 121; As in, courts would ask what a reasonable accountant or lawyer with proficiency expected of them by the public would do if placed in the same situation as the defendant. However, this can vary for physicians, see 121-122.

44 South Australian Ambulance Service v Wahlheim, [1948] HCA 32, 77 CLR 215; The test also takes into account children's innate innocence, allocating more weight to exculpatory evidence, at Fleming, ibid at $126 \& 320-321$; See Yorkton Agricultural \& Industrial Exhibition Association v Morley, [1967] 66 DLR (2d) 37 (where it was held not negligent for an eight-year old boy to be striking matches in a barn); Walmsley v Humenick, [1954] 2 DLR 332 (where it was held not negligent for a five-year old boy to be shooting with arrows); McHale $v$ Watson, [1966] HCA 13, 115 CLR 199 (where it was held not negligent for a twelve-year old to be throwing metal darts in the course of a game).

${ }^{45}$ Bankstown Foundry Proprietary Limited v Braistina, [1986] HCA 20 [Bankstown]; Also see Fleming, supra note 3 at 560 .
} 
unreasonable risk of harm. ${ }^{46}$ This is so because every activity has some degree of danger, but if even a remote chance for injury brings about the liability of individuals, human conduct would be overwhelmingly inhibited. ${ }^{47}$ Therefore, in measuring whether the hazard is unreasonable, courts balance the danger created by the act to the usefulness of the act. If the danger outweighs the usefulness of the act, liability is imposed. ${ }^{48}$

Generally, three factors are considered. First, conduct is not negligent unless there is a recognizable risk of injury causing a reasonable person to take precaution. ${ }^{49}$ That is, the injury that could result from the conduct of the defendant must be a "real risk," so that a reasonable person would not "brush it aside as far-fetched." ${ }^{50}$ Second, if the potential loss is great, even a slight risk of injury gives rise to liability. ${ }^{51}$ Lastly, if the cost of removing the risk is high, liability will not be imposed. For example, an underpass or overpass does not need to be constructed at every railway crossing because there are cheaper ways of communicating the same warning. ${ }^{52}$

\footnotetext{
${ }^{46}$ Fleming, ibid at 127; Also see Mustapaha v Culligan of Canada Limited, [2008] 2 SCR 114 [Mustapha] (where Chief Justice McLachlin relied on this passage); Henry Terry, "Negligence" (1915) 29 Harv L Rev 40; Leon Green, "The Negligence Issue" (1928) 37 Yale LJ 1029.

${ }^{47}$ Fleming, ibid at 127; Linden \& Feldthusen, supra note 25 at 134.

${ }^{48}$ Linden \& Feldthusen, ibid at 134; In other explanatory terms, if all vehicles travelled at 10 kilometers, roads would be safer by a lessened probability of accidents. However, this 'safety' would come at the cost of a depressingly slow movement of traffic; thus, the cost of this safety would be too high; For an interesting analysis, see, United States $v$ Carroll Towing Company, 159 F 2d 169 (2d Cir Ct of App 1947), where Justice Learned Hand said if the probability of loss and the gravity of loss is greater than the cost of taking precautions, a duty of care on the defendant arises.

${ }^{49}$ Fleming, supra note 3 at 127.

${ }^{50}$ Mustapha, supra note 46 at para 13; The Wagon Mound (No 2), [1966] 2 All ER 709 at 719; The leading case in this field is Bolton $v$ Stone, [1951] 1 All ER 1078 (where it was held not negligent to play cricket in close proximity to a populated area because the chance of a ball flying out of the stadium and striking a bystander was very small).

${ }^{51}$ Linden \& Feldthusen, supra note 25 at 138.

${ }^{52}$ Fleming, supra note 3 at 130; Also see Reibl v Hughes, [1980] 2 SCR 880 (where it was held that a doctor need only disclose the "material" and "unusual or special" risk of the operation being administered on the patient).
} 


\section{ii.2 - Was there a Recognizable Risk of Injury?}

Based on the above discussion, what must first be examined is what another reasonable factory owner should have done if faced with a similar situation. On 23 April, a day prior to the collapse of Rana Plaza, cracks two inches deep had formed on the walls of the facility spanning several floors, which prompted Adnan to contact the remaining factory owners and, in a concerted effort, evacuate the building. ${ }^{53}$ An engineer was summoned to inspect the facility who declared it "vulnerable" and recommended sealing off the site. However, on the day of the collapse, Rana Plaza was open and Sohel Rana assured employees and factory owners that the building was safe "for another hundred years." ${ }^{54}$ I refrain from narrating subsequent events, as I have done so compendiously in Chapter 1 .

Rana Plaza was built on hastily filled swampy land using substandard material, and the top four floors were constructed without a legal permit. ${ }^{55}$ Since the facility was built on softer soil without reinforcing columns, Henri Gavin explains that it "[led] to an instability [precipitating into] a collapse." ${ }^{56}$ Adnan, the employer of those inside New Wave, was duty bound to ensure that the site where his employees were working was safe from foreseeable danger. That is, the situation that gave rise to the injury was not unforeseeable, such as a bomb

\footnotetext{
${ }^{53}$ Ker Than, "Bangladesh Building Collapse Due to Shoddy Construction" National Geographic (26 April 2013), online: National Geographic Partners, LLC <http://news.nationalgeographic.com/news/2013/13/130425-bangladeshdhaka-building-collapse-world/> [Than]; "Interview with Jailed Rana Plaza Factory Owner Bazlus Samad Adnan" CBC The Fifth Estate (11 October 2013), online: CBC http://www.cbc.ca/fifth/blog/interview-with-jailed-ranaplaza-factory-owner-bazlus-samad-adnan> [Interview with Adnan].

${ }^{54}$ Jason Motlagh \& Atish Saha, "The Ghosts of Rana Plaza: In Bangladesh, One Year After the Worst Accident in the History of the Garment Industry, Recovery Remains a Fragile Process, Justice Seems Elusive, and Reform has a Long Way to Go" (2014) 90 Va Q Rev 44 at 66 \& 76 [Motlagh \& Saha].

${ }^{55}$ Than, supra note 53.

${ }^{56}$ Henri Gavin is a civil and environmental engineer at Duke University, ibid.
} 
affixed on machinery that no one knew was there. ${ }^{57}$ Rather, it was a foreseeable and avoidable risk because a crack had been sighted the previous day.

In the event one is to suggest that a person who does not have knowledge about structural integrity of a building should not be held liable, what must be remembered is that an engineer was summoned when the crack appeared who declared sealing it off. However, the expert's advice was flouted, as Managers ordered employees to enter the facility and begin work. Therefore, it is not that Adnan did not know of the danger, but that he knew of the danger and failed to take action to ensure the safety of his employees. ${ }^{58}$

A crack that spanned several floors on the structure of the building, coupled with the engineer's suggestion to bar entry, speaks of the weakness in the building's integrity. Therefore, there was a high probability that injury could result because its safety was in question. As a result, not only was the chance of injury not remote, but since it is the site where business is carried on, Adnan's conduct of disregarding expert advice and the danger posed by the crack introduced an unreasonable risk of harm.

\section{ii.2.1 - Can the Potential Loss be Outweighed by the Utility of the Defendant's Conduct?}

The crack on the structure was a real risk, as the engineer would otherwise not recommend sealing off the site. More importantly, the facility would not have been vacated on 23 April. Not everyone in society is proficient in every trade and it is not counted against Adnan that he was not a civil engineer. His fault does not lie in the fact that he was not aware of the potential consequences of the crack. Rather, as I have said earlier, his fault lies in his failure to ensure the

\footnotetext{
${ }^{57}$ See generally O'Reilly v National Rail \& Tramway Appliances Limited, [1966] 1 All ER 499.

${ }^{58}$ See generally Fleming, supra note 3 at 119-121.
} 
safety of his employees from an unreasonable risk of harm even though he was made fully aware of the issue from an expert. ${ }^{59}$

When Adnan became aware of the circumstances on 23 April, it would seem irrational for a reasonable person to think of the risk as farfetched on the grounds of the above discussion. If the question is then asked of what loss could possibly result from the weakened building, the answer is simple — life. While human beings are not delicate creatures, when their opponent is concrete, even the strongest would crumble. Additionally, when the potential for loss is weighed against the utility of Adnan's conduct, he is still found to be negligent as the social usefulness of his conduct is minimal. That is, the usefulness of Adnan's conduct would result in garments being ready for export. However, this usefulness is dwarfed by the importance of human life. Nonetheless, this element of rushing to complete orders becomes important later, when I speak of holding LCL vicariously liable.

\section{ii.2.2 - Would the Cost of Removing the Risk have been Unconscionably High?}

What would the cost have been to remediate the risk? It would not be incorrect to draw a logical inference that delivering garments late would frustrate manufacturers, as LCL repeatedly put pressure on Adnan to deliver merchandise timely. ${ }^{60}$ If suppliers cannot provide garments within the stipulated time, their cost of production increases because the supplier would be required to pay for transportation by air. ${ }^{61}$ While this is another element that becomes crucial when I speak of imposing vicarious liability on LCL, it must be understood that the fear of

\footnotetext{
59 Than, supra note 53.

${ }^{60}$ Interview with Adnan, supra note 53; While it is a logical inference currently, I explain the factual basis of this assertion below.

${ }^{61}$ Paula Alexander, Corporate Social Irresponsibility (New York: Routledge, 2015) at 304-305 [Alexander].
} 
frustrating manufacturers does not negate Adnan's duty of care towards the victims. Therefore, he cannot be exonerated. Though the cost of remedying the risk would probably have burdened commerce - factory owners having to find an alternative venue to fabricate garments, explaining the delay to manufacturers, thereby causing frustration, or transporting garments via air — this cost is minimal when compared to human life. ${ }^{62}$ Therefore, it cannot be accepted that the cost of removing the risk is high because, in comparison, the cost of not removing the risk is higher - the loss of human life.

\section{iii. Is the Loss Suffered Caused by the Conduct of the Defendant?}

To answer this inquiry, what must rather be asked is where would the claimants have been if not in the building at the time in question? Specifically, would they have suffered injury but for the conduct of Bazlus Adnan? As I have mentioned, victims refused to enter Rana Plaza on 24 April because of the crack that appeared the previous day, for which they were ordered to evacuate. ${ }^{63}$ However, Managers forced employees inside the premises and threatened them with dismissal from service if they refused. ${ }^{64}$ Therefore, it can be accepted that if the victims were not inside Rana Plaza, they would have been elsewhere - removed from the vulnerable building. However, to answer whether they would have suffered injury but for the conduct of Adnan will be a lengthier discussion. That is, if the injury would have occurred in the absence of Adnan's conduct, he is not liable.

\footnotetext{
62 Ibid at 306.

${ }^{63}$ Motlagh \& Saha, supra note 54 at 66-68.

64 "Rana Plaza Collapse: Dozens Charged with Murder" The Guardian (1 June 2015), online: Guardian News and Media Limited <https://www.theguardian.com/world/2015/jun/01/rana-plaza-collapse-dozens-charged-with-murderbangladesh $>$ [Guardian: Rana Plaza Collapse].
} 
Those harmed from the collapse of Rana Plaza would not have suffered injuries if not for Sohel Rana's assurance that the building was safe, and Adnan's failure to confirm whether the building was indeed safe. Rana assured Managers and factory owners that the facility was safe "for another hundred years"; ${ }^{65}$ yet, there was no remedy for the danger for which the building was evacuated the previous day. Adnan's duty to his employees to guarantee the safety of the site where they work is high, and therefore, he is not excused from liability simply because Rana assured the building was safe. ${ }^{66}$ Moreover, the duty imposed on Adnan is so high that he is also responsible for making sure that any place his employees use in connection with work is safe, such as access to the building from the street. ${ }^{67}$ Therefore, since Adnan was aware of the facility's vulnerability, he should not have relied on Rana's assurance, but that of the engineer's, who recommended sealing off the site. The question that arises is even if the remaining garment factories were open, why did Adnan not close his factory?

There was a branch of BRAC Bank inside Rana Plaza that also closed on 23 April when they saw the crack. ${ }^{68}$ However, on the day of the collapse, the branch remained closed, as employee safety could not be guaranteed because no remedial measures were taken. Therefore, no employees working at BRAC were injured from its collapse. It is important to note that one

\footnotetext{
${ }^{65}$ Motlagh \& Saha, supra note 54 at 66; See Chapter 1, supra at 10; Since Sohel Rana, the owner of the facility, assured Managers and factory owners that the building was safe "for another hundred years," he may also be found negligent. However, I have not asked whether he was because it would be outside the scope of this Thesis.

${ }^{66}$ Fleming, supra note 3 at 560-562.

${ }^{67}$ A.C.I. Stamping and Spinning Proprietary Limited v Boczulik, [1964] HCA 26, 110 CLR 372.

${ }^{68}$ Fred De Sam Lazaro, "Questions Linger a Year After Bangladesh's Garment Factory Collapse” PBS Newshour (9 April 2014), online: NewsHour Productions LLC <http://www.pbs.org/newshour/updates/questions-linger-afterbangladeshs-garment-factory-collapse/> [Lazaro]; "BRAC" was formerly known as "Bangladesh Rural Advancement Committee," at Fazle Hasan Abed, "Bangladesh Needs Strong Unions, Not Outside Pressure" The New York Times (29 April 2013), online: The New York Times Company <http://www.nytimes.com/2013/04/30/ opinion/bangladesh-needs-strong-unions-not-outside-pressure.html?_r=0>.
} 
employer was cautious and kept business closed because he could not guarantee the safety of his employees, while the other was not. That is, BRAC Bank did not rely on Rana's pronouncement about the safety of the building, but relied on what the engineer had said. Therefore, it was Adnan's decision to continue business even though he could not guarantee the safety of his employees that caused injuries, as injuries would not have happened even if the building collapsed at precisely the same time and day. ${ }^{69}$

\section{iv. Contributory Negligence on the Part of Claimants Barring Recovery}

Individuals who are negligent of their own safety are barred recovery from the defendant. ${ }^{70}$ Contributory negligence is not the plaintiff's negligence contributing to the accident, but that the plaintiff failed to avoid being hurt. ${ }^{71}$ If a claimant's contributory negligence is to count against him, then it must be a cause of the loss suffered by him. ${ }^{72}$ Therefore, if the victims at Rana Plaza failed to avoid being injured from an avoidable accident, then they are contributorily negligent.

\footnotetext{
${ }^{69}$ Briefly, I must also consider the issue of proximate cause. While cause is a question of fact, and therefore, determined without much difficulty, proximate cause, or remoteness, is more difficult, as it seeks to limit liability on the defendant because the damage in question is suffered by a party that was remote or unforeseeable. If I were seeking to determine negligence on the part of Sohel Rana for psychological trauma suffered by a pedestrian that happened to be walking by the site when the building collapsed, I would consider the issue of proximate cause in greater detail. However, since I am concerned with employees inside Rana Plaza, the issue of injury occasioned on a person removed from the site, and thus remote, does not arise; At Linden \& Feldthusen, supra note 25 at 362 \& 377-378; However, in Canada, the issue of the "unforeseeable plaintiff" has garnered criticism as being overly narrow. Thus, Linden \& Feldthusen propose that the question courts ought to ask is "whether the defendant, whose conduct has fallen below the accepted standard of the community, should be relieved from paying for some unusual damage that his conduct helped to bring about," at 378.

${ }^{70}$ Ibid at 493-494; Fleming, supra note 3 at 302-303.

${ }^{71}$ Fleming, ibid at 302; Chamberland v Fleming, [1984] AWLD 832 (where boaters were contributorily negligent for drowning owing to their decision in not wearing life jackets); Hendricks $v R$, [1970] SCR 237 (where boaters were contributorily negligent for failure to sight a waterfall); Lepine v Demeule, [1973] 3 WWR 732 (where a pedestrian was contributorily negligent in walking on the road with his back turned to the direction from where traffic was flowing); Rozenhart v Skier's Sport Shop (Edmonton) Limited, [2004] 9 WWR 527 (where a skater was contributorily negligent for his injuries due to his beginning of skating prior to the instructor's arrival and even when he was told to wait; Crocker v Sundance Northwest Resorts Limited, [1988] 1 SCR 1186 (where the plaintiff was held contributorily negligent for self-induced intoxication and participating in a tube race).
}

${ }^{72}$ Koeppel v Colonial Coach Lines Limited, [1933] 3 DLR 469. 
First, employees at Rana Plaza were sent home from work on 23 April because of the crack on the structure. That is, employees were cognizant of the danger. Second, on 24 April, employees were inside the building when it collapsed, even though they were aware that no measure was implemented to remedy the danger. Therefore, it seems that they were contributorily negligent because they failed to avoid an avoidable accident. However, with the benefit of analysis, it can be seen that their negligence is vitiated on account of the social milieu of workers in Bangladesh.

\section{iv.1 - The Poorest are Working at Garment Factories}

Some of the poorest people in Bangladesh labor in the RMG sector. ${ }^{73}$ As of $2010,76 \%$ of the population lived on less than $\$ 2$ daily, and until January 2015 , a monthly pay of $\$ 38$ was the lowest amount paid to garment employees. ${ }^{74}$ According to Nari Uddug Kendra, a Bangladeshi NGO, to meet the monthly expense of food, a single person requires $\$ 19$, and it costs roughly \$26 to \$39 for taking residence, usually in slums. ${ }^{75}$ Additionally, it has become very common that those laboring at garment factories are the sole breadwinners for their families. ${ }^{76}$ Moreover, the majority of those working in the RMG industry lack formal education. ${ }^{77}$ It is on this

73 "ILO Report Presents a Path to Sustainable Growth in Bangladesh" International Labour Organization (18 November 2013), online: International Labour Organization <http:/www.ilo.org/global/about-the-ilo/newsroom/ news/WCMS_229135/lang--en/index.htm> [ILO: Report].

${ }^{74}$ Ibid. The minimum wage has since been increased to \$68, see note 104, supra at Chapter 2.

${ }^{75}$ Elizabeth Cline, Overdressed: The Shockingly High Cost of Cheap Fashion (New York: Penguin, 2012) at 150-155 [Cline]; Nari Uddug Kendra is commonly referred to in English as "Center for Women's Initiatives."

${ }^{76}$ Ibid; Also see "Bangladesh: Seeking Better Employment Conditions for Better Socioeconomic Outcomes" International Labour Organization (2013), online: International Labour Organization, International Institute for Labour Studies <http://www.ilo.org/wcmsp5/groups/public/---dgreports/---dcomm/documents/publication/ wcms_229105.pdf $>$ at 6-10.

${ }^{77}$ Mehul Srivastava \& Arun Devnath, “Bangladesh's Paradox for Poor Women Workers: Low Wages and Hazardous Conditions Put Workers in Harm's Way” Bloomberg (9 May 2013), online: Bloomberg LP <http:// www.bloomberg.com/news/articles/2013-05-09/bangladeshs-paradox-for-poor-women-workers $>$. 
backdrop against which the contributory negligence of employees at Rana Plaza should be considered. This brief recitation of facts reveals a scenario where what seems like contributory negligence is actually not because of the social circumstances of the workers.

On 24 April, victims, fully apprised of the crack on the structure, congregated in front of Rana Plaza, refusing to enter the premises. Their refusal was grounded on their collective ability to appreciate the risk the crack posed. Therefore, presuming every employee lacks formal education, their illiteracy, which may speak to their capacity to appreciate risk, carries no weight because they were aware of the danger. As in, the building was evacuated on 23 April and the victims refused to enter the building on 24 April, which is evidence that the victims knew of the danger. This begs the question of why employees were inside despite their knowledge of the circumstances?

\section{iv.2 - The Plight of Garment Workers}

Managers threatened employees with dismissal from service if they declined to enter the facility. ${ }^{78}$ This really lies at the heart of the issue when considering why employees were inside the facility even though they knew that the danger continued. Though wages of $\$ 38$ were paid to employees, the salary was consistent. This amount permitted them to secure housing, purchase food, financially support their family, and acquire the daily necessities of life. ${ }^{79}$ When threatened with the termination of employment, it could have incapacitated employees from exercising good judgment. In weighing the factors, the victims would realize that if they refused to enter the facility and begin work, their dismissal was certain. ${ }^{80}$ Thus, while certainty rested in their

\footnotetext{
${ }^{78}$ Guardian: Rana Plaza Collapse, supra note 64.

${ }^{79}$ Cline, supra note 75 at 152.

${ }^{80}$ Guardian: Rana Plaza Collapse, supra note 64.
} 
dismissal from work if they refused to enter the building, the element of uncertainty was 'what would happen to the building'? That is, their decision in refusing to enter guarantees

unemployment; yet, it does not guarantee that they were saving their lives because the building may collapse. In other explanatory terms, one was a guarantee (refusal equals dismissal), while the other was an apprehension (building was weak and may collapse). Therefore, in calculating the risks, that which was certain was weighed more heavily against that which was not.

It is also at this point that the extent of employees' formal education should be taken into consideration. The lack of literacy speaks to their inability to find a job elsewhere if they were dismissed. ${ }^{81}$ The population of Bangladesh is 159.1 million, while $4.3 \%$ of the labor force is currently unemployed, which equates to $6,841,300$ persons. ${ }^{82}$ As in, if a person loses his job, he would be competing for scarce employment opportunities against nearly seven million others. When this is factored into the calculation of what employees may have considered on 24 April, it seems as if they were deprived of a reasonable alternative. Therefore, they were coerced into making a decision that they probably would not have naturally arrived if an alternative existed. What seems like a voluntarily formulated decision to enter the premises is actually involuntary because they were forced into the building and there was no reasonable alternative.

In summation, victims were injured from the collapse of Rana Plaza. The employer, Bazlus Adnan, owed a common law and statutory duty of care to those injured. While he was cautious and ordered the evacuation of the facility on 23 April, he did not operate with the same

\footnotetext{
${ }^{81}$ See generally Phillip Brown \& Hugh Lauder, "Education, Globalization and Economic Development” (1996) $11 \mathrm{~J}$ Education Pol'y 1.

82 "Bangladesh" The World Bank (2016), online: The World Bank Group: IBRD. IDA < http://www.worldbank.org/ en/country/bangladesh>; For unemployment percentage, see "Unemployment, Total (\% of Labor Force)" The World Bank (2016), online: The World Bank Group: IBRD, IDA <http://data.worldbank.org/indicator/SL.UEM.TOTL.ZS > [World Bank: Unemployment].
} 
level of caution the following day. As a result, his employees were injured because of his failure to prohibit them from entering the premises, marking a breach in the standard of care. As the employer, since Adnan owes a high duty of care to his employees, and since the victims would not have been inside had it not been for Adnan's failure to confirm that the building was safe, it can be held that they suffered injuries because of Adnan's omission. Due to employees being coerced into entering New Wave, they are not contributorily negligent. Therefore, Adnan was negligent in his duties as employer, and since I have established that he failed to ensure the safety of his employees, I will now turn to whether Rana Plaza and LCL were involved in one economic enterprise.

\section{D - IS LOBLAW \& RANA PLAZA INVOLVED IN ONE ECONOMIC ENTERPRISE?}

I am of the opinion that establishing negligence on the part of Adnan was the easy task. The more difficult undertaking, which I will now embark upon, involves exploring the complex legal relationship between LCL and Rana Plaza. Therefore, while I demonstrate that Rana Plaza was involved in the same economic enterprise as LCL, I will untangle two complicated issues. First, LCL's knowledge of Rana Plaza's work transforms Rana Plaza from a subcontractor to that of a contractor; and second, the consistent contact between LCL and Rana Plaza, in addition to Adnan's dependency on LCL's business, makes LCL his employer. On these grounds, I then recommend that LCL should be held vicariously liable because it was the introducer of a risk that ultimately ripened into harm.

To reveal that the relationship between LCL and Rana Plaza was that of a contract of service, firstly, the two questions that need to be examined are whether Adnan provided equipment necessary for garment production and whether he hired his own helpers or workers. 
The answer to both questions is 'yes, he did.' Beginning from the fabric to the machinery necessary in garment production, they are provided by Adnan, and he also hires persons necessary for the task. ${ }^{83}$ Secondly, Adnan's chance for profit from the services he provided LCL was exorbitant. He was earning \$15 million annually, "[T]hanks in large part to [LCL]" who was his biggest client and from whom he earned $\$ 6$ million ${ }^{84}$ Therefore, the brief consideration of these three questions indicates a contract for service relationship. However, only upon exploring LCL's level of knowledge and the degree of control it exercised over Rana Plaza will the true nature of the relationship between the two parties emerge.

\section{i. Level of Knowledge \& the Protective Shield of Subcontracting}

LCL was careful in legally removing itself from maintaining contact with Rana Plaza that may possibly give rise to litigation. That is, Rana Plaza was a subcontractor, as LCL placed orders to produce garments with PGI, a company in India, who then forwarded the order to Rana Plaza ${ }^{85}$ Thus, it seems that LCL has managed to insulate itself from liability on account of its separation from Rana Plaza, and as is often the case, manufacturers remain unaware of the subcontract. Therefore, if the manufacturer is unaware that their contractor subcontracted the original contract, the law does not hold him liable. ${ }^{86}$ However, as Patrick Atiyah declares the view held by courts is that "the employer will be liable for the acts of a subcontractor where he knows or ought reasonably to know that the contractor is likely to subcontract." ${ }^{87}$ Thus, if I can

\footnotetext{
${ }^{83}$ Alexander, supra note 61 at 304-305; Interview with Adnan, supra note 53.

${ }^{84}$ Interview with Adnan, ibid; Tarannum Kamlani, "Made in Bangladesh" CBC The Fifth Estate (11 October 2013), online: CBC/Radio-Canada <http:/www.cbc.ca/fifth/episodes/2013-2014/made-in-bangladesh> [Kamlani].

${ }^{85}$ Kamlani, ibid; Also see Chapter 1, supra at 8-9.

${ }^{86}$ Atiyah, supra note 4 at 341-345.

${ }^{87}$ Ibid at 346; Also see Walsh v Holst \& Co Limited and Others, [1958] 3 All ER 33.
} 
prove that LCL knew or should reasonably have known that PGI subcontracted Rana Plaza,

LCL's shield of liability can be pierced.

\section{ii. How Bureau Veritas Pierces the Shield of Liability as Set by the Subcontract}

Bureau Veritas is a "global leader in [t]esting, [i]nspection and [c]ertification" that helps

clients deal with issues of "quality, safety, environmental protection and social responsibility." 88

LCL enlisted the services of Veritas to conduct annual inspections of its supplier factories.

Surprisingly, the inspected factory was not PGI, the original contractor, but was Rana Plaza. ${ }^{89}$

This is astonishing because not only does it prove that LCL knew that Rana Plaza was

fabricating its garments, but also because it shows LCL's deliberate decision of examining Rana

Plaza. As in, Veritas did not voluntarily inspect Rana Plaza, but only did so when LCL

commissioned its services to inspect the facility.

Moreover, Galen Weston, Executive Chairman of LCL, has admitted to viewing reports

from Veritas on Rana Plaza. However, the reports "do [not] cover structural integrity." 90

Regardless of what the inspection covered, conscripting Veritas to inspect Rana Plaza, and not

PGI, is evidence that LCL knew that Rana Plaza was its supplier even though the facility was subcontracted.

If this is insufficient to demonstrate that LCL knew that Rana Plaza was its supplier, then what is truly astonishing is that LCL had also sent its own employees biannually to the 47

\footnotetext{
88 "Profile" Bureau Veritas (2016), online: Bureau Veritas Group <http://www.bureauveritas.com/home/about-us>; For general site, see $<$ http://www.bureauveritas.com $>$.

${ }^{89}$ Francine Kopun, “Bangladesh Factory Collapse: Loblaw to Audit Structural Safety of Suppliers' Buildings” The Star (2 May 2013), online: Toronto Star Newspapers Limited <https://www.thestar.com/business/2013/05/02/ bangladesh_factory_collapse_unions_put_pressure_on_loblaw_joe_fresh.html>.

${ }^{90}$ Mark Mackinnon \& Marina Strauss, "Spinning Tragedy: The True Cost of a T-Shirt" The Globe and Mail (12 October 2013), online: The Globe and Mail Incorporated <http://www.theglobeandmail.com/report-on-business/ spinning-tragedy-the-true-cost-of-a-t-shirt/article14849193/?page=all $>$.
} 
supplier factories in Bangladesh, including Rana Plaza, to "check them out." 91 Furthermore, LCL has said, "[W]e, and our third party audit firms, visited our vendor factories located inside Rana Plaza." 92 Therefore, LCL knew that PGI subcontracted Rana Plaza and knew that the latter was fabricating its garments. As a result, LCL cannot deny, unless by miraculous contrary facts, that it did not know what work Rana Plaza was doing.

Since I have established knowledge on the part of LCL regarding its relationship to Rana Plaza, I will now turn to the more complex step of demonstrating an employment relationship between the two parties. Otherwise LCL cannot be held liable for Adnan's negligence. LCL can no longer hide behind the subcontract, as I have demonstrated its knowledge that it knew of the subcontract.93 Overall, LCL's knowledge of Rana Plaza serving as its supplier, and the degree of control it exercised over Adnan will demonstrate that Rana Plaza and LCL became part of one economic enterprise.

\section{iii. Contract of Service}

The design, quantity, and the delivery date are set by the manufacturer, who then sends a Letter of Credit to the factory owner's (Adnan) bank stipulating that he will receive payment only upon delivery. ${ }^{94}$ Factory owners procure materials necessary for production, fabricate garments, and pay their employees for their labor. ${ }^{95}$ Once the garments are fully made, they are

\footnotetext{
${ }^{91}$ Marina Strauss, "Loblaw Calls on Industry to end 'Unacceptable Risk' in Bangladesh” The Globe and Mail (2 May 2013), online: The Globe and Mail Incorporated <http://www.theglobeandmail.com/report-on-business/loblawcalls-on-industry-to-end-unacceptable-risk-in-bangladesh/article11676189/> [Strauss: Unacceptable Risk].

92 Kamlani, supra note 84.

${ }^{93}$ Atiyah, supra note 4 at 346.

${ }^{94}$ Alexander, supra note 61 at 304; Also see Laura Ho, Catherine Powell \& Leti Volpp, "(Dis)assembling Rights of Women Workers Along the Global Assembly Line: Human Rights and the Garment Industry" (1996) 31 Harv CRCLL Rev 383 at 385-386.

${ }^{95}$ Ibid at 305.
} 
affixed with the correct brand name (price inflated), wrapped in plastic bags, placed in boxes, and transported to Chittagong, a city five hours from Dhaka. In Chittagong, the boxes of garments are loaded onto a ship and transported to the manufacturer. ${ }^{96}$ It is at this point that the owner submits appropriate documentation, usually the shipment confirmation, to his bank and requests payment from the manufacturer, which often takes up to six months to process.

If merchandise is not delivered timely, owners are left with no alternative but to send the goods by air, for which the owner bears the high cost of transportation. ${ }^{97}$ To avoid this cost, owners are keen, often overambitious, to have merchandise delivered timely. It is this pressure that became a critical factor as to why employees were inside Rana Plaza when it collapsed. It is also this element that tips the scale in favor of viewing the relationship between LCL and Rana Plaza as that of a contract of service, as explained below.

\section{iv. Degree of Control \& the Commonality of Enterprise}

At the time of the collapse, New Wave was amid fabricating 24,000 pairs of shorts for LCL, and the deadline for shipment was approaching. ${ }^{98}$ Adnan has said, "[Loblaw] squeezed me" continuously to "ship [merchandise] on time." 99 This point is luminous because, first, it displays the communication that happened between LCL and Adnan; and second, LCL was able to exert this pressure only because New Wave was part of its supply chain, indicating a relationship of one economic enterprise. Not only did LCL and Veritas inspect Rana Plaza, its contact with

\footnotetext{
${ }^{96}$ Ibid at 305-306; See Chapter 2, supra at 31-32.

97 Ibid at 306.

${ }^{98}$ Michelle Chen, “A Western Company Could Finally Be Held Accountable for the Rana Plaza Disaster” The Nation (29 April 2016), online: The Nation Company <https:/www.thenation.com/article/a-western-companycould-finally-be-held-accountable-for-the-rana-plaza-disaster/> [Chen].

${ }^{99}$ Interview with Adnan, supra note 53.
} 
Adnan did not end at inspection. Rather, because LCL needed the merchandise timely, they maintained consistent contact with Adnan to ensure delivery would not be delayed.

It is also this pressure and the consistency in communication between LCL and Adnan that required victims to work from 8:00 am to $8: 00 \mathrm{pm}$ daily to complete LCL's order. It was in Adnan's best interest to have merchandise delivered timely so that he can look forward to repeat business, and not lose a client from whom he annually earned $\$ 6$ million. ${ }^{100}$ Since LCL was Adnan's biggest client, he did not wish to disappoint the company by not being able to deliver merchandise within the timeframe. While he may not have wanted to incur the higher cost of transporting the goods by air, a more pragmatic view is that a manufacturer can find a different supplier that could deliver goods in a timelier fashion with the same cost simply because of a higher capacity of production.

\section{iv.1 - An Employment Relationship without a Formal Employment Relationship?}

Since business relationships are constantly changing, courts have recognized that there could exist an employment relationship without a formal agreement between the employee and employer. The deciding factor is the 'dependency and potential control' between the parties. In the words of Lord Justice Alan Ward, "[T]he question of control should be viewed in a wider sense than merely inquiring whether the employer has the legal power to control how the employee carries out his work."101 Thus, I will demonstrate that even though there was no formal employment agreement between LCL and Adnan, one nonetheless existed on account of the potential control LCL had over the activities of New Wave.

\footnotetext{
100 Ibid; Donald Waters, Supply Chain Management: An Introduction to Logistics, 2d ed (New York: Palgrave Macmillan, 2009) at 38 [Waters].

101 JGE v English Province of Our Lady of Charity, [2012] EWCA Civ 938 at para 76; Also see Peter Rott \& Vibe Ulfbeck, "Supply Chain Liability of Multinational Corporations?" (2015) 23 ERPL 415 at 425.
} 


\section{iv.2 - Loblaw Had the Option of Selecting Another Supplier}

As I have covered in Chapter 2, it is not a secret that Bangladesh offers inexpensive labor. Around 2005, when China's labor costs began escalating, LCL, in search of higher profit margins from cheaper labor, slowly shifted production to Bangladesh. ${ }^{102}$ From 2007, Adnan began producing garments for LCL. ${ }^{103}$ As of 2013, there were 5,876 garment factories in Bangladesh, and if LCL were disappointed with Adnan, they could have relocated production to any one of them, causing Adnan to lose valuable business. ${ }^{104}$ While the reason as to why LCL moved production from China to Bangladesh (cheaper labor) is not the same as to why LCL could find a different supplier (timely delivery), what must be understood is that if LCL wanted, they had the option of moving to a different supplier and still maintain the same profit margins. Therefore, had LCL chosen a different supplier, its $\$ 45.39$ billion business, ${ }^{105}$ of which garments constitutes $\$ 7.41$ billion, ${ }^{106}$ would be unaffected, while Adnan would lose $\$ 6$ million in annual income.

There remains little doubt that in the globalized economy competition between businesses has become more fierce, which adds pressure on any member of the supply chain, and

\footnotetext{
102 Chen, supra note 98; See Chapter 2, supra at 36-40 \& 43-45.

103 Interview with Adnan, supra note 53.

104 "Trade Information: Membership and Employment" Bangladesh Garment Manufacturers and Exporters Association (22 February 2016), online: Bangladesh Garment Manufacturers and Exporters Association: Towards a Sustainable Garments Industry $<$ http://www.bgmea.com.bd/home/pages/tradeinformation $>$. This number has since lessened to 4,296 as of 2015 .

105 I have retrieved LCL's 2015 Financial Review Report from the System for Electronic Document Analysis and Retrieval website, whose homepage can be accessed here $<$ http://www.sedar.com/homepage_en.htm $>$. Once accessed, click "Search," then "Search for Company Documents" and type in 'Loblaw' under the "Company Name" search bar.

106 Linda Nguyen, "Loblaw Goes Global with Joe Fresh Stores” Global News (20 February 2014), online: Global News <http:/globalnews.ca/news/1161347/loblaw-goes-global-with-joe-fresh-stores/>.
} 
if one member fails in its promise, the entire process is frustrated. ${ }^{107}$ The constant reminder to deliver merchandise timely transforms LCL from being 'just a buyer' to an employing powerhouse that can relieve the supplier of its duties and take that business elsewhere. ${ }^{108}$ This creates an apprehension in the mind of the supplier, who is highly, if not completely, dependent on the business of the manufacturer. Furthermore, it is evidence of potential control over the activities of New Wave, as identified in English Province. Thus, while Adnan may have originally been in business on his own account, the consistent contact with LCL and the dependency on LCL's business transformed the latter into an employer. Due to the volume of LCL's revenue, Adnan would not want to lose its business. Therefore, since Adnan's remuneration was completely dependent upon successfully completing LCL's orders, he would not want to disappoint LCL to such an extent that it finds another supplier. ${ }^{109}$

\section{iv.3 - Importing the Hudbay Guidelines}

It is at this point where the factors outlined in Hudbay should be imported to further demonstrate an enterprise relationship between LCL and Rana Plaza. I will consolidate the two factors of whether employees from LCL were in charge of operations at New Wave and whether LCL controlled New Wave. ${ }^{110}$ Firstly, employees from LCL were not in charge of operations at New Wave. However, and this is my second point, LCL's consistent contact with New Wave to have goods delivered timely indicates a degree of control whereby Adnan's authority is

\footnotetext{
${ }^{107}$ Waters, supra note 100 at 50-51.

${ }^{108}$ Ibid at 51; Also see Chapter 2, supra at 45-48.

${ }^{109}$ Alexander, supra note 61 at 305-307.

${ }^{110}$ I once again add that I am fully aware that Rana Plaza is not a subsidiary of LCL. I import the Hudbay decision to illustrate that even though Rana Plaza was not a subsidiary of LCL, the relationship between the two still meets the criteria of demonstrating a lack of a separate legal personality. As in, it is evidence of one corporation or, in the case of Rana Plaza, one economic enterprise.
} 
somewhat diminished as he is completely guided, directed, and dominated by LCL. ${ }^{111}$ That is, while LCL does not direct the means of production, its constant reminder of delivering goods timely has an overarching impact on Adnan. LCL's influence then became so pervasive that despite a sign of vulnerability in Rana Plaza, Adnan's decision did not consider the safety of the victims, but the end result of satisfying his employer — LCL.

\section{iv.4 - Work at New Wave was Integral to Loblaw}

What must also be factored into the equation is that the work of New Wave was not accessory to LCL, but was integral to its business. ${ }^{112}$ This is critical because merchandise must first be produced in order to sell it to generate revenue. For example, the fabrication of garments is different from the transportation of garments. Though transporting garments is also important because otherwise LCL would not be able to sell the goods in Canada, what is more important is that nothing would be transported if products were not first fabricated. Thus, what New Wave did for LCL was the essential task of producing goods; that is, it furnished LCL with the products that was fundamental to the corporation's ability to generate profit. ${ }^{113}$

The work of New Wave greatly benefitted LCL. If New Wave did not provide garments, LCL would have lost revenue, though minimal in comparison to Adnan. Therefore, New Wave, though subcontracted and unowned by LCL, was a crucial component of LCL's supply chain so much so that it naturally becomes, or ought to be considered, as part of the same enterprise as LCL. ${ }^{114}$ As a result, because the work of New Wave was so integral to LCL, the latter

\footnotetext{
111 Choc v Hudbay Minerals Inc, [2013] OJ No 3375, paras 45-46, 2013 ONSC 1414 [Hudbay].

112 Stevenson, Jordan \& Harrison Limited v MacDonald \& Evans, [1952] 1 TLR 101.

113 Christopher Stone, "The Place of Enterprise Liability in the Control of Corporate Conduct" (1980) 90 Yale LJ 1 at $8-9$.

114 Adolf Berle Jr., “The Theory of Enterprise Entity” (1947) 47 Colum L Rev 343 at 343-346 [Berle].
} 
consistently contacted the former to ensure it receives its orders timely, and was able to exert pressure on Adnan to that end. This is evidence of one economic enterprise that is only separated by a geographical distance.

\section{iv.5 - Loblaw's Profits Derived from the Labor of New Wave}

While the enactment of the Workmen's Compensation Act 1897 in the United Kingdom owes credit to enterprise theory, ${ }^{115}$ which seemed radical at the time, it would be ill advised to not consider Rana Plaza as part of the economic enterprise of LCL. Together, Rana Plaza and LCL formed a "unity of life" where they both worked towards a common goal — profit.116 As in, while Adnan sought profit for himself while doing the work for LCL, his work ultimately yielded tremendous profits for the latter company. Therefore, it was LCL who would gain the most profit from the labor of the victims inside New Wave. ${ }^{117}$

Additionally, Adnan would not have profited from his business but for LCL's contract, which indicates the merger of their original separate activities. ${ }^{118}$ That is, both LCL and Adnan depended on the other so that each party can profit from the business they were undertaking. To further clarify, one party could not profit without the other. Thus, even though Rana Plaza is not a subsidiary of LCL, its work was carried out for the benefit of LCL, and because LCL maintained consistent contact with Adnan, the overall relationship between the two parties should be considered as being part of the same economic enterprise. ${ }^{119}$

\footnotetext{
115 Brodie, supra note 2 at 3.

116 Maurice Dix, “The Economic Entity” (1953) 22 Fordham L Rev 254 at 255 [Dix]; Jonathan Landers, “A Unified Approach to Parent, Subsidiary, and Affiliate Questions in Bankruptcy” (1975) 42 U Chicago L Rev 589 at 591.

${ }^{117}$ Kurt Strasser, "Piercing the Veil in Corporate Groups" (2004-2005) 37 Conn L Rev 637 at 638-639.

118 Dix, supra note 117.

${ }^{119}$ Berle, supra note 114.
} 
To summarize, LCL was fully aware that Rana Plaza was fabricating its garments, as it otherwise would not have inspected, or hired Veritas to inspect the facility. LCL, through consistent contact, exercised a degree of control over Adnan to an extent where the latter's authority over the activities of the victims were overwhelmingly dominated by LCL. ${ }^{120}$ As in, because of the inequality in bargaining power between Adnan and LCL, when LCL demanded merchandise within a timeframe, Adnan acquiesced in fear that the company may find another supplier who can meet its demands — indicating Adnan's diminished control. Since the work of New Wave was integral to LCL, and because LCL profited from the work of New Wave, the relationship between New Wave and LCL is characteristic of one economic enterprise.

\section{v. Creation and Exacerbation of Risk}

As Justice McLachlin states, the employer should only be liable for risks he has "created or exacerbated"; otherwise, he would turn into an involuntary insurer. ${ }^{121}$ Thus, the first question that needs to be answered is whether LCL created the risk; that is, was Adnan in business before LCL conscripted his services? This question invites an ambivalent response. First, Adnan was in business even before LCL first contacted him, as he was fabricating garments for other companies. ${ }^{122}$ Secondly, the ninth floor of Rana Plaza was being constructed for Adnan because he was expanding his business to meet LCL's higher demands. ${ }^{123}$ Therefore, while LCL may not have originally created the risk, they certainly helped and contributed to its continuation, as Adnan would otherwise not require an additional floor be constructed. Additionally, of the six

\footnotetext{
${ }^{120}$ Hudbay, supra note 111.

${ }^{121}$ Bazley, supra note 5 at para 37; Also see Brodie, supra note 2 at 3-10.

122 Interview with Adnan, supra note 53.

${ }^{123}$ Ibid; See Appendix A, infra at 156.
} 
garment factories inside Rana Plaza, Adnan owned three of them, of which two were fabricating garments for LCL. ${ }^{124}$

Third and most importantly, even if LCL did not create the risk, it definitely exacerbated it by consistently contacting Adnan to have merchandise readied and delivered timely. The aim of LCL, the profit driven corporation, is obtaining profit from the sale of merchandise that was being produced at New Wave. ${ }^{125}$ The world of fashion entails constant evolution and offering customers a wide selection of garments. ${ }^{126}$ That is, if LCL received their merchandise late, it would be delayed in introducing those items to customers in stores, and would lose valuable time in competition, whereas others will have already launched similar products. ${ }^{127}$ Therefore, LCL required their merchandise made and delivered within a time limit from which Adnan could not depart. If Adnan was not pressured by LCL regarding the deadline, maybe he would have been more cautious and would not have allowed victims to enter Rana Plaza on 24 April.

\section{v.1 - If BRAC were Closed, Why was New Wave Not?}

I also add emphasis to the point that BRAC Bank remained closed on 24 April, whereas New Wave was open. ${ }^{128}$ BRAC's profits did not stem from fabricating and exporting garments; therefore, unlike Adnan, they were not guided by an MNE's delivery deadline. ${ }^{129}$ As in, BRAC faced no pressure from a multinational enterprise to deliver merchandise and was not rushing to

\footnotetext{
124 Motlagh \& Saha, supra note 54 at 67; See Appendix A, infra at 156.

125 See Milton Friedman, Capitalism and Freedom (Chicago: University of Chicago Press, 2002) at 133; See Chapter 2, supra at 32-35 and 45-48.

${ }^{126}$ Gérard Cachon \& Robert Swinney, "The Value of Fast Fashion: Quick Response, Enhanced Design, and Strategic Consumer Behavior” (2011) 57 Management Science 778 at 778-779 [Cachon]; Cline, supra note 76 at 5-27. 
complete an order. Therefore, BRAC could act in a careful manner and guarantee the safety of its employees. Furthermore, BRAC's business did not depend on LCL.

Alternatively, for Adnan, because he was directed by the consistent contact with LCL, and since his business was dependent on providing LCL with garments, he did not operate with the same level of caution as did BRAC. Therefore, what can be said is that if Adnan were not fabricating garments for LCL, no risk would have been exacerbated by LCL's consistent contact because he also would have remained careful. However, because LCL consistently contacted New Wave, it can be held that it exacerbated the risk. Furthermore, this exacerbation persisted because of the control — whether actual or potential — LCL had over New Wave.

\section{v.2 - Worldwide Responsible Accredited Production}

While LCL inspected Rana Plaza and also commissioned Veritas to do so, it should have known of the Worldwide Responsible Accredited Production (hereinafter "WRAP”). WRAP is an "independent, objective nonprofit team of global social compliance experts [...] promoting safe, lawful, humane and ethical manufacturing around the world through certification and education." 130 On the day of the collapse, Russell Jowell, the Communications Manager at WRAP, announced how New Wave was certified by WRAP, but that the certification expired on

October 2012. The certificate expired because New Wave was not compliant with WRAP's 12 Principles, particularly on grounds of health and safety regarding means of egress and overcrowding. ${ }^{131}$

\footnotetext{
130 “About WRAP” Worldwide Responsible Accredited Production (2016), online: WRAP < http:// www.wrapcompliance.org $>$.

${ }^{131}$ Russell Jowell, "Statement Regarding the Collapse of the Rana Plaza Building in Bangladesh" Worldwide Responsible Accredited Production (24 April 2013), online: WRAP < http://www.wrapcompliance.org/documents/ news/WRAP_Rana_Plaza_Statement.html>; For WRAP's 12 Principles, see "WRAP's 12 Principles" Worldwide Responsible Accredit Production (2016), online: WRAP <http://www.wrapcompliance.org/en/12-principles>.
} 
Avedis Seferian, Chief Executive Officer at WRAP, has said, "Most buyers will see the audit reports." 132 Therefore, it cannot logically be accepted that LCL did not know that WRAP cancelled New Wave's certificate. While the caveat may be that LCL did not know of the cancellation because WRAP is an independent institution and not tied to LCL, it is offset by LCL's own inspection of New Wave. That is, if WRAP cancelled New Wave's certificate because of health and safety concerns, it would be illogical to conclude that LCL did not know of similar risks because it had also inspected and hired Veritas to inspect Rana Plaza.

Furthermore, Kevin Thomas, Director of Shareholder Engagement at Shareholder Association for Research \& Education, has said LCL "did know of these risks in advance."133 This is extremely important because it shows LCL's knowledge of the risks and condoning its perpetuation. Therefore, as I have said above, even if LCL did not introduce a risk into the community, it certainly exacerbated it by continuously placing orders with the factory, even when it knew of the risks Rana Plaza posed. As a result, it can be accepted that in the absence of LCL's enterprise, the risk would not have continued and people would not have been injured.

\section{v.3 - Was the Risk Inherent in the Enterprise?}

Generally, unlike mining, garment production is not held to inherently possess risks. ${ }^{134}$

However, in the case of Bangladesh, the litany of factory fires and collapses signals a different

\footnotetext{
${ }^{132}$ Marina Strauss, "Loblaw Moves to Improve Safety at Bangladeshi Factories" The Globe and Mail (26 April 2013), online: The Globe and Mail Incorporated $<\mathrm{http}: / /$ www.theglobeandmail.com/report-on-business/loblawmoves-to-improve-safety-at-bangladeshi-factories/article11563889/>; Also see Ariane Lafarrière, After Rana Plaza: Women's Labour Rights in the Bangladesh Garment Export Industry (LL.M. Thesis, McGill University Faculty of Law, 2015) at 69-70 [unpublished].

133 “Loblaw Will ‘Vigorously Defend' Lawsuit Over Rana Plaza Factory Collapse” CBC News (30 April 2015), online: CBC/Radio-Canada $<$ http://www.cbc.ca/news/business/loblaw-will-vigorously-defend-lawsuit-over-ranaplaza-factory-collapse-1.3055872>; For Kevin Thomas' role at SHARE, see “Team" Shareholder Association for Research \& Education (2016), online: SHARE <http://share.ca/about/team/kevin-thomas/\#>.
}

${ }^{134}$ See generally Ladislav Tomášek et al, "Patterns of Lung Cancer Mortality Among Uranium Miners in West Bohemia with Varying Rates of Exposure to Radon and its Progeny" (1994) 137 Radiation Research 251. 
story. Bangladesh has eight Export Processing Zones, which are economic enclaves where goods are imported, manufactured, and then exported with reduced duties, ${ }^{135}$ that have been set up by the GOB to attract foreign investment. ${ }^{136}$ While EPZs forbid the formation of labor unions, they honor the $B L A$ and pay employees substantially higher wages than a factory located outside its boundaries. ${ }^{137}$ For example, while an employee at New Wave was earning \$38, a person employed by a factory inside an EPZ would be earning $\$ 48,{ }^{138}$ which has risen to $\$ 73$ as of 2013. ${ }^{139}$ More importantly, no factory has collapsed inside any of the eight EPZs heretofore. ${ }^{140}$ LCL knew that Rana Plaza was not situated in such an enclave, as it is not a listed factory, and if LCL had garments fabricated at an EPZ, the information would be publicly available. ${ }^{141}$ Herein lies the risk as LCL should have known that factories have not collapsed inside an EPZ, which can be accepted as a safer zone of employment. Rather, they have occurred in places outside EPZs, which is where LCL was having garments fabricated. Therefore, though the 135 “Export Processing Zones” The World Bank (December 1998), online: The World Bank Group: IBRD. IDA $<$ http://www1.worldbank.org/prem/PREMNotes/premnote11.pdf >

136 “About Us” Bangladesh Export Processing Zones Authority (15 February 2015), online: BEPZA < http:// www.epzbangladesh.org.bd/pages/details/about>; See Chapter 2, supra at 37-38.

${ }^{137}$ Lisa Clay, "The Effectiveness of the Worker Rights Provisions of the Generalized System of Preferences: The Bangladesh Case Study" (2001) 11 Transnat'l \& Contemp Probs 175 at 186.

138 "New Pay Structure for EPZ Workers Approved" The Daily Star (26 December 2013), online: The Daily Star $<$ http://www.thedailystar.net/new-pay-structure-for-epz-workers-approved-3987>.

139 Malte Luebker, "Minimum Wages in the Global Garment Industry" International Labour Organization Regional Economic and Social Analysis Unit: Research Note (November 2014), online: International Labour Organization $<$ http://www.ilo.org/wcmsp5/groups/public/---asia/---ro-bangkok/documents/publication/wcms_317002.pdf>.

140 See note 64, supra at Chapter 1.

141 “Investor Report” for all EPZs: Adamjee EPZ < http://epzbangladesh.org.bd/investors/investor_report/adamjeeexport-processing-zone-2>; Chittagong EPZ <http://epzbangladesh.org.bd/investors/investor_report/chittagongexport-processing-zone-2>; Comilla EPZ < http://epzbangladesh.org.bd/investors/investor_report/comilla-exportprocessing-zone $>$; Dhaka EPZ < http://epzbangladesh.org.bd/investors/investor_report/dhaka-export-processingzone-2>; Ishwardi EPZ <http://epzbangladesh.org.bd/investors/investor_report/ishwardi-export-processing-zone>; Karnaphuli EPZ <http://epzbangladesh.org.bd/investors/investor_report/karnaphuli-export-processing-zone-2>; Mongla EPZ < http://epzbangladesh.org.bd/investors/investor_report/mongla-export-processing-zone>; Uttara EPZ $<$ http://epzbangladesh.org.bd/investors/investor_report/uttara-export-processing-zone-2>. 
fabrication of garments is not inherently risky, by engaging Adnan's factory, which was outside such an economic enclave, LCL's enterprise became inherently risky in the context of Bangladesh. Thus, LCL exacerbated a risk that they could have avoided if they chose a factory that was located inside an EPZ.

vi. Negligence Part of Scope of Employment?

After the collapse of Rana Plaza, Galen Weston has said, "I am troubled by a sequence of events, or management practices that saw fit to send apparel workers back into this building after it was declared dangerous." ${ }^{142}$ Therefore, it would be improbable to hold that LCL would have allowed victims to enter the premises on 24 April. However, the concern is not whether LCL would have prohibited entrance into the building on 24 April, but that it authorized New Wave to fabricate garments in the first place. This permitted Adnan to act negligently, thus, marking the unauthorized act. Though Adnan's act of continuing production on 24 April would have been unauthorized by LCL, since it is connected to an authorized act, it is considered a mode of doing what has been authorized by LCL. As in, the very act of fabricating garments is what New Wave was conscripted to do and what the victims were doing when they suffered injuries. Therefore, Adnan's negligence clearly took place during the scope of employment, and as such, his employer — LCL — can be held vicariously liable. ${ }^{143}$

\section{E - POLICY RATIONALES OF HOLDING LOBLAW VICARIOUSLY LIABLE}

Since I have demonstrated that Rana Plaza and LCL were part of the same economic enterprise, Adnan was employed by LCL, and that Adnan's negligence occurred during the scope

\footnotetext{
142 Strauss: Unacceptable Risk, supra note 91.

143 See generally Kay v ITW Limited, [1967] 3 All ER 22; Also see Bazley, supra note 5 at para 18; Refer to note 3 supra because vicarious liability is a form of strict liability. Thus, any misconduct on the part of the employee is automatically imputed on the employer so long as the employee's conduct fell within the "scope of employment."
} 
of employment, I will now discuss the policy rationales of holding LCL vicariously liable. By exploring vicarious liability's policy justifications I will be able to better reveal why LCL should be held liable for the collapse of Rana Plaza.

\section{i. Just \& Practical Remedy}

One of the rationales of vicarious liability is a just and practical remedy for the victims by offering compensation from a solvent defendant. ${ }^{144}$ Since the employer introduced an enterprise and sought to profit from its activities, it is just that he bears the loss resulting from the conduct of his employees. ${ }^{145}$ Surprisingly, those injured from the collapse of Rana Plaza have not received any compensation from Adnan. ${ }^{146}$ Rather, compensation has been distributed through the RPCC. While Adnan can be accepted as solvent, since he was earning \$15 million annually, and therefore has the ability to compensate victims, it is a small amount in comparison to LCL's \$45.39 billion that it earned in $2015 . .^{147}$ This is not to suggest that just because LCL's earnings are disproportionately higher than Adnan that LCL should be held vicariously liable. In fact, it is because LCL is the corporation that introduced an enterprise, exacerbated a risk, and since it sought to profit the most from that enterprise and conscripted workers to that end, it should be held vicariously liable.

As I have demonstrated in this Chapter, Rana Plaza is part of the same economic enterprise as LCL with a "unity of life." What is interesting to note is that when such accidents

\footnotetext{
${ }^{144}$ Mullany \& Linden, supra note 18 at 224; Fleming, supra note 2 at 410; Bazley, supra note 4 at para 30.

${ }^{145}$ Keeton et al, supra note 10 at 500; William Douglas, "Vicarious Liability and Administration of Risk" (1929) 38 Yale LJ 584 at 586.

146 Jason Burke, "Bangladesh Garment Workers Suffer Poor Conditions Two Years After Reform Vows" The Guardian (22 April 2015), online: Guardian News and Media Limited $<$ https://www.theguardian.com/world/2015/ apr/22/garment-workers-in-bangladesh-still-suffering-two-years-after-factory-collapse> .

${ }^{147}$ See note 105 , supra.
} 
occur in a multinational corporation's supply chain, people blame the focal firm. ${ }^{148}$ As in, because of what happened at Rana Plaza, LCL would be blamed, which is why they were quick to sign the Accord and initiate the RPCC, so that its public image is not tainted, because an ill reputation is detrimental to the corporation's profits. ${ }^{149}$ Additionally, in Chapter 2, I had explained the process of branding and how the price of garments fabricated in Bangladesh is inflated once it is affixed with a brand name. Here, I add that Adnan has said LCL was paying him $\$ 15$ to $\$ 16$ for a dozen shorts, ${ }^{150}$ while those shorts were being sold in Canada for at least $\$ 29 .{ }^{151}$ As in, while Adnan was receiving roughly $\$ 1.33$ per pair of shorts, and since it costs $\$ 1$ to ship one article of clothing, ${ }^{152}$ LCL was earning slightly over $\$ 26$ for every pair sold. It is not a surprise that LCL is the largest profiteer from the work of Rana Plaza. However, it must be seen that Adnan would not have been in business but for LCL, and as such, they were part of the same economic enterprise.

Due to globalization, territorial boundaries are regularly transcended for the unity of business. Thus, what was impossible fifty years ago because of difficulty in transportation and communication, has not only become possible today, but has become easy and manageable that

\footnotetext{
148 Julia Hartmann \& Sabine Moeller, "Chain Liability in Multitier Supply Chains? Responsibility Attributions for Unsustainable Supplier Behavior” (2014) 23 J Operations Management 281 at 281-283.

149 Peter Muchlinski, “Human Rights and Multinationals: Is there a Problem?” (2001) 77 Royal Institute Int'l Affairs 31 at 45 .

${ }^{150}$ Interview with Adnan, supra note 53.

151 "Pants and Shorts" Joe Fresh (2016), online: Loblaws Incorporated <https:/www.joefresh.com/ca/Categories/ Men/Pants-Shorts/c/20017>; Since fashion revolves around seasons, shorts will no longer be available on their website during colder months. Therefore, I recommend accessing their homepage and sifting through other products to formulate an approximate estimation of garment prices $<$ https://www.joefresh.com/ca/ $>$.

152 "Benchmarking the Competitiveness of Nicaragua's Apparel Industry" O'Rourke Group Partners LLC (April 2011), online: O’Rourke Group Partners $<$ http://tradebridgeconsultants.com/documents/Nicaragua-Benchmarkingthe-competitiveness-of-Nicaraguas-Apparel-Industry.pdf/> at 18; Rosemary Westwood, "What Does that \$14 Shirt Really Cost?" Maclean's (1 May 2013), online: Rogers Media <http://www.macleans.ca/economy/business/whatdoes-that-14-shirt-really-cost/>.
} 
geographical boundaries are no longer barriers to commerce. ${ }^{153}$ Due to intricate networks of business and the deeper integration between suppliers and corporations, Rana Plaza can be considered as part of the economic enterprise of LCL. Therefore, since LCL is a multinational corporation with considerable resources, it would not unduly burden the corporation if liability were imposed. Rather, holding LCL liable for the collapse of Rana Plaza would meet tort law's overriding objective of compensating those injured from a risk introduced by the enterprise. Alternatively, if it is harsh holding LCL liable, it is offset by the extent of harshness to the victims if LCL were not held liable. ${ }^{154}$

\section{ii. Deterrence}

In Chapter 2, I have explained the accumulating power and wealth of MNEs. It is remarkable that of the hundred largest concentrations of wealth, $51 \%$ is owned by MNEs and the remaining $49 \%$ is owned by States. ${ }^{155}$ Therefore, in the case of Rana Plaza, holding LCL liable would serve as an example of how MNEs headquartered in Canada should manage their supply chains overseas. By doing so, other MNEs will notice the court's new approach and also exercise strong cautionary measures in fear of being held liable de futuro, as Hudbay has signaled to the legal community. Hudbay will deter parent corporations from engaging in similar conduct as it can otherwise lead to successful litigation against them. What then becomes evident is that while Canadian courts have generally not entertained such complaints, Hudbay heralds a new direction — as can Rana Plaza. Therefore, by considering that Rana Plaza and LCL were part of the same

\footnotetext{
153 Ibid at 24, 40-42; See Chapter 2, supra at 45-48.

154 Robert Thompson, “Unpacking Limited Liability: Direct and Vicarious Liability of Corporate Participants for Torts of the Enterprise"(1994) 47 Vand L Rev 1 at 40 [Thompson].

155 Nicola Jäggers, Human Rights Standards and The Responsibility of Transnational Corporations, ed by Michael Addo (Cambridge, MA: Kluwer Law International, 1999) at 260 [Addo].
} 
economic enterprise and holding the latter liable, it serves as an example to other companies that they must also consider their relationship with their suppliers and ensure a tragedy of 'Rana Plaza magnitude' does not occur, or more importantly, recur.

While the collapse of Rana Plaza was the deadliest structural failure in the history of the world's garment industry, ${ }^{156}$ even after its collapse, it seems that other factory owners have not remained careful, as eight persons were killed when a factory collapsed in 2015, and these collapses and fires are endemic in Bangladesh. ${ }^{157}$ Corporations are well aware, as are shareholders, that they are immune from liability based, first, on limited liability, and second, the separate legal personalities of corporations. ${ }^{158}$ This insulation of liability encourages shareholders to spend little to no money on precautions. ${ }^{159}$

After Rana Plaza collapsed, manufacturers signed the Accord and the Alliance, thereby guaranteeing that they will now financially contribute to the safety of those involved in their business enterprise. ${ }^{160}$ This gives rise to the question of if MNEs can contribute to the safety of employees after the collapse, why did they not do so before, as it could probably have prevented the collapse? This is because they knew that they could not be held legally liable, and therefore, they were not cautious beforehand, but became overcautious afterwards. This 'after the fact' caution arose because they did not wish to seem uncaring about an accident causing deaths,

\footnotetext{
156 “Bangladesh Building Collapse Death Toll Passes 500” BBC News (3 May 2013), online: British Broadcasting Corporation <http://www.bbc.com/news/world-asia-22394094>.

157 “Bangladesh Mongla Cement Factory Kills Eight” BBC News (12 March 2015), online: British Broadcasting Company <http://www.bbc.com/news/world-asia-31849576>; See note 64, supra at Chapter 1.

158 Phillip Blumberg, “Limited Liability and Corporate Groups” (1985-1986) 11 J Corp L 573 at 585 \& $592-594$.

159 Henry Hansmann \& Reinier Kraakman, “Toward Unlimited Shareholder Liability for Corporate Torts” (1991) 100 Yale LJ 1879 at 1881.

160 See Chapter 1, supra at 1-3.
} 
especially since it happened from an enterprise they introduced into the community. Therefore, in terms of limited liability, what must be understood is that it was a political agenda to encourage investments in corporations. However, rapid changes in technology and knowledge have altered the nature of business enterprises that are currently operating overseas, and entity law has become anachronistic. ${ }^{161}$ Therefore, changes in our social thinking regarding the law should also reflect the changing nature of business. ${ }^{162}$

Overall, LCL remains at the juncture to bring positive change in the RMG industry in Bangladesh. They knew of the problems that were percolating in the sector, but failed to take preventive action. The resources available to an MNE places them in a unique position to improve the conditions in the countries where they operate. ${ }^{163}$ As I have explained above, holding LCL liable would not burden the corporation, but would ensure that another Rana Plaza does not recur. Since the GOB has repeatedly failed to regulate the RMG industry, as evinced by numerous factory fires and collapses, ${ }^{164}$ the duty to ensure safety falls upon these MNEs that are benefitting from the cheap labor the country offers. Unfortunately, besides employing locals, MNEs are not really helping the host country. As in, they accept no responsibility towards the safety of those that are fabricating their garments, but are generating massive amounts of profit

\footnotetext{
${ }^{161}$ Phillip Blumberg, "The Transformation of Modern Corporation Law: The Law of Corporate Groups" (2004-2005) 37 Conn L Rev 605 at 607.

162 Jennifer Zerk, Multinationals and Corporate Social Responsibility: Limitations and Opportunities in International Law (Cambridge, UK: Cambridge University Press, 2006) at 15; See Chapter 5 infra, at 124-126 when I recommend establishing the International Board for Corporate Governance.

163 Ilias Bantekas, "Corporate Social Responsibility in International Law” (2004) 22 BU Int'l LJ 309; Carlos Vázquez, "Direct vs. Indirect Obligations of Corporations Under International Law" (2004-2005) 43 Colum J Transnat'l L 927; Henry Hansmann, Reinier Kraakman \& Richard Squire, "Law and the Rise of the Firm" (2006) 119 Harv L Rev 1333; Allison Snyder, "Holding Multinational Corporations Accountable: Is Non-Financial Disclosure the Answer?" (2007) 2007 Colum Bus L Rev 565.

${ }^{164}$ See note 64, supra at Chapter 1.
} 
from this cheap labor. In the globalized world, the connected nature of business makes it so that an action in one part of the world can have great, or grave, consequences in another. ${ }^{165}$ Thus, should countenance be shown for such misconduct owing strictly to corporate law's rigid contours of limited liability, or should the world move towards a more pragmatic approach, marked by the economic relationship between parties, of holding MNEs liable? ${ }^{166}$

\section{F - CONCLUDING COMMENTARY}

Through reference to the above research, it is evident that Adnan was negligent in his conduct towards the victims of the collapse of Rana Plaza. It is also equally evident that LCL knew that New Wave was fabricating its garments, and not PGI, as LCL would otherwise not inspect or hire Bureau Veritas to inspect the facility. Additionally, WRAP cancelled the certificate it granted New Wave due to violations of health and safety, and the report would ultimately be seen by LCL. It is therefore difficult, almost improbable, to believe that LCL was not aware of the risks inherent in the RMG industry of Bangladesh — particularly Rana Plaza.

Next, it is also possible to view Rana Plaza as being part of the economic enterprise of Loblaw Companies Limited. Though employees of LCL were not in charge of operations at New Wave, - they did not direct the means of production — they nonetheless exercised a degree of control over Adnan through consistent contact demanding timely delivery, constituting an overarching control of the business. Therefore, when the totality of the relationship between LCL and New Wave is considered, it is evident that Adnan's business was dependent on LCL, and the

\footnotetext{
${ }^{165}$ Joseph Stiglitz, Globalization and its Discontents (New York: W.W. Norton \& Co, 2002) at 5-7.

166 Frank Easterbrook \& Daniel Fischel, "Limited Liability and the Corporation" (1985) 52 U Chicago L Rev 89; Phillip Blumberg, "Accountability of Multinational Corporations: The Barriers Presented by the Concepts of Corporate Juridical Entity” (2000-2001) 24 Hastings Int'l \& Comp L Rev 297; David Leebron, "Limited Liability, Tort Victims, and Creditors" (1991) 91 Colum L Rev 1565.
} 
opposite is also true. As a result, what LCL demanded, Adnan did not refuse, which truly marks a unity of life between the two parties.

It is this 'unity of life' that alters the relationship between Adnan and LCL. While Adnan was the employer of the victims injured from the collapse of Rana Plaza, he was simultaneously the employee of LCL on the grounds of the above research. That is, due to the merger of Rana Plaza and LCL's activities, combined with the pressure exerted on Adnan by LCL, he became an employee of LCL acting to further its aims.

As a multinational enterprise with considerable resources, the commerce of LCL would not be unduly burdened if it were held liable for the collapse of Rana Plaza. While garment production may not be inherently risky, due to the circumstances of the industry in Bangladesh — marked by a litany of factory fires and collapses — the business enterprise LCL introduced became risky with inherent dangers. Alternatively, even if LCL is inconvenienced from the imposition of liability, it is offset by the greater social good it would accomplish in developing and least developed countries. ${ }^{167}$ Therefore, the ascription of liability on LCL for the injuries resulting from the collapse of Rana Plaza would wholly serve tort law's objective of compensating victims.

While a master was once accountable for every wrongdoing of his servant, wife, and inanimate objects, this changed by the $16^{\text {th }}$ century to limiting the master's liability only for acts he ordered. ${ }^{168}$ The rule changed again in the 1700 s because of the changing nature of business. In the $20^{\text {th }}$ century, vicarious liability further expanded to incorporate a broader class of cases.

\footnotetext{
167 Thompson, supra note 154.

${ }^{168}$ Keeton et al, supra note 10 at 500.
} 
Therefore, if the law of vicarious liability has adjusted to changes in business before, I see no reason as to why it cannot change currently since business relationships have changed even more. Thus, at the outset of my Thesis, I had asked whether LCL can be held accountable for the deaths and injuries from the collapse of Rana Plaza. After an inordinately lengthy discussion, premised on research, I say with conviction that the question can be answered in the affirmative. 


\section{V-CONCLUSION}

In this Thesis, I had set out to determine whether Loblaw Companies Limited could be held liable for the deaths and injuries resulting from the collapse of Rana Plaza, to which I have demonstrated an affirmative answer. To conclude my disquisition, I provide a compendious overview of my findings below.

\section{A - SUMMARY}

First, since the inception of the International Monetary Fund, the World Bank, and the General Agreement on Tariffs and Trade (later evolved into the World Trade Organization), and after the end of the Second World War, trade between nations has consistently increased. The production of goods for the purposes of exportation is primarily led by multinational enterprises. Thus, since the conclusion of the Second World War, MNEs have slowly been amassing power and capital throughout the 1950 s to the 1970 s as the primary drivers of global trade. This was further facilitated by the adoption of neoliberal policies by the world's largest economies — the United States and the United Kingdom.

In search of higher profit margins from cheaper labor, MNEs relocated manufacturing plants overseas. The reduced cost in transportation allowed corporations to outsource production, import the finished goods, and sell their products in domestic markets and yield higher profits than if goods were produced locally. This process gave rise to the term 'globalization.'

Particularly, the garment industry was susceptible to globalization because fabric is impervious to mechanization, making human labor uniquely important.

At this juncture, Bangladesh offered an abundant and cheap labor force, and profit driven corporations could not resist outsourcing to the country. Thus, with numerous MNEs investing in 
Bangladesh the country has become the second largest exporter of readymade garments.

However, the industry's reputation is tainted by factory fires and collapses that have killed more than 2,900 persons (inclusive of Rana Plaza). ${ }^{1}$ While the RMG industry in Bangladesh began flourishing, the accruing power of MNEs frightened some as their activities have removed a President, brought about horrid working conditions, degraded the environment, and committed human rights violations. It is at this point that the question is asked as to who or what governs MNE conduct?

Second, in seeking to answer this question, I have found that MNEs are essentially not governed. International law, even soft law instruments, deals with the behavior of States - not MNEs. Though the OECD Guidelines for Multinational Enterprises, ILO Tripartite Declaration on Principles Concerning Multinational Enterprises and Social Policy, UN Global Compact, and the UN Guiding Principles on Business and Human Rights apply to MNEs, these are soft law instruments. As in, they are binding but carry no sanctioning authority. However, the ability of a corporation to procure profits is directly related to their public image. That is, if people do not approve of the conduct of a corporation, empirical research suggests that they lose revenue. Therefore, to reconstruct their image of being 'socially responsible,' MNEs adopt voluntary codes, as numerous manufacturers have done with the Alliance and the Accord in the aftermath of Rana Plaza. What must be remembered, though, is that these codes are voluntary and the question of legal liability never arose.

Since I had set out to determine liability on the part of LCL, I then turned my attention to tort law to see how courts would determine accountability. The formidable boundaries to

\footnotetext{
${ }^{1}$ See notes $2 \& 64$, supra at Chapter 1.
} 
corporate accountability are separate legal personality and limited liability. As entity law made an approach of finding LCL liable more elusive, I imported the theory of enterprise liability, and revealed how enterprise theory provides a unique solution by viewing the distinct entities of an MNE as one economic enterprise. That is, since the parent company profits from the operations of the subsidiary, the former should be held liable for the misconduct of the latter. Nonetheless, the problem this still poses is that Rana Plaza was not a subsidiary of LCL, and as such, a deeper analysis was warranted to delineate how the factory could be considered as being part of the economic enterprise of LCL.

Using the Supreme Court of Canada's decision of Bazley v Curry, I sought to then situate Rana Plaza within the economic enterprise of LCL and find liability on the latter because it was profiting from the work of the former. First, I demonstrated negligence on the part of Bazlus Adnan. Second, I have shown how New Wave fits into the economic enterprise of LCL by alluding to the consistent contact between the parties, LCL's knowledge that New Wave was fabricating its garments, and that the work being accomplished at New Wave was integral to the business of LCL. Third, while garment production is not inherently risky, I have demonstrated how LCL knowingly introduced a risk into the community based on my research of the social milieu of the garment industry in Bangladesh. At the aggregate sum of these constituent elements, I then have revealed how LCL could be held vicariously liable for Adnan's negligence because Rana Plaza and LCL were involved in the same economic enterprise.

My findings are consistent with observations made by Adolf Berle, Christopher Stone, and Phillip Blumberg. It also speaks to the wider literature of the changing nature of business. In other explanatory words, businesses have become global and a decision in one part of the world 
can have inimical consequences in a geographically distant area, as no region is now remote. Thus, while entity law has its benefits, I have found that enterprise liability is more reflective of the changing nature of global business and multinational enterprises.

\section{i. A Brief Clarification}

Some may suggest that if I recommend holding LCL liable for the collapse of Rana Plaza, then LCL could also be accountable for a cargo ship that capsizes while traveling from Bangladesh to Canada, carrying its merchandise. This is grossly incorrect, as the reason I sought to hold LCL accountable for the collapse of Rana Plaza is because I have demonstrated that they were part of the same enterprise. Due to LCL inspecting Rana Plaza, conscripting Bureau Veritas for the same purpose, and consistently contacting Adnan regarding their merchandise, LCL assumed a role whereby Rana Plaza became part of its enterprise. For example, if LCL also examined the cargo ship, commissioned the services of Intertek for the same purpose, and consistently contacted its Captain so much so that the Captain, in maneuvering his ship over perilous waters to arrive in Canada timely, fortuitously collided with a rock and breached the hull of the ship causing it to capsize, enterprise liability could probably also extend to LCL (however, I abstain from making such a suggestion or prediction).

\section{B - RECOMMENDATION}

\section{i. International Board for Corporate Governance}

Since MNEs operate in multiple jurisdictions, I inquired whether international law regulates their conduct. Then, I have demonstrated that international law does not. While principles of international law and treaties try to sustain international peace, currently, some MNEs have more capital and power than States. Therefore, what was once not realized (MNEs 
could amass such nonpareil power) has since materialized (MNEs amassed such nonpareil power). However, since international law does not apply to MNEs, they are essentially not governed. It is here, for the purposes of global governance, that I propose an institution is established that is vested with the authority to thoroughly govern the conduct of MNEs when they operate overseas. I submit its name to be the International Board for Corporate Governance (hereinafter "IBCG"). The Constitution of the IBCG would outline how it would function and the process it undertakes in its oversight of MNE activity. The IBCG should have a representative body and also provide a forum where aggrieved parties can formally launch complaints (similar to the WTO), which avoids the problematic issue of forum non conveniens.

While I have not discussed every wrongful conduct engaged by MNEs operating overseas, others have and it is widely known what harm some MNEs bring to local communities (along with benefits). An institution with authority to govern MNE conduct would not curtail an MNE's ability to secure profits, but will provide an internationally designated body to which an MNE must report. For example, when a corporation operates in its local country, it is governed by the laws of that nation, and still yields profits from its operations. What I propose by the establishment of the IBCG is that, because there is a disparity between the laws of developed and developing countries regarding standards of operations, a global standard must be developed, codified, and implemented. While the UN Global Compact and the UN Guiding Principles stipulate guidelines that MNEs should follow, the proposed institution's authority would entail what MNEs ought to follow. This would not impair national sovereignty and will provide legally binding guidelines to both the country in which the MNE operates, and the MNE so that both parties are cognizant of their rights. 
As I had explained in Chapter 2, in July 1944, the Bretton Woods Conference gave birth to the IMF and the World Bank (GATT in 1947), but the issue of 'global trade' did not see a formal structure. ${ }^{2}$ It consumed 48 years before such an institution - WTO - was established, which Marco Bronckers predicted could become (and has become) "a key pillar of global governance."3 Between 1947 to 1995 , the GATT essentially transformed itself from an agreement to an international organization addressing Members' trade relations because such an institution did not exist. My intention, with the citation of this example, is to show that States realized (even though the realization occurred in 48 years) that since globalization compressed the world, there was a need for a formal institution governing trade relations. Therefore, I predict that an institution will be established to govern MNE conduct, but it may consume time as States may be reluctant — amid neoliberal policies — to intervene in the market to regulate behavior.

\section{ii. Lack of a Canadian Statute}

As I had mentioned in Chapter 1, the California Transparency in Supply Chains Act (in effect in California) and the Modern Slavery Act 2015 (in effect in the United Kingdom) seek to eradicate the use of slavery and human trafficking in the supply chains of corporations that are headquartered within the territories where the statutes are in effect. ${ }^{4}$ While this is commendable effort on the part of legislatures, which is similar to how Iran abolished child labor in the early 1970s as explained below, I view these statutes as a first step towards a more responsible business environment.

\footnotetext{
2 Peter Van den Bossche, The Law and Policy of the World Trade Organization: Text, Cases and Materials (New York: Cambridge University Press, 2005) at 78-79 [Bossche].

${ }^{3}$ Marco Bronckers, "More Power to the WTO?” (2001) 4 J Int'l Econ L 41 at 44.

${ }^{4}$ The $C T S C A$ imposes a duty on corporations headquartered in California whose global revenue exceeds $\$ 100$ million to disclose information on what measures the company has taken to eradicate slavery and human trafficking in its supply chains. The $M S A$ imposes a similar duty on corporations whose annual revenue exceeds $£ 36$ million.
} 
However, Canada has yet to promulgate an analogous statute that imposes a legal duty on corporations to ensure slavery, human trafficking, and child labor is not used in its supply chains. Therefore, firstly, in accordance with World Vision Canada, I propose that Parliament enact legislation that imposes a duty on corporations headquartered within Canada to bring about transparency in their supply chains. ${ }^{5}$ As in, if a Canadian corporation's annual global revenue exceeds $\$ 150$ million, it ought to be legally required to publicly disclose what it has done to eradicate the use of slavery, human trafficking, and child labor from its supply chains.

Furthermore, $87 \%$ of Canadians think that Parliament should require companies to report on who makes their products and what the company has done to reduce child labor in its supply chains. ${ }^{6}$

Otherwise, Canadians are inadvertently permitting this problem to continue.

Secondly, I add that the following two provisions, along with the subsections, be included in the proposed legislation:

1. A corporation headquartered within the territorial borders of Canada shall, 1. Prior to the inception of business, ensure that those working to provide its products, whether locally or overseas, are working in conditions that are safe and free from foreseeable peril;

2. Work to uncover who its supplier is even if that supplier is a subcontractor and not the company to whom the Canadian company had originally outsourced the contract;

3. Send its employees on a biannual basis to ensure compliance with subsection (1).

2. The company cannot relieve itself of the duties imposed under section (1) and the subsections contained therein on account that it did not know which supplier was providing its products.

\footnotetext{
${ }^{5}$ Supply Chain Risk Report: Child and Forced Labour in Canadian Consumer Products" World Vision: For Children. For Change. For Life (8 June 2016), online: World Vision Canada <http://nochildforsale.ca/wp-content/ uploads/2016/06/Child-and-forced-labour-report jun-08.pdf\#> at 2 [World Vision Canada]; Also see "List of Goods Produced by Child Labor or Forced Labor" Bureau of International Labor Affairs, United States Department of Labor (1 December 2014), online: United States Department of Labor $<$ https://www.dol.gov/ilab/reports/pdf/ TVPRA_Report2014.pdf $\$$.

${ }^{6}$ World Vision Canada, ibid at 18.
} 
Thus, the inclusion of the above two provisions would impose a legal duty upon corporations to ensure that its suppliers' employees are working in safe conditions. Only through the introduction of such a legislation in Canada would the public be made aware of the conditions under which a product is made overseas. Additionally, this would demonstrate to the world that Canada is willing to prevent the recurrence of another Rana Plaza.

\section{C - FUTURE RESEARCH}

In the preceding section, while I have proposed the establishment of the IBCG, I draw attention to the fact that this organization would govern MNE conduct only when the relationship between the parties is of a 'parent company and subsidiary.' Thus, the complex legal relationship of Rana Plaza would still fall outside the scope of this organization. Therefore, while I have relied on the law to provide a solution — and I am making an ancillary recommendation — the issue of Rana Plaza (and the RMG industry in Bangladesh as a whole) would perhaps be better addressed by the Government of Bangladesh, worker representatives, employer representatives, and representatives from multinational enterprises (from proposed institution above) working harmoniously together to bring about a sustainable solution.

\section{i. Changes are not Impossible}

The world's garment industry is particularly troubled by 'sweatshop practices', which is a business that violates both wage or child labor laws and health regulations. ${ }^{7}$ With the passage of time, while I do not suggest that conditions have improved everywhere, few improvements warrant consideration. In the early 1970s, the Government of Iran officially abolished the use of

\footnotetext{
${ }^{7}$ Lora Jo Foo, "The Vulnerable and Exploitable Immigrant Workforce and the Need for Strengthening Worker Protective Legislation" (1994) 103 Yale LJ 2179 at 2181 [Jo Foo]; The word 'sweatshop' dates back to the late 1800s when employers would 'sweat' as much profit from each worker as possible, at Allison Gormley, "The Underground Exposed: The United States Corporations' Use of Sweatshops Abroad, and the Abuse of Women" (2001-2002) 25 Suffolk Transnat'l L Rev 109 at 110.
} 
child labor in the carpet industry. ${ }^{8}$ In the United States, the Joint Enforcement Strike Force, created by then California Governor Pete Wilson on 26 October 1993, ${ }^{9}$ ended the 'slave-like' working conditions of 72 Thai persons at the El Monte community of Los Angeles. ${ }^{10}$ Because of globalization, The Triangle Shirtwaist Company fire of 1911 in New York City, which killed 150 women, prompted the government to take worker rights of garment employees more seriously. ${ }^{11}$ I cite these examples because they are lucid illustrations of positive change that can occur when the government initiates the drive to overhaul practices of an industry.

However, developing countries remain reluctant to regulate the conduct of MNEs in fear that the business will be taken to another country. For example, while Iran was successful in the abolishment of child labor in its carpet industry, the size of the sector rapidly declined when MNEs moved manufacturing to India, where child labor is prevalent. ${ }^{12}$ India earned between \$265 million to \$275 million in 1990 from the exportation of carpets, making the industry a significant source of foreign exchange for the country. ${ }^{13}$ Considering the economy of Bangladesh, as I have described in Chapter 2, the GOB may continuously display hesitance in regulating the conduct of multinational enterprises. ${ }^{14}$ Therefore, I sincerely propose that a group of representatives (employer, employee, MNEs), along with the GOB, formulate a solution to the

\footnotetext{
8 Daniel Ehrenberg, “The Labor Link: Applying the International Trading System to Enforce Violations of Forced and Child Labor" (1995) 20 Yale J Int'l L 361 at 371 [Ehrenberg]; See China's prison labor system at 366-368, and the use of forced and child labor in the Dominical Republic's sugarcane industry at 369-370.

${ }^{9}$ Jo Foo, supra note 7 at 2179.

${ }^{10}$ Laura Ho, Catherine Powell \& Leti Volpp, “(Dis)assembling Rights of Women Workers Along the Global Assembly Line: Human Rights and the Garment Industry" (1996) 31 Harv CR-CLL Rev 383 at 383.

${ }^{11}$ Ibid at 387-388.

${ }^{12}$ Ehrenberg, supra note 8 at 371-374.

${ }^{13}$ Ibid.

${ }^{14}$ See Chapter 2, supra at 36-45.
} 
endemic problem of the RMG sector in Bangladesh. As in, when a diverse group works together, they are more likely to produce a solution that is acceptable to all involved parties, as opposed to one party unilaterally concocting a solution and imposing it on others, which will be unacceptable to those it disfavors.

\section{ii. What Will Happen?}

To better understand how the actual litigation against Loblaws will proceed, it would be useful to remain abreast hearings of the Ontario Superior Court of Justice, particularly on 19 September 2016 - the date on which the complaint will be heard by a judge. If a court in Canada rules to hear the case, it will send shockwaves throughout the legal and business communities. As I have mentioned in my project, MNEs remain well-insulated against liability due to the use of intricate webs of subsidiaries, and in the case of Rana Plaza, the latter was not even a subsidiary, which makes imposing liability on LCL more difficult. Therefore, if a court nonetheless chooses to entertain the complaint on grounds of enterprise theory, it will mark the beginning of a new chapter for Canada's future. This would demonstrate to the world that Canada remains at the forefront of placing great importance on corporate social responsibility.

Alternatively, if the court dismisses the action (and I do not submit a prediction), Canada is essentially granting licenses to its corporations to move overseas and engage in 'whatever' conduct it pleases solely because of a political concept that was formulated in the nineteenth century - limited liability. However, if the court dismisses the action, I envision that the judgment will be replete with lament when considering the social issues in the RMG industry in Bangladesh. Notwithstanding the court's ruling, academics, lawyers, and legislators would benefit from more extensive research that reveal the operations, whether praiseworthy or 
meriting opprobrium, of MNEs so that a disaster with commensurate magnitude of Rana Plaza does not recur. This is why further research into how the deplorable conditions of Bangladesh's garment sector can be improved, and how MNEs can contribute to a better environment would be greatly luminous; again, with a solution that benefits all involved parties. 


\section{REFERENCES}

\section{LEGISLATION}

Bangladesh Labour Act, 2006 (Bangladesh), XLII of 2006

Marrakesh Agreement Establishing the World Trade Organization, 15 April 1994, 1867 UNTS 154, (entered into force 1 January 1995)

The Building Construction Act, 1952 (Bangladesh), Act No 2 of 1953

\section{CASE LAW}

642947 Ontario Ltd v Fleischer, [2001] OJ No 4771

671122 Ontario Ltd v Sagaz Industries Canada Inc, [2001] 2 SCR 983

A.C.I. Stamping and Spinning Proprietary Limited v Boczulik, [1964] HCA 26, 110 CLR 372

Atco Ltd v Calgary Power Ltd, [1982] 2 SCR 557

Bankstown Foundry Proprietary Limited v Braistina, [1986] HCA 20

Bazley v Curry, [1999] 2 SCR 534

Berkey v Third Avenue Railway Company, 155 NE 914 (1927)

Bolton v Stone, [1951] 1 All ER 1078

Chamberland v Fleming, [1984] AWLD 832

Choc v Hudbay Minerals Inc, [2013] OJ No 3375, 2013 ONSC 1414

Cooper v Hobart, [2001] 3 SCR 537

Crocker v Sundance Northwest Resorts Limited, [1988] 1 SCR 1186

Donoghue v Stevenson, [1932] All ER Rep 1, [1932] AC 562

Garcia v Tahoe Resources Inc., [2015] BCSC 2045

Helen Palsgraf v The Long Island Railroad Company, 248 NY 339 (1928) 
Hendricks $v R$, [1970] SCR 237

JGE v English Province of Our Lady of Charity, [2012] EWCA Civ 938

Kay v ITW Limited, [1967] 3 All ER 22

Kamloops $v$ Nielsen, [1984] 2 SCR 2

Koeppel v Colonial Coach Lines Limited, [1933] 3 DLR 469

Kiobel v Royal Dutch Petroleum Co, 133 S Ct 98 (2013)

Lepine v Demeule, [1973] 3 WWR 732

London Drugs Ltd v Kuehne \& Nagel International Ltd, [1992] 3 SCR 299

McHale v Watson, [1966] HCA 13, 115 CLR 199

Mustapaha v Culligan of Canada Limited, [2008] 2 SCR 114

Olson v Sprung Instant Greenhouses Ltd, [1985] 41 Alta LR (2d) 325

O’Reilly v National Rail \& Tramway Appliances Limited, [1966] 1 All ER 499

Parkland Plumbing \& Heating Ltd v Minaki Lodge Resort, [2009] ONCA 256

Reibl v Hughes, [1980] 2 SCR 880

Rozenhart v Skier's Sport Shop (Edmonton) Limited, [2004] 9 WWR 527

Salomon v Salomon \& Co Ltd, [1897] AC 22, 66 LJ Ch 35

Saskatchewan Economic Development Corp v Patterson-Boyd Manufacturing Corp, PB Fabricators Ltd, and Western Metal \& Supply Co Ltd, [1981] 2 WWR 40

Shoppers Drug Mart Inc v 6470360 Canada Inc (Energyshop Consulting Inc/Powerhouse Energy Management Inc), 2014 ONCA 85

South Australian Ambulance Service v Wahlheim, [1948] HCA 32, 77 CLR 215

Stevenson, Jordan \& Harrison Limited v MacDonald \& Evans, [1952] 1 TLR 101

The Wagon Mound (No 2), [1966] 2 All ER 709 
Transamerica Life Insurance Co of Canada v Canada Life Assurance Co, [1996] OJ No 1568

Toronto (City of) v Famous Players' Canadian Corp, [1935] OR 314

United States v Carroll Towing Company, 159 F 2d 169 (2d Cir Ct of App 1947)

United States of America v Lépine, [1994] 1 SCR 286

Vile v Von Wendt, [1979] OJ No 4421, 103 DLR (3d) 356

Walmsley v Humenick, [1954] 2 DLR 332

Wilsons \& Clyde Coal Company Limited v English, [1937] 3 All ER 628

Yorkton Agricultural \& Industrial Exhibition Association v Morley, [1967] 66 DLR (2d) 37

\section{SECONDARY MATERIAL: BOOKS}

Addo, Michael, ed, Human Rights Standards and The Responsibility of Transnational Corporations (The Netherlands: Kluwer Law International, 1999)

Alexander, Paula, Corporate Social Irresponsibility (New York: Routledge, 2015)

Atiyah, Patrick, Vicarious Liability in the Law of Torts (London: Butterworth \& Co Ltd, 1967)

Bakan, Joel, The Corporation: The Pathological Pursuit of Profit and Power (Toronto: Penguin Canada, 2004)

Bernard, Chester, The Functions of the Executive (Cambridge, MA: Harvard University Press, 1938)

Black, John, Hashimzade, Nigar \& Myles, Gareth, A Dictionary of Economics, $4^{\text {th }}$ ed (Oxford: Oxford University Press, 2012)

Blumberg, Phillip, The Multinational Challenge to Corporation Law: The Search for a New Corporate Personality (New York: Oxford University Press, 1993)

Blumberg, Phillip, The Law of Corporate Groups: Procedural Problems in the Law of Parent and Subsidiary Corporations (Boston: Little, Brown and Company, 1983)

Blumberg, Phillip \& Strasser, Kurt, The Law of Corporate Groups: Problem of Parent and Subsidiary Corporations Under Statutory Law Specifically Applying Enterprise Principles (Boston: Little, Brown \& Company, 1992) 
Boyle, Alan \& Chinkin, Christine, The Making of International Law (New York: Oxford University Press, 2007)

Brodie, Douglas, Enterprise Liability and the Common Law (New York: Cambridge University Press, 2010)

Byers, Michael, ed, The Role of Law in International Politics: Essays in International Relations and International Law (New York: Oxford University Press, 2000)

Clark, John, Social Control of Business, $2^{\mathrm{d}}$ ed (New York: McGraw Hill, 1939)

Cline, Elizabeth, Overdressed: The Shockingly High Cost of Cheap Fashion (New York: Penguin, 2012)

Cowling, Keith \& Sugden, Roger, Transnational Monopoly Capitalism (New York: St. Martin’s Press, 1987)

Easterbrook, Frank \& Fischel, Daniel, The Economic Structure of Corporate Law (Cambridge, MA: Harvard University Press, 1991)

Feltham, Ivan, Lifting the Corporate Veil (Toronto: R. De Boo, 1968)

Fleming, John, The Law of Torts, $9^{\text {th }}$ ed (Sydney: LBC Information Services, 1998)

Friedman, Milton, Capitalism and Freedom (Chicago: University of Chicago Press, 2002)

Garner, Bryan, Jackson, Tiger, Newman, Jeff, Cheng, Karolyne, Hammond, Herbert, Melendez, Brian, Schwing, Ann, Shapiro, Fred, Spaniol Jr., Joseph, \& Elster, Charles, eds, Black's Law Dictionary, $9^{\text {th }}$ ed (St. Paul, Minn: West Publishing Co, 2009)

Glasbeek, Harry, Wealth by Stealth: Corporate Crime, Corporate Law, and the Perversion of Democracy (Toronto: Between the Lines, 2002)

Gower, Lawrence, Modern Company Law, $3^{\text {rd }}$ ed (London: Sweet \& Maxwell, 1969)

Harvey, David, A Brief History of Neoliberalism (New York: Oxford University Press Inc, 2005)

Hayek, Friedrich, The Constitution of Liberty (Chicago: University of Chicago Press, 1960)

Hayek, Friedrich, The Road to Serfdom (London: George Routledge \& Sons, 1944)

Held, David \& McGrew, Anthony, Globalization/Anti-Globalization (Malden, MA: Blackwell Publishers, 2002) 
Heuston, Robert \& Buckley, Richard, Salmond and Heuston on the Law of Torts, $19^{\text {th }}$ ed (London: Sweet \& Maxwell, 1987)

Higgins, Rosalyn, Problems and Process: International Law and How We Use it (New York: Oxford University Press, 1994)

Hobson, John, Towards International Government (New York: MacMillan Company, 1916)

Hopkins, Michael, The Planetary Bargain: Corporate Social Responsibility Matters (Sterling, VA: Earthscan Publications, 2003)

Islam, Shariful, Politics - Corruption Nexus in Bangladesh: An Empirical Study of the Impacts on Judicial Governance (Kowloon, Hong Kong: Asian Legal Resource Centre, 2010)

Jones, Campbell, Parker, Martin \& Bos, René ten, Business Ethics: A Critical Approach (New York: Routledge, 2005)

Jones, Geoffrey, Multinationals and Global Capitalism: From the Nineteenth to the Twenty First Century (Oxford: Oxford University Press, 2004)

Keeton, Page, Dobbs, Dan, Keeton, Robert \& Owen, David, eds, Prosser and Keeton on The Law of Torts, $5^{\text {th }}$ ed (St. Paul, Minn: West Publishing Co, 1984)

Korten, David, When Corporations Rule the World, 2d ed (San Francisco: Berrett-Koehler Publishers, 2001)

Lechner, Frank \& Boli, John, eds, The Globalization Reader, $5^{\text {th }}$ ed (Hoboken, NJ: WileyBlackwell, 2015)

Linden, Allen \& Feldthusen, Bruce, Canadian Tort Law, $9^{\text {th }}$ ed (Markham, ON: LexisNexis Canada Inc, 2011)

MacNeil, Michael, Sargent, Neil \& Swan, Peter, eds, Regulation, and Governance (Toronto: Oxford University Press, 2002)

Marks, Susan \& Clapham, Andrew, International Human Rights Lexicon (Toronto: Oxford University Press, 2005)

Moran, Theodore, Multinational Corporations and the Politics of Dependence: Copper in Chile (Princeton, NJ: Princeton University Press, 1974)

Muchlinski, Peter, Multinational Enterprises and the Law, 2d ed (New York: Oxford University Press Inc, 2007) 
Mullany, Nicholas \& Linden, Allen, eds, Torts Tomorrow: A Tribute to John Fleming (Sydney: LBC Information Services, 1998)

Nolan, Virginia \& Ursin, Edmund, Understanding Enterprise Liability: Rethinking Tort Reform for the Twenty-first Century (Philadelphia: Temple University Press, 1995)

Owen, Howard, Social Responsibilities of the Businessman (New York: Harper, 1953)

Ricardo, David, The Principles of Political Economy and Taxation (London: J.M. Dent \& Sons Ltd, 1911)

Robertson, Roland, Globalization: Social Theory and Global Culture (London, UK: Sage, 1992)

Rugman, Alan \& Brewer, Thomas, eds, Oxford Handbook of International Business (Oxford: Oxford University Press, 2001)

Slaughter, Anne-Marie, A New World Order (Princeton, NJ: Princeton University Press, 2004)

Stapleton, Jane, Product Liability (London: Butterworth \& Co Ltd, 1994)

Stiglitz, Joseph, Globalization and its Discontents (New York: W.W. Norton \& Co, 2002)

Trebilcock, Michael, Howse, Robert \& Eliason, Antonia, The Regulation of International Trade, $4^{\text {th }}$ ed (New York: Routledge, 2013)

Tugendhat, Christopher, The Multinationals (London: Eyre and Spottiswoode, 1971)

Van den Bossche, Peter, The Law and Policy of the World Trade Organization: Text, Cases and Materials (New York: Cambridge University Press, 2005)

Vernon, Raymon, Sovereignty at Bay: The Multinational Spread of U.S. Enterprises (New York: Basic Books, 1971)

Waddams, Edmund, Dimensions of Private Law (New York: Cambridge University Press, 2003)

Waters, Donald, Supply Chain Management: An Introduction to Logistics, $2^{\mathrm{d}}$ ed (New York: Palgrave Macmillan, 2009)

Weiss, Linda, The Myth of the Powerless State (Ithaca, NY: Cornell University Press, 1998)

Weiss, Thomas, Governing the World? Addressing "Problems without Passports" (Colorado: Paradigm Publishers, 2014) 
Weiss, Thomas \& Thakur, Ramesh, Global Governance and the UN: An Unfinished Journey (Indiana: Indiana University Press, 2010)

Wilkins, Mira, The Emergence of Multinational Enterprise: American Business Abroad from the Colonial Era to 1914 (Cambridge, MA: Harvard University Press, 1970)

Zerk, Jennifer, Multinationals and Corporate Social Responsibility: Limitations and Opportunities in International Law (Cambridge, UK: Cambridge University Press, 2006)

\section{SECONDARY MATERIAL: ARTICLES}

Antunes, José, “The Liability of Polycorporate Enterprises” (1998-1999) 13 Conn J Int'1 L 197

Ataner, Attila, "How Strict is Vicarious Liability? Reassessing the Enterprise Risk Theory" (2006) 64 UT Fac L Rev 63

Ayoub, Lena, “Nike Just Does It - And Why the United States Shouldn't: The United States' International Obligation to Hold MNCs Accountable for their Labor Rights Violations Abroad" (1998-1999) 11 DePaul Bus LJ 395

Baez, Christina, Dearing, Michelle, Delatour, Margaret \& Dixon, Christine, "Multinational Enterprises and Human Rights" (1999-2000) 8 U Miami Int'l \& Comp L Rev 183

Bainbridge, Stephen, “Abolishing Veil Piercing” (2000-2001) 26 J Corp L 479

Bansal, Pratima \& Clelland, Iain, "Talking Trash: Legitimacy, Impression Management, and Unsystematic Risk in the Context of the Natural Environment" (2044) 47 Academy of Management J 93

Bantekas, Ilias, "Corporate Social Responsibility in International Law" (2004) 22 BU Int'l LJ 309

Berle Jr., Adolf, "The Theory of Enterprise Entity” (1947) 47 Colum L Rev 343

Blumberg, Phillip, "Accountability of Multinational Corporations: The Barriers Presented by Concepts of the Corporate Juridicial Entity" (2000-2001) 24 Hastings Int'1 \& Comp L Rev 297

Blumberg, Phillip, “Limited Liability and Corporate Groups" (1985-1986) 11 J Corp L 573

Blumberg, Phillip, "The Increasing Recognition of Enterprise Principles in Determining Parent and Subsidiary Corporation Liabilities" (1995-1996) 28 Conn L Rev 295 
Blumberg, Phillip, "The Transformation of Modern Corporation Law: The Law of Corporate Groups” (2004-2005) 37 Conn L Rev 605

Bronckers, Marco, “More Power to the WTO?” (2001) 4 J Int'1 Econ L 41

Brown, Phillip \& Lauder, Hugh, "Education, Globalization and Economic Development" (1996) 11 J Education Pol'y 1

Cachon, Gérard \& Swinney, Robert, "The Value of Fast Fashion: Quick Response, Enhanced Design, and Strategic Consumer Behavior" (2011) 57 Management Science 778

Calabresi, Guido, "Some Thoughts on Risk Distribution and the Law of Torts" (1961) 70 Yale LJ 499

Caleca, Alexandra, "The Effects of Globalization on Bangladesh's Ready-Made Garment Industry: The High Cost of Cheap Clothing" (2014) 40 Brook J Int'l L 279

Callison, William, "Rationalizing Limited Liability and Veil Piercing” (2003) 58 Bus Law 1063

Carroll, Archie, "Corporate Social Responsibility: Evolution of a Definitional Construct" (1999) 38 Bus \& Society 268

Charlesworth, Hilary, Chinkin, Christine \& Wright, Shelley, "Feminist Approaches to International Law" (1991) 85 Am J Int'l L 613

Chimni, Bhupinder, “An Outline of a Marxist Course on Public International Law” (2004) 17 Leiden J Int'l L 1

Chinkin, Christine, "The Challenge of Soft Law: Development and Change in International Law" (1989) 38 ICLQ 850

Chowdhury, Bhagwan \& Howe, Jonathan, “Corporate Risk Management for Multinational Corporations: Financial and Operational Hedging Policies" (1999) 2 European Financial Review 229

Clay, Lisa, "The Effectiveness of the Worker Rights Provisions of the Generalized System of Preferences: the Bangladesh Case Study" (2001) 11 Transnat'1 L \& Contemp Probs 175

Cleveland, Sarah, "Global Labor Rights and the Alien Tort Claims Act" (1997-1998) 76 Tex L Rev 1533

Cobb-Walgren, Cathy, Ruble, Cynthia \& Donthu, Naveen, "Brand Equity, Brand Preference, and Purchase Intent" (1995) 24 J Advertising 25 
Coffee Jr., John, “Litigation Governance: Taking Accountability Seriously” (2010) 110 Colum L Rev 288

Compa, Lance \& Hinchcliffe-Darricarrère, Tashia, "Enforcing International Labor Rights through Corporate Codes of Conduct” (1995) 33 Colum J Transnat'1 L 663

Davis, Keith, “Can Business Afford to Ignore Social Responsibilities?” (1960) 2 Cal Management Rev 70

Dearborn, Meredith, "Enterprise Liability: Reviewing and Revitalizing Liability for Corporate Groups" (2009) 97 Cal L Rev 195

Dix, Maurice, “The Economic Entity” (1953) 22 Fordham L Rev 254

Douglas, William, "Vicarious Liability and Administration of Risk" (1929) 38 Yale LJ 584

Easterbrook, Frank \& Fischel, Daniel, "Limited Liability and the Corporation” (1985) 52 U Chicago L Rev 89

Ehrenberg, Daniel, “The Labor Link: Applying the International Trading System to Enforce Violations of Forced and Child Labor" (1995) 20 Yale J Int'l L 361

Farquhar, Peter, "Managing Brand Equity” (1989) 1 Marketing Research 24

Flannigan, Robert, “Enterprise Control: The Servant-Independent Contractor Distinction” (1987) 37 UTLJ 25

Galanter, Marc,"Bhopals, Past and Present: The Changing Legal Response to Mass Disaster" (1990) 10 Windsor YB Access Just 151

Gevurtz, Franklin, "Piercing Piercing: An Attempt to Lift the Veil of Confusion Surrounding the Doctrine of Piercing the Corporate Veil” (1997) 76 Or L Rev 853

Gillen, Maria, “The Apparel Industry Partnership's Free Labor Association: A Solution to the Overseas Sweatshop Problem or the Emperor's New Clothes?” (1999-2000) 32 NYUJ Int'1 L \& Pol 1059

Gormley, Alison, “The Underground Exposed: The United States Corporations' Use of Sweatshops Abroad, and the Abuse of Women" (2001-2002) 25 Suffolk Transnat'1 L Rev 109

Green, Leon, “The Negligence Issue” (1928) 37 Yale LJ 1029 
Guzman, Andrew \& Meyer, Timothy, "International Common Law: The Soft Law of International Tribunals" (2009) 9 Chicago J Int'l L 515

Leebron, David, “Limited Liability, Tort Victims, and Creditors" (1991) 91 Colum L Rev 1565

Hamelink, Cees, “The Elusive Concept of Globalisation” (1999) 1 Global Dialogue 1

Hamilton, Robert, “The Corporate Entity” (1970) 49 Tex L Rev 979

Hansmann, Henry \& Kraakman, Reinier, "Toward Unlimited Shareholder Liability for Corporate Torts" (1991) 100 Yale LJ 1879

Hansmann, Henry, Kraakman, Reinier \& Squire, Richard, "Law and the Rise of the Firm" (2006) 119 Harv L Rev 1333

Hartmann, Julia \& Moeller, Sabine, "Chain Liability in Multitier Supply Chains? Responsibility Attributions for Unsustainable Supplier Behavior" (2014) 23 J Operations Management 281

Healy, Paul \& Palepu, Krishna, “The Fall of Enron” (2003) 17 J Econ Perspectives 3

Heuston, Robert, "Donoghue v. Stevenson in Retrospect" (1957) 20 Mod L Rev 1

Ho, Laura, Powell, Catherine \& Volpp, Leti, “(Dis)assembling Rights of Women Workers Along the Global Assembly Line: Human Rights and the Garment Industry" (1996) 31 Harv CRCLL Rev 383

Holmes Jr., Oliver Wendell, “Agency” (1891-1892) 5 Harv L Rev 1

Hong, Jane, "Enforcement of Corporate Codes of Conduct: Finding a Private Right of Action for International Laborers Against MNCs for Labor Rights Violation" (2000-2001) 19 Wis Int'l LJ 41

Huntington, Samuel, “The Clash of Civilizations?” (1993) 72 Council on Foreign Relations 22

Jo Foo, Lora, "The Vulnerable and Exploitable Immigrant Workforce and the Need for Strengthening Worker Protective Legislation" (1994) 103 Yale LJ 2179

Johns, Fleur, "The Invisibility of the Transnational Corporation: An Analysis of International Law and Legal Theory" (1993-1994) 19 Melbourne UL Rev 893

Kinley, David \& Tadaki, Junko, "From Talk to Walk: The Emergence of Human Rights Responsibilities for Corporations at International Law" (2003-2004) 44 Va J Int'l L 931 
Kuzmarov, Betina, "Unilateral Acts in International Relations: Accepting the Limits of International Law" (2005) 8 YB New Zealand Juris 77

Landers, Jonathan, "A Unified Approach to Parent, Subsidiary, and Affiliate Questions in Bankruptcy” (1975) 42 U Chicago L Rev 589

Laski, Harold, “The Basis of Vicarious Liability” (1916) 26 Yale LJ 105

Leebron, David, “Limited Liability, Tort Victims, and Creditors" (1991) 91 Colum L Rev 1565

Mahoney, Paul, "The Common Law and Economic Growth: Hayek Might be Right" (2001) $30 \mathrm{~J}$ Legal Stud 503

Manne, Henry, "Our Two Corporation Systems: Law and Economics" (1967) 53 Va L Rev 259

Mattoo, Aaditya \& Wunsch-Vincent, Sacha, "Pre-empting Protectionism and Outsourcing: The GATS and Outsourcing” (2004) 7 J Int'1 Econ L 765

Mendelson, Nina, "A Control-Based Approach to Shareholder Liability for Corporate Torts” (2002) 102 Colum L Rev 1203

Motlagh, Jason \& Saha, Atish, "The Ghosts of Rana Plaza: In Bangladesh, One Year After the Worst Accident in the History of the Garment Industry, Recovery Remains a Fragile Process, Justice Seems Elusive, and Reform has a Long Way to Go" (2014) 90 Va Q Rev 44

Muchlinski, Peter, "Human Rights and Multinationals: Is there a Problem?" (2001) 77 Royal Institute Int'l Affairs 31

Murray, Jill, "A New Phase in the Regulation of Multinational Enterprises: The Role of the OECD” (2001) 30 Indus LJ 255

Parpart, Jane and Veltmeyer, Henry, "The Development Project in Theory and Practice: A Review of its Shifting Dynamics” (2004) 25 Can J Dev Stud 39

Paul, Louis \& Reich, Simon, "National Structures and Multinational Corporate Behavior: Enduring Differences in the Age of Globalization" (1997) 51 Int'l Organization 1

Peña, Susana, "Human Rights Violations by Canadian Companies Abroad: Choc v Hudbay Minerals Inc" (2014) 5 West J Legal Stud 3

Phillips, Robert and Caldwell, Craig, "Value Chain Responsibility: A Farewell To Arm's Length" (2005) 110 Bus \& Soc'y Rev 345 
Posner, Richard, "The Rights of Creditors of Affiliated Corporations" (1976) 43 U Chicago L Rev 499

Priest, George, "The Invention of Enterprise Liability: A Critical History of the Intellectual Foundations of Modern Tort Law" (1985) 14 J Legal Stud 461

Prosser, William, "Palsgraf Revisited” (1953) 52 Mich L Rev 1

Ratner, Steven \& Slaughter, Anne-Marie, “Appraising the Methods of International Law: A Prospectus for Readers” (1999) 93 Am J Int'l L 291

Rott, Peter \& Ulfbeck, Vibe, "Supply Chain Liability of Multinational Corporations?” (2015) 23 ERPL 415

Sacharoff, Ariadne, "Multinationals in Host Countries: Can They be Held Liable Under the Alien Tort Claims Act for Human Rights Violations?” (1997-1998) 23 Brook J Int'l L 927

Schane, Sanford, "The Corporation is a Person: The Language of a Legal Fiction" (1986-1987) 61 Tul L Rev 563

Slaughter, Anne-Marie, "International Law and International Relations Theory: A Dual Agenda” (1993) 87 Am J Int’l L 205

Smith, Bryant, "Legal Personality" (1928) 37 Yale LJ 283

Snider, Laureen, “Cooperative Models and Corporate Crime: Panacea or Cop-Out?” (1990) 36 Crime \& Delinquency 373

Snyder, Allison, "Holding Multinational Corporations Accountable: Is Non-Financial Disclosure the Answer?" (2007) 2007 Colum Bus L Rev 565

Spinanger, Dean, "Will the Multi-Fibre Arrangement Keep Bangladesh Humble" (1987) 10 World Economy 75

Stephens, Beth, "Corporate Liability: Enforcing Human Rights Through Domestic Litigation” (2000-2001) 24 Hastings Int'l \& Comp L Rev 401

Stone, Christopher, "The Place of Enterprise Liability in the Control of Corporate Conduct" (1980) 90 Yale LJ 1

Strasser, Kurt, "Piercing the Veil in Corporate Groups" (2004-2005) 37 Conn L Rev 637 
Swain, John \& Aguilar, Edwin, "Piercing the Veil to Assert Personal Jurisdiction Over Corporate Affiliates: An Empirical Study of the Cannon Doctrine" (2004) 84 BUL Rev 445

Sykes, Alan, "The Boundaries of Vicarious Liability: An Economic Analysis of the Scope of Employment Rule and Related Legal Doctrines" (1988) 101 Harv L Rev 563

Terry, Henry, "Negligence” (1915) 29 Harv L Rev 40

Thompson, Robert, "Piercing the Corporate Veil: An Empirical Study" (1990-1991) 76 Cornell L Rev 1036

Tomášek, Ladislav, Darby, Sarah, Fearn, Thomas, Swerdlow, Anthony, Plaček, Václav \& Kunz, Emil, "Patters of Lung Cancer Mortality Among Uranium Miners in West Bohemia with Varying Rates of Exposure to Radon and its Progeny" (1994) 137 Radiation Research 251

Trotter, Richard Clayton, Day, Susan \& Love, Amy, "Bhopal, India and Union Carbide: The Second Tragedy" (1989) 8 J Bus Ethics 439

Vagts, Detlev, “The Multinational Enterprise: A New Challenge for Transnational Law” (1970) 83 Harvard L Rev 739

Vázquez, Carlos, “Direct vs. Indirect Obligations of Corporations Under International Law" (2004-2005) 43 Colum J Transnat'l L 927

Weeramantry, Christopher, "Human Rights and the Global Marketplace” (1999) 25 Brook J Int'l L 27

Zahra, Shaker, "The Changing Rules of Global Competitiveness in the 21st Century" (1999) 13 Academy of Management 36

\section{INTERNATIONAL ORGANIZATIONS: REPORTS \& PAPERS}

"Bangladesh" The World Bank (2016), online: The World Bank Group: IBRD. IDA < http:// www.worldbank.org/en/country/bangladesh>

"Bangladesh: Decent Work Country Programme, 2012-2015" International Labour Organization (November 2012), online: International Labour Organization $<$ http://www.ilo.org/public/ english/bureau/program/dwcp/download/bangladesh.pdf>

"Bangladesh: Seeking Better Employment Conditions for Better Socioeconomic Outcomes" International Labour Organization (2013), online: International Labour Organization, International Institute for Labour Studies < http://www.ilo.org/wcmsp5/groups/public/--dgreports/---dcomm/documents/publication/wcms_229105.pdf $>$ 
"Data: Bangladesh" The World Bank (2016), online: The World Bank: IBRD. IDA < http:// data.worldbank.org/country/bangladesh>

Ernst, Christoph, Ferrer, Alfons \& Zult, Daan, "The End of the Multi-Fibre Arrangement and its Implications for Trade and Employment” International Labour Organization (2005), online: International Labour Organization <http://ilo.org/wcmsp5/groups/public/---ed_emp/--emp_elm/documents/publication/wcms_114030.pdf $>$

"Export Processing Zones" The World Bank (December 1998), online: The World Bank Group: IBRD. IDA < http://www1.worldbank.org/prem/PREMNotes/premnote11.pdf>

Gimenez, Lea, Ahmed, Faizuddin, Sharif, Iffath \& Jolliffe, Dean, "Bangladesh Poverty Assessment: Assessing a Decade of Progress in Reducing Poverty, 2000-2010" The World Bank Bangladesh Development Series Paper No. 31 (June 2013), online: The World Bank $<$ http://www-wds.worldbank.org/external/default/WDSContentServer/WDSP/IB/ 2013/06/19/000333037_20130619115421/Rendered/PDF/ 785590NWP0Bang00Box0377348B0PUBLIC0.pdf>

"Guiding Principles on Business and Human Rights" United Nations Human Rights Office of the High Commissioner (2011), online: OHCHR <http://www.ohchr.org/Documents/ Publications/GuidingPrinciplesBusinessHR_EN.pdf $>$

"ILO Report Presents a Path to Sustainable Growth in Bangladesh" International Labour Organization (18 November 2013), online: International Labour Organization <http:// www.ilo.org/global/about-the-ilo/newsroom/news/WCMS_229135/lang--en/index.htm>

"Improving Working Conditions in the Readymade Garment Industry: Progress and Achievements" International Labour Organization (January 2016), online: International Labor Organization <http://www.ilo.org/dhaka/Whatwedo/Projects/WCMS_240343/lang-en/index.htm>

“International Trade Statistics 2007" World Trade Organization (2007), online: World Trade Organization < https://www.wto.org/english/res_e/statis_e/its2007_e/its2007_e.pdf>

“International Trade Statistics 2015" World Trade Organization (2015), online: World Trade Organization < https://www.wto.org/english/res_e/statis_e/its2015_e/its15_highlights_e.pdf>

Kolodner, Eric, "Transnational Corporations: Impediments or Catalysts of Social Development" United Nations Research Institute for Social Development (November 1994), online: United Nations <http://www.unrisd.org/80256B3C005BCCF9/(httpAuxPages)/ BFDE1D6D1B24C8FD80256B65004B6D57/\$file/OPWSSD5.pdf> 
Luebker, Malte, "Minimum Wages in the Global Garment Industry" International Labour Organization Regional Economic and Social Analysis Unit: Research Note (November 2014), online: International Labour Organization <http:/www.ilo.org/wcmsp5/groups/ public/---asia/---ro-bangkok/documents/publication/wcms_317002.pdf>

Mlachila, Montfort \& Yang, Yongzheng, "The End of Textile Quotas: A Case Study of the Impact on Bangladesh" International Monetary Fund Working Paper (2004), online: International Monetary Fund < https:/www.imf.org/external/pubs/ft/wp/2004/wp04108.pdf>

Moran, Theodore, "The United Nations and Transnational Corporations: A Review and a Perspective" United Nations Conference on Trade and Development (2009), online: UNCTAD <http://unctad.org/en/Docs/diaeiia200910a4_en.pdf >

“OECD Guidelines for Multinational Enterprises: 2011 Edition” Organization for Economic Cooperation and Development (2011), online: OECD <http://www.oecd.org/corporate/mne/ 48004323.pdf>

Rahman, Mustafizur, "Trade Benefits for Least Developed Countries: the Bangladesh Case" United Nations Department of Economic and Social Affairs (28 July 2014), online: United Nations <http://www.un.org/en/development/desa/policy/cdp/cdp_background_papers/ bp2014_18.pdf>

Report of the Special Representative of the Secretary-General on the Issue of Human Rights and Transnational Corporations and other Business Enterprises, John Ruggie, Guiding Principles in Business and Human Rights: Implementing the United Nations "Protect, Respect and Remedy” Framework, UNHRCOR, 17th Sess, UN Doc A/HRC/17/31, (2011)

Report of the Working Group on the Issue of Human Rights and Transnational Corporations and other Business Enterprises, UNHRCOR, 20th Sess, UN Doc A/HRC/20/29, (2012)

Ruggie, John, Promotion and Protection of all Human Rights, Civil, Political, Economic, Social and Cultural Rights, Including the Right to Development, UNHRCOR, 8th Sess, UN Doc A/ $\mathrm{HRC} / 8 / 5$, (2008)

Ruggie, John, Report of the Special Representative of the Secretary General on the Issue of Human Rights and Transnational Corporations and other Business Enterprises, UNHRCOR, 17th Sess, UN Doc A/HRC/17/31, (2011)

UNCTAD Secretariat, “The Least Developed Countries 1999 Report” United Nations Conference on Trade and Development (1999), online: United Nations Conference on Trade and Development <http://unctad.org/en/Docs/ldc1999_en.pdf> 


\section{OTHER SOURCES}

"12 Dead in Bangladesh Garment Factory Fire" Clean Clothes (1 August 2000), online: Clean Clothes $<$ https://archive.cleanclothes.org/newslist/129.html $>$

“About Us" Bangladesh Export Processing Zones Authority (15 February 2015), online: BEPZA $<$ http://www.epzbangladesh.org.bd/pages/details/about>

"About WRAP" Worldwide Responsible Accredited Production (2016), online: WRAP $<\mathrm{http}: / /$ www.wrapcompliance.org>

"Accord on Fire and Building Safety in Bangladesh" Accord on Fire and Building Safety in Bangladesh (13 May 2013), online: Accord <http://bangladeshaccord.org/wp-content/ uploads/2013/10/the_accord.pdf $>$

“Alliance for Bangladesh Worker Safety" Alliance for Bangladesh Worker Safety (2016), online: Alliance $<\mathrm{http}: / /$ www.bangladeshworkersafety.org $>$

Bain, Marc \& Avins, Jenni, “The Thing That Makes Bangladesh's Garment Industry Such a Huge Success Also Makes it Deadly" Quartz (24 April 2015), online: Quartz <http://qz.com/ 389741/the-thing-that-makes-bangladeshs-garment-industry-such-a-huge-success-alsomakes-it-deadly/>

"Bangladesh" European Commission (28 April 2016), online: European Commission $<\mathrm{http}: / /$ ec.europa.eu/trade/policy/countries-and-regions/countries/bangladesh/>

"Bangladesh Building Collapse Death Toll Passes 500" BBC News (3 May 2013), online: British Broadcasting Corporation $<$ http://www.bbc.com/news/world-asia-22394094>

"Bangladesh and The World Bank Working Together to End Extreme Poverty" The World Bank (27 October 2015), online: The World Bank: IBRD. IDA < http://www.worldbank.org/en/ news/press-release/2015/10/27/bangladesh-and-world-bank-working-together-to-endextreme-poverty>

Bangladesh Bureau of Statistics, online: Bangladesh Bureau of Statistics $<$ http:// www.bbs.gov.bd/PageWebMenuContent.aspx?MenuKey=363>

"Bangladesh GDP and Economic Data" Global Finance (12 March 2016), online: Global Finance $<$ https://www.gfmag.com/global-data/country-data/bangladesh-gdp-country-report $>$

"Bangladesh Mongla Cement Factory Kills Eight" BBC News (12 March 2015), online: British Broadcasting Company <http://www.bbc.com/news/world-asia-31849576> 
"Benchmarking the Competitiveness of Nicaragua's Apparel Industry" O'Rourke Group Partners LLC (April 2011), online: O'Rourke Group Partners $<$ http:// tradebridgeconsultants.com/documents/Nicaragua-Benchmarking-the-competitiveness-ofNicaraguas-Apparel-Industry.pdf/>

Berg, Achim, Hedrich, Saskia \& Tochtermann, Thomas, "Bangladesh: The Next Hot Spot in Apparel Sourcing?" McKinsey \& Company (March 2012), online: McKinsey \& Company $<$ http://www.mckinsey.com/industries/consumer-packaged-goods/our-insights/bangladeshthe-next-hot-spot-in-apparel-sourcing $>$

Berg, Achim, Hedrich, Saskia, Kempf, Sebastian \& Tochtermann, Thomas, "Bangladesh's Ready-Made Garments Landscape: The Challenge of Growth" McKinsey \& Company (November 2011), online: McKinsey \& Company $<$ https://www.mckinsey.de/sites/mck_files/ files/2011_McKinsey_Bangladesh.pdf>

Burke, Jason, "Bangladesh Garment Workers Suffer Poor Conditions Two Years After Reform Vows" The Guardian (22 April 2015), online: Guardian News and Media Limited <https:// www.theguardian.com/world/2015/apr/22/garment-workers-in-bangladesh-still-sufferingtwo-years-after-factory-collapse>

"Canadian Democracy \& Corporate Accountability: An Overview of Issues" The Democracy and Corporate Accountability Commission (2001), online: Canadian Democracy \& Corporate Accountability $<$ http://aix 1.uottawa.ca/ cforcese/other/commissionpaper.pdf $>$

Chen, Michelle, “A Western Company Could Finally Be Held Accountable for the Rana Plaza Disaster" The Nation (29 April 2016), online: The Nation Company $<\mathrm{https}: / /$ www.thenation.com/article/a-western-company-could-finally-be-held-accountable-for-therana-plaza-disaster/>

"Conventions" International Labour Organization (2012), online: ILO <http://www.ilo.org/dyn/ normlex/en/f?p=1000:12000:751417052845782::::P12000_INSTRUMENT_SORT:4>

"Conventions and Recommendations" International Labour Organization (2016), online: ILO $<$ http://www.ilo.org/global/standards/introduction-to-international-labour-standards/ conventions-and-recommendations/lang--en/index.htm>

"Corporate Social Responsibility" Global Affairs Canada (2016), online: Government of Canada: Global Affairs Canada <http://www.international.gc.ca/trade-agreements-accordscommerciaux/topics-domaines/other-autre/csr-rse.aspx?lang=eng\#CSR>

De Sam Lazaro, Fred, "Questions Linger a Year After Bangladesh's Garment Factory Collapse" PBS Newshour (9 April 2014), online: NewsHour Productions LLC <http://www.pbs.org/ newshour/updates/questions-linger-after-bangladeshs-garment-factory-collapse/> 
"Export Target of US \$50 Billion by 2021 set by Bangladesh RMG Sector" Apparel Resources (9 September 2015), online: Apparel Resources: Everything Sourcing < http://

news.apparelresources.com/trade-news/export-target-of-us-50-billion-by-2021-set-bybangladesh-rmg-sector/>

"Garment Workers Die in Bangladeshi Fire Alarm” Clean Clothes (1 August 2001), online: Clean Clothes <http://www.cleanclothes.org/news/2001/08/01/garment-workers-die-inbangladeshi-fire-alarm $>$

Greenhouse, Steven, "U.S. Retailers See Big Risk in Safety Plan for Factories in Bangladesh" The New York Times (22 May 2013), online: The New York Times <http:/www.nytimes.com/ 2013/05/23/business/legal-experts-debate-us-retailers-risks-of-signing-bangladeshaccord.html?_r=0>

Greenhouse, Stephen \& Clifford, Stephanie, "U.S. Retailers Offer Plan for Safety at Factories" The New York Times (10 July 2013), online: The New York Times <http://www.nytimes.com/ 2013/07/11/business/global/us-retailers-offer-safety-plan-for-bangladeshi-factories.html>

Hasan Abed, Fazle, "Bangladesh Needs Strong Unions, Not Outside Pressure" The New York Times (29 April 2013), online: The New York Times Company <http://www.nytimes.com/ 2013/04/30/opinion/bangladesh-needs-strong-unions-not-outside-pressure.html?_r=0>

Heitzman, James \& Worden, Robert, "Bangladesh: A Country Study" Federal Research Division: Library of Congress (1989), online: United States Government <http:// memory.loc.gov/master/frd/frdcstdy/ba/bangladeshcountr00heit/bangladeshcountr00heit.pdf>

Hoskins, Tansy, "Reliving the Rana Plaza Factory Collapse: A History of Cities in 50 Buildings, Day 22" The Guardian (23 April 2015), online: The Guardian <http://www.theguardian.com/ cities/2015/apr/23/rana-plaza-factory-collapse-history-cities-50-buildings $>$

Hossain, Farid, "Dozens Die in Fire at Bangladesh Factory" The Guardian (27 November 2000), online: The Guardian <http://www.theguardian.com/world/2000/nov/27/bangladesh>

International Council on Human Rights Policy, Beyond Voluntarism: Human Rights and the Developing International Legal Obligations of Companies (Versoix, CH: International

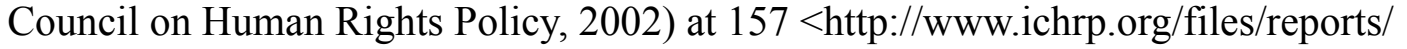
7/107_report_en.pdf>

"Interview with Jailed Rana Plaza Factory Owner Bazlus Samad Adnan" CBC The Fifth Estate (11 October 2013), online: CBC http://www.cbc.ca/fifth/blog/interview-with-jailed-ranaplaza-factory-owner-bazlus-samad-adnan> 
Jowell, Russell, "Statement Regarding the Collapse of the Rana Plaza Building in Bangladesh" Worldwide Responsible Accredited Production (24 April 2013), online: WRAP $<$ http:// www.wrapcompliance.org/documents/news/WRAP_Rana_Plaza_Statement.html>

Kabeer, Naila \& Mahmud, Simeen, "Rags, Riches and Women Workers: Export-Oriented Garment Manufacturing in Bangladesh" Women in Informal Employment: Globalizing and Organizing (January 2004), online: WIEGO < http://wiego.org/sites/wiego.org/files/ publications/files/Kabeer-Mahmud-Export-Oriented-Garment-Bangladesh.pdf $>$

Kamlani, Tarannum, “Made in Bangladesh” CBC The Fifth Estate (11 October 2013), online: CBC/Radio-Canada <http://www.cbc.ca/fifth/episodes/2013-2014/made-in-bangladesh>

Kaye, Leon, “U.S. Court Dismisses Rana Plaza Lawsuit” Triple Pundit (9 May 2016), online: Triple Pundit <http://www.triplepundit.com/2016/05/u-s-court-dismisses-rana-plaza-lawsuit/ \#>

Khalil, Tasneem, "18 Killed in Building Collapse” CNN (25 February 2006), online: CNN $<$ http://www.cnn.com/2006/WORLD/asiapcf/02/25/bangladesh.building.collapse/>

Kopun, Francine, “Bangladesh Factory Collapse: Loblaw to Audit Structural Safety of Suppliers' Buildings" The Star (2 May 2013), online: Toronto Star Newspapers Limited $<$ https:// www.thestar.com/business/2013/05/02/ bangladesh_factory_collapse_unions_put_pressure_on_loblaw_joe_fresh.html $>$

“Loblaw Will 'Vigorously Defend' Lawsuit Over Rana Plaza Factory Collapse” CBC News (30 April 2015), online: CBC/Radio-Canada <http:/www.cbc.ca/news/business/loblaw-willvigorously-defend-lawsuit-over-rana-plaza-factory-collapse-1.3055872>

"Legal Texts: The WTO Agreements" World Trade Organization, online: World Trade Organization < https://www.wto.org/english/docs_e/legal_e/final_e.htm>

"List of Least Developed Countries (as of 16 February 2016)" United Nations Department of Economic And Social Affairs Development Policy and Analysis Division Committee for Development Policy (16 February 2016), online: United Nations <http://www.un.org/en/ development/desa/policy/cdp/ldc/ldc_list.pdf>

"List of OECD Member Countries - Ratification of the Convention on the OECD" Organization for Economic Cooperation and Development (2016), online: OECD: Better Policies for Better Lives <http://www.oecd.org/about/membersandpartners/list-oecdmember-countries.htm> 
"List of Goods Produced by Child Labor or Forced Labor" Bureau of International Labor Affairs, United States Department of Labor (1 December 2014), online: United States Department of Labor <https://www.dol.gov/ilab/reports/pdf/TVPRA_Report2014.pdf $>$

Mackinnon, Mark \& Strauss, Marina, "Spinning Tragedy: The True Cost of a T-Shirt" The Globe and Mail (12 October 2013), online: The Globe and Mail Incorporated <http:// www.theglobeandmail.com/report-on-business/spinning-tragedy-the-true-cost-of-a-t-shirt/ article14849193/?page $=$ all $>$

"Member States" United Nations (2016), online: UN <http://www.un.org/en/member-states/>

Momen, Nurul, "Implementation of Privatization Policy: Lessons from Bangladesh" The Innovation Journal: The Public Sector Innovation Journal (2007), online: Innovation $<\mathrm{http}$ // www.innovation.cc/scholarly-style/momen_privatization4e.pdf>

Nguyen, Linda, "Loblaw Goes Global with Joe Fresh Stores" Global News (20 February 2014), online: Global News <http://globalnews.ca/news/1161347/loblaw-goes-global-with-joefresh-stores/>

"Pants and Shorts" Joe Fresh (2016), online: Loblaws Incorporated <https://www.joefresh.com/ $\mathrm{ca} />$

"Profile" Bureau Veritas (2016), online: Bureau Veritas Group <http://www.bureauveritas.com/ home/about-us>

"Rana Plaza" Rochon Genova (2016), online: Rochon Genova LLP $<$ http:// www.rochongenova.com/Current-Cases/Rana-Plaza.shtml>

"Rana Plaza Collapse: Dozens Charged with Murder" The Guardian (1 June 2015), online: Guardian News and Media Limited <https://www.theguardian.com/world/2015/jun/01/ranaplaza-collapse-dozens-charged-with-murder-bangladesh $>$

"Savar Tragedy: Factory Owner Surrenders, Sent to Jail" The Daily Star (9 May 2005), online: The Daily Star <http://archive.thedailystar.net/2005/05/09/d5050901033.htm>

Sebastio, Filippo, "Female Empowerment in the Bangladesh Garment Industry" International Growth Centre (18 November 2014), online: International Growth Centre $<\mathrm{http}: / /$ www.theigc.org/blog/female-empowerment-in-the-bangladeshi-garment-industry/>

"Securities Law \& Instruments: In the Matter of Loblaw Companies Limited and Provigo Inc" Ontario Securities Commission (17 December 2003), online: OSC <https:// www.osc.gov.on.ca/en/SecuritiesLaw_ord_20040102_2511_loblawcompanies.htm> 
Shaw, Hollie, "Class Action Suit Seeks \$2 Billion from Loblaw, Joe Fresh Over 2013 Bangladesh Garment Factory Collapse" Financial Post (30 April 2015), online: Financial Post $<$ http://business.financialpost.com/news/retail-marketing/class-action-suit-seeks-2billion-from-loblaw-joe-fresh-over-2013-bangladesh-garment-factory-collapse >

"Six Roasted Alive in Fire at Jamuna Spinning Mill in Gazipur, 2nd Ld" BDNews 24 (2 August 2006), online: BDNews24 <http://bdnews24.com/bangladesh/2006/02/08/six-roasted-alivein-fire-at-jamuna-spinning-mill-in-gazipur-2nd-ld $>$

Srivastava, Mehul \& Devnath, Arun, "Bangladesh's Paradox for Poor Women Workers: Low Wages and Hazardous Conditions Put Workers in Harm's Way” Bloomberg (9 May 2013), online: Bloomberg LP $<$ http://www.bloomberg.com/news/articles/2013-05-09/bangladeshsparadox-for-poor-women-workers $>$

Stiglitz, Joseph, “Globalism's Discontents" The American Prospect (4 January 2002), online: The American Prospect <http://prospect.org/article/globalisms-discontents $>$

Strauss, Marina, "Loblaw Calls on Industry to end 'Unacceptable Risk' in Bangladesh" The Globe and Mail (2 May 2013), online: The Globe and Mail Incorporated <http:// www.theglobeandmail.com/report-on-business/loblaw-calls-on-industry-to-endunacceptable-risk-in-bangladesh/article11676189/>

Strauss, Marina, "Loblaw Moves to Improve Safety at Bangladeshi Factories" The Globe and Mail (26 April 2013), online: The Globe and Mail Incorporated <http:// www.theglobeandmail.com/report-on-business/loblaw-moves-to-improve-safety-atbangladeshi-factories/article11563889/>

"Supply Chains Resources Hub" International Trade Union Confederation, online: ITUC $<$ http://www.ituc-csi.org/supply-chains-resources-hub?lang=en>

Supply Chain Risk Report: Child and Forced Labour in Canadian Consumer Products" World Vision: For Children. For Change. For Life (8 June 2016), online: World Vision Canada $<$ http://nochildforsale.ca/wp-content/uploads/2016/06/Child-and-forced-labourreport jun-08.pdf $\#>$

"Team" Shareholder Association for Research \& Education (2016), online: SHARE <http:// share.ca/about/team/kevin-thomas/\#>

"Textiles Monitoring Body (TMB): The Agreement on Textiles and Clothing" World Trade Organization (2016), online: WTO < https://www.wto.org/english/tratop_e/texti_e/ texintro_e.htm> 
Than, Ker, "Bangladesh Building Collapse Due to Shoddy Construction" National Geographic (26 April 2013), online: National Geographic Partners <http://news.nationalgeographic.com/ news/2013/13/130425-bangladesh-dhaka-building-collapse-world/>

"The Core International Human Rights Instruments and their Monitoring Bodies" United Nations Human Rights: Office of the High Commissioner (2016), online: UN OHCHR <http:// www.ohchr.org/EN/ProfessionalInterest/Pages/CoreInstruments.aspx>

“The WTO Agreements" World Trade Organization (2016), online: World Trade Organization $<$ https:/www.wto.org/english/thewto_e/whatis_e/inbrief_e/inbr03_e.htm>

"Three Tragedies Hit Bangladesh Factories in One Week, Leaving Scores Dead, Wounded" Clean Clothes (27 February 2006), online: Clean Clothes <http://www.cleanclothes.org/ news/2006/02/27/three-tragedies-hit-bangladesh-factories-in-one-week-leaving-scores-deadwounded $>$

“Timeline: Deadly Factory Accidents in Bangladesh" CBC News (9 October 2013), online: CBC/ Radio-Canada <http://www.cbc.ca/news2/interactives/timeline-bangladesh/>

"Toll Rise to 54 in Bangladesh Textile Fire" The New York Times (24 February 2006), online: The New York Times <http://www.nytimes.com/2006/02/24/world/asia/24iht-web. 0224bangla.html?_r=1\&>

"Trade Information: Membership and Employment" Bangladesh Garment Manufacturers and Exporters Association (22 February 2016), online: Bangladesh Garment Manufacturers and Exporters Association: Towards a Sustainable Garments Industry $<\mathrm{http}: / /$ www.bgmea.com.bd/home/pages/tradeinformation>

“Transnational Corporations" United Nations Conference on Trade and Development (2013), online: United Nations Conference on Trade and Development $<\mathrm{http}$ ://unctad.org/en/Pages/ DIAE/Transnational-corporations-(TNC).aspx>

Ullah, Anam, "Garment Industry in Bangladesh: An Era of Globalization and NeoLiberalization” Middle-East Journal of Business (April 2015), online: Middle-East Journal of Business $<\mathrm{http}: / /$ www.mejb.com/upgrade_flash/April2015/Neoliberalism.htm>

"Understanding the WTO: The Organization, Members and Observers" The World Trade Organization (2016), online: WTO $<$ https://www.wto.org/english/thewto_e/whatis_e/tif_e/ org6_e.htm>

"Unemployment, Total (\% of Labor Force)" The World Bank (2016), online: The World Bank Group: IBRD, IDA < http://data.worldbank.org/indicator/SL.UEM.TOTL.ZS> 
"UPDATE: RPCC Announce that Sufficient Funds Now Available to Complete Payments Under the Rana Plaza Arrangement" Rana Plaza Coordination Committee (8 June 2015), online: Rana Plaza Arrangement $<$ http://www.ranaplaza-arrangement.org/>. Stable URL $<$ http:// www.ranaplaza-arrangement.org/fund/donors/donors $>$

"Voluntary Codes Guide — What is a Voluntary Code?" Office of Consumer Affairs (9 March 2010), online: Government of Canada: Innovation, Science and Economic Development Canada <http://www.ic.gc.ca/eic/site/oca-bc.nsf/eng/ca00963.html>

Westwood, Rosemary, “What Does that \$14 Shirt Really Cost?” Maclean's (1 May 2013), online: Rogers Media <http:/www.macleans.ca/economy/business/what-does-that-14-shirt-really$\cos t />$

"What We Do" BRAC (2016), online: BRAC < http://www.brac.net/\#what_we_do >

Wolf, Martin, “Globalization in a Time of Transition” Financial Times (16 July 2013), online: FT $<$ http://www.ft.com/intl/cms/s/0/9545cd9e-ed3c-11e2ad6e-00144feabdc0.html\#axzz44LIF5rli>

Yardley, Jim, "Bangladesh Takes Step to Increase Lowest Pay" The New York Times (4 November 2013), online: The New York Times <http://www.nytimes.com/2013/11/05/world/ asia/bangladesh-takes-step-toward-raising-38-a-month-minimum-wage.html?_r=1>

Yunus, Mohammad \& Yamagata, Tatsufumi, “The Garment Industry in Bangladesh" Institute of Developing Economies (March 2012), online: Institute of Developing Economies: Japan External Trade Organization <http://www.ide.go.jp/English/Publish/Download/Report/2011/ pdf/410_ch6.pdf> 


\section{APPENDIX A}

\section{Rana Plaza, April 24, 2013}

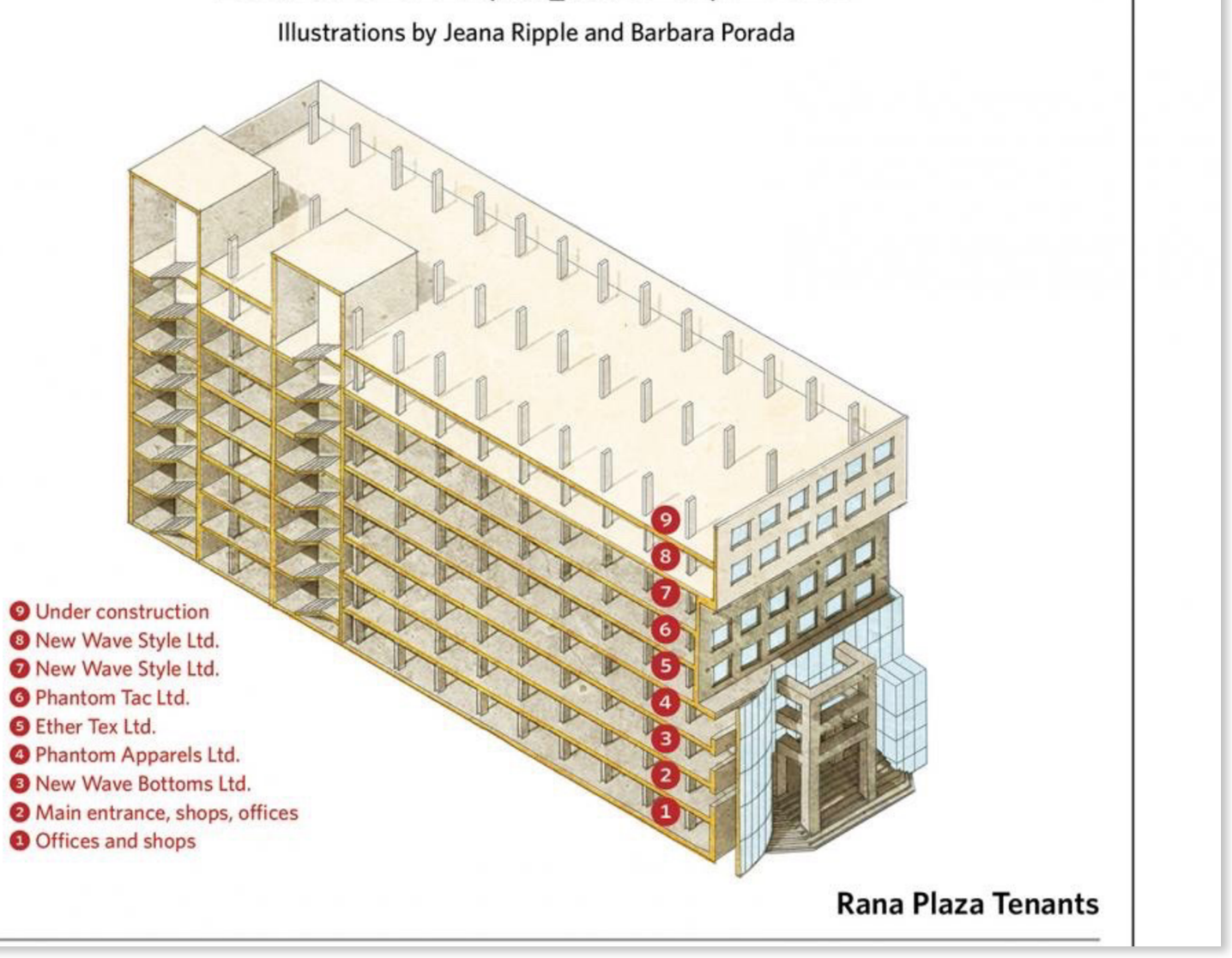

This picture reveals in explicit detail that New Wave, which was owned by Bazlus Samad Adnan and was fabricating garments for Loblaw Companies Limited, occupied floors 3, 7, \& 8. Floors $4,5, \& 6$ were engaged in fabricating garments for other manufacturers. Additionally, floor 9 was being constructed for Adnan so that he could accept more orders from Loblaw. ${ }^{1}$

${ }^{1}$ Jason Motlagh \& Atish Saha, "The Ghosts of Rana Plaza: In Bangladesh, One Year After the Worst Accident in the History of the Garment Industry, Recovery Remains a Fragile Process, Justice Seems Elusive, and Reform has a Long Way to Go" (2014) 90 Va Q Rev 44 at 67; It can also be accessed online through <http://www.vqronline.org/ reporting-articles/2014/04/ghosts-rana-plaza>. 


\section{APPENDIX B}

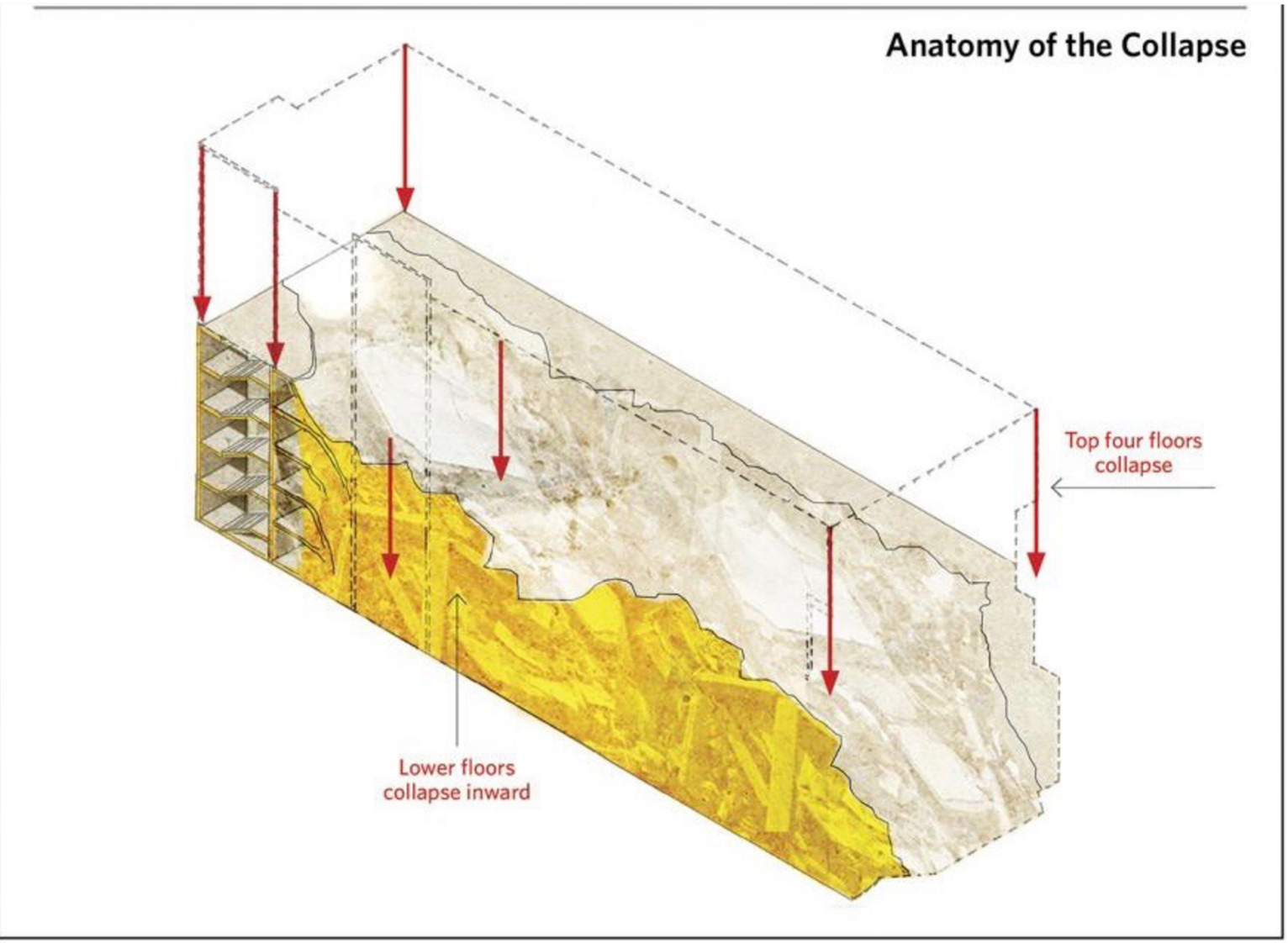

This picture reveals the process of the collapse. The top four floors (9th floor, under construction; 8th floor, New Wave; 7th floor, New Wave; and 6th floor, Phantom Tac) collapsed, which ultimately leveled the building. 


\begin{tabular}{|c|c|}
\hline \multicolumn{2}{|c|}{ APPENDIX C } \\
\hline Cost of fabricating a polo shirt in Bangladesh & $\$ 5.67$ \\
\hline $\begin{array}{c}\text { Cost of shipping a polo shirt from Bangladesh } \\
\text { to Canada }\end{array}$ & $\$ 1$ \\
\hline Total cost of polo shirt & $\$ 6.67$ \\
\hline $\begin{array}{l}\text { Minimum price the same polo shirt is sold in } \\
\text { Canada }\end{array}$ & $\$ 14$ \\
\hline $\begin{array}{l}\text { Wage an employee in Bangladesh receives for } \\
\text { making the same polo shirt }\end{array}$ & $12 \varnothing$ \\
\hline Minimum wage in Bangladesh & $\$ 38$ (has increased to $\$ 68$ as of late 2013 ) \\
\hline
\end{tabular}


APPENDIX D $D^{2}$

\begin{tabular}{|c|c|c|}
\hline $\begin{array}{c}\text { Sectors of GDP in } \\
\text { Bangladesh }\end{array}$ & $\begin{array}{c}\text { Composition of GDP in } \\
\text { Bangladesh }\end{array}$ & $\begin{array}{c}\text { Labor Force by Occupation } \\
\text { in Bangladesh }\end{array}$ \\
\hline Agriculture & $17.2 \%$ & $47 \%$ \\
\hline Industry (inclusive of RMG) & $28.9 \%$ & $13 \%$ \\
\hline Services & $53.9 \%$ & $40 \%$ \\
\hline
\end{tabular}

This graph clearly illustrates that even though $47 \%$ of Bangladesh's labor force was involved in agriculture, the sector only constitutes $17.2 \%$ of national GDP. Alternatively, while an infinitesimal $13 \%$ of the labor force is involved in industry, it accounts for $28.9 \%$ of national GDP. This speaks to why the Government of Bangladesh realized that industry was its future and would lead to greater economic prosperity than that of agriculture.

\footnotetext{
2 "Bangladesh GDP and Economic Data" Global Finance (12 March 2016), online: Global Finance <https:// www.gfmag.com/global-data/country-data/bangladesh-gdp-country-report>; Bangladesh Bureau of Statistics, online: Bangladesh Bureau of Statistics <http://www.bbs.gov.bd/WebTestApplication/userfiles/Image/GDP/ GDP_2014-15_Final.pdf> at 1 .
} 